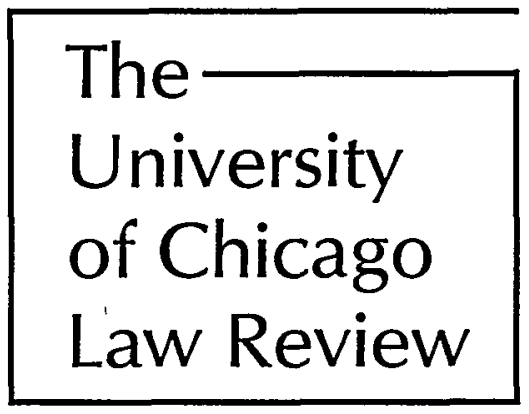

(C) 1994 by The University of Chicago

\title{
The Constitution in Congress: Substantive Issues in the First Congress, 1789-1791
}

\author{
David P. Currieł
}

Judicial review of legislative and executive action has been such a success in the United States that we tend to look exclusively to the courts for guidance in interpreting the Constitution. The stock of judicial precedents is rich, accessible, and familiar, but it does not exhaust the relevant materials. Members of Congress and executive officers, no less than judges, swear to uphold the Constitution, and they interpret it every day in making and applying the law. Like judges, they often engage in

$\dagger$ Edward H. Levi Distinguished Service Professor and Interim Dean, The University of Chicago Law School. The author wishes to thank the Kirkland \& Ellis Faculty Research Fund, the Mayer, Brown \& Platt Faculty Research Fund, the Morton C. Seeley Fund, the Raymond \& Nancy Goodman Feldman Fund, and the Sonnenschein Faculty Research Fund for financial support; Charlene Bangs Bickford, Kenneth R. Bowling, and Helen E. Veit of the First Federal Congress Project for access to hitherto unpublished reports of the debates; Kenneth Bowling, Gerhard Casper, Richard Posner, and Richard Ross for invaluable advice and encouragement; and Keith Garza for exemplary research assistance.

1 "[T]he whole business of Legislation," said Representative Theodore Sedgwick in 1791, "was a practical construction of the powers of the Legislature . . . " Gales \& Seaton, eds, 2 Annals of Congress 1960 (1791) ("Annals"). See generally Frank H. Easterbrook, Presidential Review, 40 Case W Res L Rev 905 (1989-90); Jefferson Powell, ed, Languages of Power: A Source Book of Early American Constitutional History xi-xii (Carolina Academic Press, 1991). Volumes 1 and 2 of the Annals of Congress appear in two separate compilations, one edited by Gales alone, the other edited by Gales and Seaton. Care must be taken to distinguish the sets, because pagination differs from one to the other. All cita- 
extensive and enlightening debates over the constitutional issues that confront them. Like judges, they also leave voluminous records of their deliberations-from statutes and legislative hearings, reports, and debates to presidential messages, proclamations, and opinions of the Attorneys General, to mention only a few.

The very profusion of this material means that one must often do a good deal of sifting to uncover the treasure. Yet that was equally true at Sutter's Mill, and here too there is plenty to be uncovered. At the least, legislative and executive records are apt to afford a useful preview of later judicial controversy, since courts rarely intervene before the other branches have made their decisions. Moreover, especially in the early days, many years would often pass before the courts were called upon to reexamine legislative or executive acts. Before 1800 nearly all our constitutional law was made by Congress or the President, and so was much of it thereafter. Indeed a number of constitutional issues of the first importance have never been resolved by judges; what we know of their solution we owe to the legislative and executive branches, whose interpretations have established traditions almost as hallowed in some cases as the Constitution itself.

Legislative and executive opinions respecting some of the great controversies are widely known. The President's right to remove executive officers and Congress's power to establish a bank $^{2}$ are two early examples. In the main, however, legislative and executive precedents are less familiar than judicial ones. The aim of this study is to begin to remedy that deficiency, in the conviction that both Congress and the Executive have a great deal to tell us about the Constitution.

New Hampshire, the decisive ninth state under Article VII, ratified the Philadelphia Constitution on June $21,1788 .^{3}$ Elec-

tions in this Article are to the Gales \& Seaton edition. The Annals themselves are incomplete; I have supplemented them where necessary with references to other contemporaneous accounts currently being collected in volumes 10-14 of the Documentary History of the First Federal Congress (Johns Hopkins, 1972-) ("Doc Hist"). For further discussion of the inadequacies of the Annals, see Charles F. Hobson, et al, 12 The Papers of James Madison 63-64 (Virginia, 1979) ("Madison Papers"); 13 Madison Papers at 6-8; James H. Hutson, The Creation of the Constitution: The Integrity of the Documentary Record, $65 \mathrm{Tex} \mathrm{L}$ Rev 1, 35-38 (1986).

2 See text accompanying notes 193-218.

3 See Roscoe R. Hill, ed, 34 Journals of the Continental Congress, 1774-1789 281 (US GPO, 1937) ("Journals"); John P. Butler, 5 The Papers of the Continental Congress 17741789658 (US GPO, 1978). 
tions were held pursuant to rules specified by the outgoing Confederation Congress, ${ }^{4}$ and the new House and Senate convened in New York on March 4, 1789. It took a month and more than one stern summons to produce a Senate quorum, ${ }^{5}$ and neither North Carolina nor Rhode Island had yet signed on. By April, however, both Houses were in business; and their business was to set up the government of the United States.

For the Constitution, as Chief Justice Marshall would later remind us, laid down only the "great outlines" of the governmental structure; ${ }^{6}$ translating the generalities of this noble instrument into concrete and functioning institutions was deliberately left to Congress. The task was one partly of interpretation and partly of interstitial creation, for the Framers had been too wise to attempt to regulate all the details themselves. Thus in a very real sense the First Congress was a sort of continuing constitutional convention, and not simply because so many of its members-James Madison, Oliver Ellsworth, Elbridge Gerry, Rufus King, Robert Morris, and William Paterson being only the most conspicuous examples-had helped to compose or to ratify the Constitution itself. ${ }^{7}$

On April 6 the votes of the presidential electors were counted before a joint session of both Houses, as Article II prescribed. ${ }^{8}$ In accord with that provision, each of the 69 electors had cast two votes. As expected, each had given one vote to George Washington; John Adams was second with 34 votes and thus became Vice-President. ${ }^{9}$ Acutely aware that everything he or Congress did would set a precedent, ${ }^{10}$ Washington urged the legislators to

4 34 Journals at 523 (Sept 13, 1788).

5 See 1 Annals at 15-16. Article I, \& 5 permits each House to authorize a number not constituting a quorum to compel the attendance of absent members, but since the Senate had never met before it had made no such authorization.

- M'Culloch $v$ Maryland, 17 US 316, 407 (1819).

7 See John C. Miller, The Federalist Era: 1789-1801 5 (Harper \& Brothers, 1960); Charles A. Beard, Economic Origins of Jeffersonian Democracy 99 (MacMillan, 1915). For invaluable biographical information about the members of the First and later Congresses, see generally the Biographical Directory of the United States Congress 1774-1989 (US GPO, bicentennial ed 1989).

8 US Const, Art II, $\S 1$, cl 3.

9 See 1 Annals at 17 . The remaining 35 votes were scattered among 10 candidates, of whom John Jay received the most with 9.

10 "I walk," Washington wrote on one early occasion, "on untrodden ground." Letter of George Washington to Catherine Macaulay Graham, Jan 9, 1790, in John C. Fitzpatrick, ed, 30 The Writings of George Washington 495, 496 (US GPO, 1939). See also Washington's letter of May 5, 1789, asking Madison to draft a response to the House's reply to his inaugural address: "As the first of every thing, in our situation will serve to establish a Precedent, it is devoutly wished on my part, that these precedents may be 
permit "no local prejudices or attachments, no separate views, nor party animosities" to distract them from laying the foundations of national policy "in the pure and immutable principles of private morality. "11 With that he left them to do their work; and work they did.

The First Congress determined its own procedures, established the great executive departments, and set up the federal judiciary. It enacted a system of taxation, provided for payment of Revolutionary debts, and erected a national bank. It provided for national defense, regulated relations with Indian tribes, and (in the Senate) advised the President on foreign affairs. It passed statutes respecting naturalization, patents and copyrights, and federal crimes. ${ }^{12}$ It regulated relations among existing states and admitted new ones while providing for the administration of territories and the establishment of a permanent seat of government.

In doing all this Congress left us an invaluable set of annotations to a surprising number of provisions of the Constitution, finding time along the way to propose not ten but twelve additional articles to improve the document itself. By the time the First Congress adjourned in 1791 the country had a much clearer idea of what the Constitution meant than when that body had first met in $1789 .{ }^{13}$

fixed on true principles." Id at 310-11. Madison echoed these sentiments in the debate over presidential removal: "The decision that is at this time made, will become the permanent exposition of the constitution ...." 1 Annals at 514.

111 Annals at 27-29. He did not mention Pareto optimality. Tsk, tsk.

12 Representative Hartley moved at one point during the First Congress that a committee be directed to bring in a bankruptcy bill as well, arguing that "the Constitution required that an act should be passed on the subject." 1 Annals at 1143-44 (emphasis added). Smith suggested that it would be better "to defer the business till the public debt should be funded, and banks established, without which it was difficult to conceive how arrangements could be made to facilitate the payment of debts, or the operation of such a law," and Hartley agreed. Id at 1144. For Maclay's argument in the Senate that the bankruptcy power applied only to debts of "the Trading part of the community," see 9 Doc Hist at 225. See also 2 Annals at 1816, postponing consideration of a report from the Secretary of State on weights and measures, id at 1781, pending the outcome of British and French efforts to agree on a new set of international standards. The report itself appears in Julian Boyd, ed, 16 The Papers of Thomas Jefferson 650 (Princeton, 1961) ("Jefferson Papers").

13 Historians have written extensively about the issues that confronted the First Congress. See, for example, Miller, The Federalist Era (cited in note 7); Forrest McDonald, The Presidency of George Washington (Kansas, 1974); Leonard D. White, The Federalists: A Study in Administrative History (MacMillan, 1948); Irving Brant, James Madison: Father of the Constitution, 1787-1800 (Bobbs-Merrill, 1950); James Thomas Flexner, George Washington and the New Nation (1783-1793) (Little, Brown, 1970); Dumas Malone, 2 Jefferson and His Time: Jefferson and the Rights of Man (Little, Brown, 1951); Forrest 
The present Article deals with substantive matters that came before the First Congress. The myriad questions of government structure that arose during the same period are the subject of a separate study. ${ }^{14}$

\section{TAXES AND TRADE}

\section{A. Tariffs and Tonnage}

No government can run without money, and the old Congress's dependence on contributions from the states had been a principal source of discontent with the Articles of Confederation. ${ }^{15}$ One of the central innovations of the Philadelphia Convention was the general federal tax power conferred by the first clause of Article I, \& 8: "The Congress shall have power to lay and collect taxes, duties, imposts and excises, to pay the debts and provide for the common defence and general welfare of the United States." "Direct" taxes were required to be apportioned among the states according to population; duties, imposts, and excises were to be uniform throughout the United States. ${ }^{16}$ Congress was forbidden to lay any tax or duty on articles exported from any state, to discriminate by any revenue or trade measure in favor of the ports of any one state, or for twenty years to impose a tax of more than ten dollars a head on the importation of slaves. ${ }^{17}$

Congress thus had a wide choice of means for supporting the operations of the new Government. It decided to rely principally on customs duties on imported goods and tonnage duties on foreign and domestic vessels. ${ }^{18}$

McDonald, Alexander Hamilton: A Biography (W.W. Norton, 1979).

14 A companion piece to this Article, dealing with these issues of government structure in the First Congress, will appear in Volume 1994 of The University of Chicago Law School Roundtable.

15 See Articles of Confederation, Art VIII, in 1 Stat 4, 6 (July 9, 1778); Joseph Story, Commentaries on the Constitution of the United States §§ 123-25 at 96-98 (Carolina Academic Press, 1987) (first published 1833); Merrill Jensen, The New Nation: A History of the United States During the Confederation, 1781-1789 407-21 (Knopf, 1950).

16 US Const, Art I, § 2, cl 3; Art I, § 9, cl 4; Art I, § 8, cl 1 .

17 Art I, \& 9, cls 1, 5, \& 6. Article I, \& 7, cl 1 required "All bills for raising revenue" to originate in the House of Representatives but permitted the Senate to "propose or concur with amendments as on other bills."

181 Stat 24 (July 4, 1789) (tariffs); 1 Stat 27 (July 20, 1789) (tonnage). Customs duties had been the basis of the Confederation Congress's 1783 proposal for federal taxation, which, according to Madison, had "received, generally, the approbation of the several States...." 1 Annals at 107. To prevent interference with commerce or with federal revenue, Article I, $\S 10$ forbade the states to impose tonnage duties or tariffs 
The most striking feature of the tariff law was the candid admission in its first section that its purposes included not only the support of government and the payment of debts but also "the encouragement and protection of manufactures." In April, 1789 , as the House began debating the revenue question, it received a petition from a long list of Baltimore tradesmen complaining of the tendency of their fellow citizens to fritter away the nation's wealth "in the purchase of those articles, from foreigners, which our citizens, if properly encouraged, were fully competent to furnish" and urging Congress to "impos[e] on all foreign articles, which can be made in America, such duties as will give a just and decided preference to the[ ] labors [of American artisans] and [] discountenanc[e] that trade which tends so materially to injure them, and impoverish their country."20

These sentiments found many adherents in the House. Thomas Fitzsimons of Pennsylvania began by proposing specific duties on a long list of imported items from beer to nuts with the avowed purpose, among others, "to encourage the productions of our country, and protect our infant manufactures." ${ }^{\prime 21}$ Hartley enthusiastically agreed, ${ }^{22}$ Madison conceded that free trade was not an absolute principle, ${ }^{23}$ and other members scrambled for a piece of the action. Clymer sought protection for steel and paper, ${ }^{24}$ Moore and Heister for hemp, ${ }^{25}$ Carroll for glass, ${ }^{26}$ Bland and Parker for Virginia coal. ${ }^{27}$ Fisher Ames made quite a touching little oration on the virtues of cottage industries while advocating a protective tariff on nails. ${ }^{28}$ Roger Sherman pleaded for

("except what may be absolutely necessary for executing [their] inspection laws") "without the consent of the Congress." The purpose and operation of this provision were illustrated in August, 1790, when Congress approved a federal statute consenting to tonnage duties imposed by three states for navigation improvements-the establishment of port wardens in Maryland and the removal of obstructions from the Savannah River-that Congress had declined to finance out of the federal treasury. 1 Stat 184 (Aug 11, 1790); William Maclay, Diary (Dec 28, 1790), in 9 Doc Hist at 349.

19 Stat at 25.

${ }_{20} 1$ American State Papers (Finance) 5 (Gales \& Seaton, 1832). See also the similar petition from New York manufacturers. Id at 9.

211 Annals at 110-11. See also id at 150 (making a special plea for high duties to encourage the manufacture of malt liquor).

${ }^{22}$ Id at 114-15.

${ }^{23}$ Id at 115-19.

24 Id at 153-54 (steel), 174 (paper).

25 Id at 158.

26 Id at 174 .

27 Id at 177.

${ }^{28}$ [I] $\mathrm{t}$ has become usual for the country people in this State to erect small forges in their chimney corners, and in winter, and on evenings when little other work could 
a six-cent tariff on manufactured tobacco on the express ground that the duty ought to amount to a prohibition, and he got it. ${ }^{29}$

There were objections to several of these suggestions, ${ }^{30}$ but no one denied that Congress could constitutionally impose tariffs to stimulate domestic production, and it did so. ${ }^{31}$ Fitzsimons suggested a plausible basis for this authority in urging a discriminatory duty on bohea tea "not only as a revenue but as a regulation of a commerce highly advantageous to the United States." Our budding trade with China and India was clearly "commerce," and higher duties on goods imported in foreign vessels would encourage American shipping. ${ }^{33}$ Generalizing Fitzsimons's suggestion, $\S 5$ of the statute provided a $10 \%$ discount on all customs charges for imports carried by American vessels. ${ }^{34}$

Fitzsimons's argument that differential duties to promote American shipping constituted a regulation of foreign commerce suggested two interesting conclusions respecting the commerce power. First, a measure could qualify as a regulation of commerce even though it took the shape of a tax; not form but purpose and effect were determinative. ${ }^{35}$ Second, the power to regu-

be done, great quantities of nails were made even by children; perhaps enough might be manufactured in this way to supply the continent.

Id at 163. See also id at 164.

29 Id at 174; I Stat at 25.

3o Various members suggested that high duties on hemp would be detrimental to rope manufacturers and to the shipping business. 1 Annals at 158-62. Bland opposed the inclusion of nails as unfair to the South, since the Northern states made only enough nails for their own consumption. Id at 163. Madison urged restraint both because he thought there should be a presumption of free trade and because he was afraid disputes over particular objects of protection might delay the crucial business of financing the Government. Id at 115-19. Many years later, Madison would emphatically argue that the power to regulate commerce included the power to impose protective tariffs. See Letter of James Madison to Joseph C. Cabell, Sept 18, 1828, in Gaillard Hunt, ed, 9 The Writings of James Madison 316-40 (Putnam, 1910).

I1 "In its final form, the tariff of 1789 represented a compromise between the advocates of high protective duties and those who favored a tariff for revenue only.... [S]pecific duties ranging as high as $\mathbf{5 0}$ per cent were levied upon steel, ships, cordage, tobacco, salt, indigo, cloth, and so on." Miller, The Federalist Era at 15 (cited in note 7).

${ }^{32} 1$ Annals at 147.

33 Id at $147-48$.

34 1 Stat at 27.

3s For recognition in the Convention of the impracticability of distinguishing between commercial regulations and revenue measures, see Max Farrand, 2 The Records of the Federal Convention of 1787276 (Yale, revised ed 1937) ("Convention Records") (summarizing Madison's views). Later applications of Fitzsimons's principle include the Head Money Cases, 112 US 580, 595 (1884) (holding the requirement that duties be uniform inapplicable to a charge imposed on the landing of passengers from abroad on the ground that the exaction was not a tax but a regulation of commerce), Henderson $v$ Mayor of the City of New York, 92 US 259, 273-74 (1876) (striking down a similar state law as impinging on 
late commerce included the power to restrict it. In the immediate context this was hardly surprising, since one justification for giving Congress authority to regulate foreign commerce had been to permit it to retaliate against and therefore to deter foreign restrictions. ${ }^{36}$ But the First Congress's decision with respect to foreign commerce also seemed likely to affect the interpretation of the parallel clause regarding commerce among the several states, though the specific reason for giving this latter authority to Congress had been to enable it to remove obstacles to freedom of trade. ${ }^{37}$

The Commerce Clause argument also supported a second major feature of the tax system adopted by the First Congress: tonnage duties that discriminated sharply between American and foreign vessels. Ships built in the United States and owned by U.S. citizens were to pay six cents per ton per year. Ships built here but owned by foreigners were to pay thirty cents per ton, and all others fifty, each time they entered an American port. ${ }^{38}$ Madison expressly supported discriminatory tonnage duties on the ground that they would encourage American shipping, thus bringing them within the umbrella of the Commerce Clause as Fitzsimons had construed it. ${ }^{39}$

the federal power to regulate foreign commerce), and Bailey $v$ Drexel Furniture Co. (the Child Labor Tax Case), 259 US 20, 38-39 (1922) (striking down a federal tax as an effective regulation of child labor). See also David P. Currie, The Constitution in the Supreme Court: The First Hundred Years, 1789-1888 (Chicago, 1985) ("The First Hundred Years") at 431-32 (Head Money Cases), 405-08 (Henderson); David P. Currie, The Constitution in the Supreme Court: The Second Century, 1888-1986 173 (Chicago, 1990) ("The Second Century").

${ }^{36}$ See Federalist 11 and Federalist 22 (Hamilton), in Jacob E. Cooke, ed, The Federalist Papers 65, 135 (Wesleyan, 1961); Madison's Preface to the Debates in the Convention of 1787, in Farrand, 3 Convention Records at 539, 547.

${ }^{37}$ In support of this view see Farrand, 3 Convention Records at 542, 547-48; H.P. Hood \& Sons $v$ Du Mond, 336 US 525, 539 (1949). This issue was to divide the Court over 100 years later in the interstate context. See the various opinions in Champion $v$ Ames (The Lottery Case), 188 US 321, 355, 371-72 (1903), and in Hammer v Dagenhart, 247 US 251, 272, 277 (1918). See also The Second Century at 28, 96-98.

${ }_{38} 1$ Stat at 27-28 \& 1 (July 20,1789). Representative Bland argued at one point that any tonnage tax laid on ships traveling between ports in the United States would offend Art 1, \& 9, cl 5's provision that "vessels bound to, or from, one State" not "be obliged to enter, clear, or pay duties in another." More thoughtful colleagues pointed out that this language had been meant to preclude the exaction of tribute by a third state, not to exempt the coasting trade from such requirements altogether. See Daily Advertiser (May 5, 1789), New York Daily Gazette (May 5, 1789), Gazette of the United States (May 6, 1789); all in 10 Doc Hist at 408-11.

${ }^{39} 1$ Annals at 196-97. See also Madison's letter to George Nicholas, July 5, 1789, in 12 Madison Papers at 279, 280 (cited in note 1) ("a navigation act under the name of duties on tonnage"). Madison and others also defended high duties on British vessels (as well as a preference for French ships that was not adopted) on the ground of retaliation 
Congress would need to take a further step to find a commerce-power justification for duties designed to promote production, since neither agriculture nor industry was commerce within the ordinary meaning of the term. ${ }^{40}$ In one sense this step was not difficult to take, since any protective tariff restricts commerce itself by increasing the price of exchange; but acceptance of this position would mean that Congress could regulate foreign commerce in order to encourage conduct it presumably could not regulate directly. That in itself would be a significantly broad interpretation of congressional power, and it would later be hotly disputed, ${ }^{41}$ but it was less threatening to reserved state powers than the alternative explanation that the essentially unlimited tax power might similarly be used for ulterior ends. ${ }^{42}$

Many of the members who spoke during the debate on the tariff and tonnage laws seemed to think it appropriate to use the tax power itself for the promotion of goals unrelated to revenue. Few of the advocates of protection for domestic producers mentioned the commerce power. Ames said nothing about commerce in urging high tariffs for certain imports from Rhode Island in order to coerce that refractory state into joining the new Union. ${ }^{43}$ Fitzsimons himself, the exponent of the Commerce

against British measures obstructing our own shipping-which Abraham Baldwin of Georgia insisted had been the whole point of the Annapolis and Philadelphia Conventions. 1 Annals at 184-96. In addition, one of Madison's reasons for encouraging American shipping was to facilitate eventual establishment of a Navy, and thus the discrimination might also be justified as necessary and proper to Congress's authority "to provide and maintain a navy.” US Const, Art I, § 8, cl 13.

to See Marshall's definition in Gibbons $v$ Ogden, 22 US 1, 189 (1824) ("Commerce . . . is something more [than traffic]: it is intercourse."); United States v E.C. Knight Co., 156 US 1, 12 (1895) ("Commerce succeeds to manufacture, and is not a part of it."). See also Carter $v$ Carter Coal Co., 298 US 238, 297-310 (1936) (mining); The Second Century at 22, 223-24.

11 See The Lottery Case, 188 US at 365; Dagenhart, 247 US at 276; United States $v$ Darby, 312 US 100, 115-16 (1941) (overturning Dagenhart); The Second Century at 28, 9698, 238. Congress's acceptance of Sherman's prohibitive duty on manufactured tobacco products, see text accompanying note 29, suggests the further conclusion that the power to regulate commerce includes the power to forbid it-another important issue at stake in The Lottery Case, 188 US at 354-62. See also $\& 40$ of the 1789 statute providing for enforcement of the tariff law, 1 Stat 29, $48-49$ (July 31, 1789), which generally forbade the importation of goods subject to duty "in any other manner than by sea, [ ]or in any ship or vessel less than thirty tons burthen," evidently on the ground that this prohibition (or regulation) was necessary and proper to the collection of revenue.

12 See McCray $v$ United States, 195 US 27 (1904); The Child Labor Tax Case, 259 US at 20; The Second Century at 30, 173-74.

43 Ames "just stated that these articles were imported in considerable quantities from a neighboring State that had not yet adopted the constitution; and, perhaps, said he, our political situation is such as to make some regulation on this head necessary." 1 Annals at 162-63. Pressure on Rhode Island might conceivably have been defended as necessary and 
Clause thesis, bolstered his plea for high duties on liquor with an argument based entirely on health and morals: If the result was to discourage the consumption of alcoholic beverages, so much the better, because alcohol was "a luxury of the most mischievous kind." Finally, in adopting a duty on tobacco products that had explicitly been justified as a prohibition, Congress seemed to lend strength to the extreme position that taxes might be levied even when they served no revenue purpose at all.

Of course, as Justice Robert Jackson would later observe, economic incentives are inseparable from taxation: "[A]ll taxation has a tendency . . . to discourage the activity taxed. ${ }^{.45}$ Indeed, so far as the text is concerned, Article I could easily be read to permit Congress to levy taxes not only to pay the debts and provide for defense but also to promote the general welfare-in other words, for any reason that is good for the nation as a whole. On the other hand, indifference to the purpose and effect of measures cast in the form of taxes could obliterate the limitations on federal regulatory powers that were implicit in the initial enumeration and confirmed by the First Congress in proposing the Tenth Amendment. ${ }^{46}$

Because all the incentive provisions of the tariff and tonnage laws can be explained on the narrower ground that they effectively regulated interstate or foreign commerce, neither of these statutes proves that the legislators believed they could accomplish by taxation that which they could not do directly under the Commerce Clause. ${ }^{47}$ At the very least, however, they demon-

proper to protection of trade or revenues, to the conduct of foreign affairs, or even to the admission of additional states. See also text accompanying notes 347-70.

41 Annals at 204. See also id at 111 (noting that several items had been included in his initial list of specific duties in order to discourage their use). Madison made a similar argument in advocating the excise tax on whiskey that Congress adopted in 1791. See Daily Advertiser (Jan 15, 1791); text accompanying notes 48-68.

${ }_{45}$ United States $v$ Kahriger, 345 US 22, 35 (1953) (Jackson concurring).

16 "The powers not delegated to the United States by the Constitution, nor prohibited by it to the States, are reserved to the States respectively, or to the people." US Const, Amend X. See also M'Culloch $v$ Maryland, 17 US at 405. "[S]hould Congress, under the pretext of executing its powers, pass laws for the accomplishment of objects not entrusted to the government; it would become the painful duty of this tribunal, should a case requiring such a decision come before it, to say that such an act was not the law of the land." Id at 423.

${ }^{47}$ A provision in the act next to be discussed, however, did seem difficult to explain on any other basis. The excise on domestic liquors discriminated against beverages made from foreign materials, apparently to encourage local production. See 1 Stat 199, 202-03 $\$ \S 14-15$ (March 3, 1791). Though foreign materials must be imported before they can be turned into domestic whiskey, it might be stretching things to call this discrimination a regulation of commerce. 
strate that the First Congress took a broad view of the purposes for which it could regulate commerce; and those who would later argue that the tax power could be exercised only for revenue purposes would have a good deal of explaining to do.

\section{B. Whiskey}

Before Congress had been in business two years, it felt obliged to tap additional sources of revenue. ${ }^{48}$ As several speakers had emphasized during the 1789 debates, there were limits to how high customs duties could be raised without provoking widespread smuggling. ${ }^{49}$ Convinced that direct taxation would be contrary to the sentiments of the majority of the people, Madison accordingly proposed an excise on the domestic production of ardent spirits as the least objectionable option. ${ }^{50}$

Whiskey producers were not so sure, and as usual some of their arguments took constitutional shape. Jackson objected that the burden of the tax fell unequally on the South, which had "no breweries or orchards to furnish a substitute" for whiskey. ${ }^{51}$ Hugh Williamson of North Carolina tied this argument to Article I's requirement that excises be uniform throughout the United States and urged the House to equalize them, by proposing a tax on beer and cider. ${ }^{52}$

Similar arguments had been raised and rejected in the tariff debate, ${ }^{53}$ and they were rejected again as the whiskey tax was adopted. ${ }^{54}$ Since the tariffs could be justified as regulations of

4 The reason was to finance the payment of interest on state debts that Congress had assumed in 1790. See Hamilton's second report to the House of Representatives on public credit, Dec 13, 1790, in Harold C. Styrett and Jacob E. Cooke, eds, 7 The Papers of Alexander Hamilton 225, 226 (Columbia, 1963) ("Hamilton Papers"). For a discussion of the assumption controversy see text accompanying notes 179-92.

49 See, for example, 1 Annals at 200-01 (Rep Boudinot).

so 2 Annals at 1894.

s1 Id at 1890 .

52 Id at 1906-07. See also id at 1908 (Rep Parker).

63 See 1 Annals at 163 (Rep Bland) (arguing that a duty on nails would impose an unequal burden on the South because the Northern states manufactured their own); id at 170 (Rep Madison) (conceding the importance of a fair distribution of actual burdens by insisting that although Westerners would bear a disproportionate share of the salt tax it was "almost the only tax they will have to pay"). Neither Bland nor Madison expressly invoked the uniformity provision in this debate. See also the related argument of Representative Laurance, id at 184-85, that tonnage duties would increase the price of exports and thus constituted an export tax forbidden by Art I, $\S 9$. Parker seemed to echo this last contention in suggesting that the whiskey tax was "not any thing better than a tax on exports." Daily Advertiser (Jan 15, 1791).

54 1 Stat at 202-03 §§ 14-15. 
commerce, rejection of the inequality argument in that context might be explained on the unappetizing ground that Congress could evade the uniformity requirement by invoking some power other than that of taxation. ${ }^{55}$ No such argument was available, however, in the case of the whiskey excise; Congress seems to have concluded both that the Constitution required only geographical uniformity (as suggested by the phrase "uniform throughout the United States") and that the tax was uniform because it was nondiscriminatory on its face.

To require that the actual burden of taxation be distributed equally throughout the nation would have posed formidable accounting difficulties, but Justice Nelson's later example of a New York tax impartially imposed on domestic and out-of-state cotton suggests the possibilities of abuse invited by limiting the inquiry to facial discrimination. ${ }^{56}$ We had by no means heard the last of arguments that various constitutional guarantees required de facto as well as de jure equality. ${ }^{57}$

Other objections to the whiskey tax implicated provisions of the new Bill of Rights, which Congress had proposed in 1789 and which was ratified the same year the excise was adopted. Parker zeroed in on the mode of collecting the tax, which he argued would "let loose a swarm of harpies who... [would] range through the country, prying into every man's house and affairs." ${ }^{\text {"58 }}$ The modern reader will take this argument as a reminder to measure the enforcement provisions of the statute against the Fourth Amendment's prohibition of unreasonable searches and seizures.

The act's enforcement provisions are quite revealing in this regard, for in addition to authorizing the issuance of warrants to search any place where spirits were suspected of being fraudulently concealed, ${ }^{59}$ it empowered revenue agents to enter any registered distillery or warehouse to sample and measure the inventory, without any ground for suspicion and without procuring a warrant. ${ }^{60}$ Whether it was the regulated nature of the business or the voluntary act of distilling or storing liquor in the

${ }^{65}$ See Head Money Cases, 112 US at 595; The First Hundred Years at 431-32.

${ }^{56}$ Woodruff $v$ Parham, 75 US 123, 145-46 (1868) (Nelson dissenting); The First Hundred Years at 337.

${ }^{57}$ See, for example, Washington $v$ Davis, 426 US 229 (1976); The Second Century at 488-93.

ss 2 Annals at 1891-92.

69 1 Stat at $207 \S 32$.

60 1 Stat at $206 \$ 29$. 
face of the registration and inspection provisions that made this requirement reasonable, no one bothered to say, but Congress evidently thought there was no constitutional problem. ${ }^{61}$

Jackson perceived a distinct threat in the dreaded host of federal tax collectors and proposed to meet it by adding a clause "to prevent Inspectors, or any officers under them, from interfering, either directly or indirectly, in elections, further than giving their own votes." ${ }^{2}$ Sherman and Livermore made clear that the objection was to electioneering by federal agents whose duties would afford them "such a knowledge of persons and characters, as will give them great advantages, and enable them to influence elections to a great degree. ${ }^{\prime 33}$ Jackson added that his proposal was made more imperative by "the dangerous influence that some future Presidents would acquire, by virtue of the power which [they] will possess of removing these officers. ${ }^{n 64}$

John Vining of Delaware responded that Jackson's proposal was unconstitutional, as it would deprive revenue officers of the right "of speaking and writing their minds." Maryland's Joshua Seney replied that no rights would be infringed because it "would be optional to accept the offices or not,"66 but Jackson's motion to muzzle the revenuers was decisively rejected. ${ }^{67}$

Thus the First Congress gave us a concise but cogent preview of the arguments that were to be made many years later with respect to the constitutionality of the Hatch Act. ${ }^{68}$ While there were plenty of other objections to stripping civil servants of rights fundamental to the operation of republican government, Vining provided us at the outset with powerful ammunition

61 See also $\S \S 23 \& 24$ of the 1789 statute providing for the collection of tariff and tonnage duties, 1 Stat at 43 , authorizing customs officers without warrant to "open and examine" packages "on suspicion of fraud" and "to enter any ship or vessel" suspected of concealing goods subject to duty but requiring a warrant to search buildings under the same conditions. A supplemental collection law adopted the next year went even further, authorizing customs officers to board and inspect any vessel entering the United States or within four leagues of the coast, without requiring even suspicion of any wrongdoing. 1 Stat 145, $175 \& 64$ (Aug 4, 1790). As acts almost contemporaneous with the proposal of the Fourth Amendment, these provisions too provide some evidence of what Congress itself thought constituted an unreasonable search.

62 Annals at 1924-25.

63 Id at 1925.

of Id.

os Id. See also Ames's suggestion that Jackson's proposal would "muzzle the mouths of freemen, and take away the use of their reason." Id at 1926.

so Id.

67 Id at 1927.

68 See United Public Workers v Mitchell, 330 US 75 (1947); The Second Century at 355; United States Civil Service Commission v Letter Carriers, 413 US 548 (1973). 
based on the speech and press guarantees that Congress itself had recently proposed.

\section{Ship Licensing}

As we have seen, one argument in favor of protective tariffs was that they fell within Congress's power to regulate commerce. The First Congress did other interesting things under the commerce power as well.

Perhaps the best-known commercial regulation of the First Congress was the 1789 law providing for registration or enrollment of ships belonging to citizens of the United States. ${ }^{69}$ There was no requirement that ships be either registered or enrolled, but a registered or enrolled vessel was entitled to all privileges granted to U.S. vessels by federal law. ${ }^{70}$ Upon payment of tonnage duties and the posting of security against illicit trade or commerce, the owners of registered or enrolled vessels might obtain licenses to engage in the bank or whale fisheries or in trade between different customs districts within the United States. There was no requirement that a license be obtained, either, but unlicensed vessels of twenty tons or more engaging in these activities were subject to the same tonnage, and fees, as foreign ships or vessels. ${ }^{\text {11 }}$

This section was the predecessor of the licensing provision that Chief Justice Marshall would later invoke in striking down a state steamboat monopoly in Gibbons $v$ Ogden. ${ }^{72}$ The Annals reveal no recorded debate on the 1789 statute. Congress evidently was convinced that a regulation of transportation was a regulation of commerce, and Marshall relied heavily on Congress's view in upholding federal licensing: "[T]his power has been exercised from the commencement of the government . ..."73

None of the provisions of the 1789 Act was expressly limited to vessels engaged in commerce with foreign nations or among the several states. ${ }^{74}$ Possibly Congress thought that licensing of all ships owned by U.S. citizens was necessary and proper to the

691 Stat 55 \& 1 (Sept 1, 1789).

${ }^{70}$ Id at 60-61 $\S 22$.

71 Id at $61 \S 23$.

72 US 1 (1824).

73 Id at 190.

74 The license and enrollment provisions applied only to vessels traveling between districts or engaged in the "bank or whale fisheries," but several states contained more than one district, see 1 Stat at 29-35, and fishing on the high seas does not always involve contact with other countries or states. 
enforcement of import duties or to the collection of the tonnage taxes that were assessed even against local vessels; perhaps Congress simply overlooked the possibility that some ships subject to the law might be engaged in purely local commerce. In any event, the text and context of the licensing provision strongly suggested that its purpose was to facilitate the collection of duties, not to confer a right to engage in interstate or foreign trade. The later statute from which Marshall drew the opposite conclusion was similar in every relevant respect. ${ }^{75}$

\section{Inspection Laws}

In January 1790, Representative Sedgwick moved that a committee be appointed to explore means "to encourage the exports of the United States, and to guard against frauds in the same." The export of inferior goods, he explained, had so "injured the reputation of the United States" that legislation was needed, and Congress had power to enact it under the Commerce Clause. The ninth section of Article I, he added, forbade Congress only to tax exports, not to regulate them; and the tenth section confirmed the authority of Congress by empowering it to revise and control state inspection laws. ${ }^{77}$

Sedgwick did not say just what sort of legislation he had in mind, but he was on sound ground in suggesting that exports were subjects of foreign commerce susceptible to federal regulation. The argument that the power to regulate included the power to impose exactions that looked like taxes, strongly advanced during the tariff debates, raised the question whether the ban on export taxes ought to apply to some regulations as well; but it did not require the improbable conclusion that exports were wholly beyond the reach of a body expressly authorized to regulate commerce with other nations. Though the immediate effect of federal regulation might be to restrict the export of inferior items, its ultimate goal was to promote commerce; and in any event the

73 See 1 Stat 305 (Feb 18, 1793); The First Hundred Years at 171-72. Thus the licensing law illustrates once again the intimate relation between Congress's powers to tax and to regulate commerce. The protective tariff was an example of a tax imposed for regulatory purposes; ship licensing was an example of regulation imposed to promote the collection of taxes. See also 1 Stat 145, $175 \S 62$ (Aug 4, 1790), authorizing the President to build as many as ten "boats or cutters ... to be employed for the protection of the revenue, that is, as necessary and proper to the collection of duties.

761 Annals at 1143.

77 Id at 1142. 
tariff debate had suggested that the purpose of a commercial regulation was immaterial to its validity. ${ }^{78}$

Two months afterward, apparently in response to Sedgwick's proposal, Congress enacted a statute directing federal customs officials not to authorize any vessel to leave port without complying with state inspection laws. ${ }^{79}$ Given the understanding that transportation was trade, to restrict the movement of ships was to regulate commerce. Like the licensing law, however, this statute was not expressly limited to vessels sailing to other states or nations. Furthermore, in contrast to the licensing and registration provisions, it could hardly be thought necessary and proper to the collection of federal taxes, since its immediate purpose was to enforce state law $^{80}$ in the ultimate interest of promoting trade.

The constitutional difficulty, however, went deeper. Even with respect to ships that were engaged in interstate or foreign commerce, it was not obvious that Congress could provide for federal enforcement of state law. Executing that law, Livermore argued, was a matter for the states themselves; the bill was an unconstitutional interference with the powers of the respective states. ${ }^{81}$

In two respects the threat to state interests was less than that posed by the tariff law. Not only was the ultimate purpose of the inspection provision the irreproachable goal of removing obstructions to commerce; in addition, while the tariff law contained provisions intended to discourage conduct permitted by state law, the inspection statute was designed to help the states carry out their own policies. ${ }^{82}$ Nevertheless, both the provisions of the Judiciary Act for exclusive federal jurisdiction over certain classes of cases $^{83}$ and the traditional principle that one sovereign will not execute the penal laws of another ${ }^{84}$ suggest that on occasion a sovereign might legitimately object to officious assistance in enforcing its own laws. Livermore seemed to be suggesting an implicit limitation somewhat akin to the intergovernmen-

78 See text accompanying notes 38-47.

791 Stat 106 (April 2, 1790).

80 "[T]he object of the bill is to make it the duty of the collectors to attend to the execution of the State Inspection Laws . . . ." 2 Annals at 1527 (Rep Smith).

s1 Id at 1527.

82 See The Second Century at 175, discussing Brooks v United States, 267 US 432, 439 (1925).

83 1 Stat 73, 76-79 $\$ \$ 9,11$ (Sept 24, 1789).

\& See Huntington $v$ Attrill, 146 US 657, 669 (1892). 
tal immunity later recognized in M'Culloch $v$ Maryland; the majority seemed to think there was no such limitation. ${ }^{85}$

The more serious objection, perhaps, lay elsewhere. The effect of requiring compliance with state inspection laws was to make changing state laws the measure of federal rights and thus arguably to delegate to state legislatures the power that the Constitution had conferred on Congress. Later statutes forbidding the transportation of liquor in violation of state law and adopting state criminal laws to govern federal reservations would pose similar problems. ${ }^{86}$ The enactment of the inspection law suggests that the First Congress saw no constitutional obstacle to such cooperative uses of federal power.

\section{E. Seamen}

Possibly the most ambitious exercise of the commerce power during the First Congress was the enactment in July 1790 of a comprehensive labor law for merchant seamen. ${ }^{87}$ On the one hand this Act provided stringent sanctions against sailors who deserted or failed to report and those who harbored them. ${ }^{88}$ On the other hand it guaranteed crew members a written contract, prompt payment of wages, adequate medicines and provender, and the right to require a leaky vessel to put into port for repairs. $^{89}$

Unfortunately the Annals report no debate on these provisions. Their most plausible source of support was the Commerce Clause, and that was the basis on which they were subsequently explained. ${ }^{90}$ It was not obvious, however, that a regulation of the care and feeding of seamen was a regulation of commerce. Transportation was commerce, as the ship licensing law implied, and crew members were engaged in transportation. Yet the law

ss 17 US at 429-30.

${ }_{83}$ See Clark Distilling Co. v Western Maryland Railway, 242 US 311, 326-32 (1917); United States $v$ Sharpnack, 355 US 286 (1958); The Second Century at 115 n 150.

871 Stat 131 (July 20, 1790).

88 Id at 131-34 $\$ 82,4,5,7$.

Id at 131-35 $\S 1,3,6,8,9$.

${ }^{\infty}$ See text accompanying note 202 . The reader may recall that much later the Supreme Court would find the enactment of statutes respecting the shipping business necessary and proper to the exercise of the admiralty jurisdiction conferred on federal courts pursuant to Article III. See In re Garnett, 141 US 1, 12 (1891); The Second Century at $27 \mathrm{n} \mathrm{139}$. If the notion that laws facilitate the decision of cases seems reasonable enough, it also implies a fairly broad understanding of the words "necessary and proper." In any event there is no evidence in the Annals that Congress in enacting the seamen's law thought it was acting under the Admiralty Clause. 
regulated not transportation itself but the labor relations of those who did the transporting. ${ }^{91}$

On the other hand, both the duties and the rights created by this law obviously promoted commerce by assuring that ships would be properly manned. If the bill did not regulate commerce itself, it could easily be found necessary and proper to the commerce power. In the early twentieth century, when Congress for similar reasons attempted to give railroad workers the right to join unions and to receive pensions, the Supreme Court held it had exceeded its powers. ${ }^{92}$ The First Congress plainly took a broader view of its Commerce Clause authority. ${ }^{93}$

\section{F. The Slave Trade}

The clouds of future storms darkened the halls of Congress in February 1790 when Representative Fitzsimons presented an address from an assembly of Quakers urging Congress to do something about the slave trade. ${ }^{94}$ South Carolina's William Smith protested that the House should not even consider the petition because Article $I, \S 9$ deprived Congress of the power to ban importation of slaves into existing states before $1808 .^{95}$ Madison had already pointed out, however, that the same provision expressly permitted a federal tax not exceeding ten dollars a head $^{96}$ and suggested that Congress might also have authority

91 Moreover, like the licensing law, the statute was not expressly limited to seamen engaged on vessels employed in commerce "with foreign nations, and among the several States, and with the Indian tribes." US Const, Art I, § 8, cl 3.

${ }_{92}$ See Adair v United States, 208 US 161 (1908); Railroad Retirement Board $v$ Alton Railroad, 295 US 330 (1935); The Second Century at 27, 232-33.

${ }^{23}$ Three provisions of this statute raised federalism questions of a very different sort by providing for the participation of state officials in the enforcement of federal law. Section 2 made penalties payable to the owner by delinquent seamen "recoverable in any court, or before any justice or justices of any state, city, town or county within the United States" having "cognizance of debts of equal value," while making no provision for federal jurisdiction. 1 Stat at 132. Section 3 "required" local justices of the peace, in places where no federal district judge resided, to resolve controversies between master and crew over the seaworthiness of a vessel. Id. Section 7 authorized "any justice of the peace within the United States" to issue warrants for the arrest of delinquent sailors and directed the justices upon a finding of delinquency to commit them "to the house of correction or common gaol of the city, town or place" pending departure of the vessel. Id at 134. A year earlier Congress had passed a resolution that "recommended" passage of state legislation permitting federal convicts to be housed in state jails, 1 Stat 96, 96-97 (Sept 23, 1789), but the seamen's act seemed to be phrased as an order rather than a request. Consider Testa v Katt, 330 US 386, 394 (1947); New York v United States, 112 S Ct 2408, 2427-31 (1992) (holding Congress cannot compel states to regulate radioactive waste disposal).

24 1 Annals at 1224-25.

95 Id at 1230.

96 An earlier proposal to add such a tax to the tariff bill, ably supported by Madison, 
to outlaw the transportation of slaves from Africa to the West Indies in American ships ${ }^{97}$ - thus implying both that the transportation of slaves was commerce and that trade with foreign nations included trade by Americans between them.

Jackson of Georgia protested that anything done to suppress the slave trade might threaten slavery itself, ${ }^{98}$ and the very next day, a memorial signed by no less a personage than Benjamin Franklin urged Congress to take steps under unspecified powers to free the slaves. ${ }^{99}$ Representatives from the deep South began to squeal like stuck pigs. Smith warned that emancipation would offend the constitutional ban on ex post facto legislation, ${ }^{100}$ Tucker that it would bring about civil war. ${ }^{101}$ Baldwin declared that the requirement that direct taxes be apportioned according to the census was meant to prevent any special tax upon negro slaves. ${ }^{102}$ Madison responded that Congress had authority, presumably under Article IV, to regulate slavery in the western territory ${ }^{103}$ and the introduction of slaves into new states that might be formed there. ${ }^{104}$ Gerry suggested that Congress might raise money to purchase and free slaves by selling lands in the western territories. ${ }^{105}$ The protesters were noisy but badly outnumbered; both petitions were referred to a committee for consideration. ${ }^{106}$

had been withdrawn once it became evident that the controversy it engendered would delay passage of the bill itself. See id at 349-56. As Representative Parker said in introducing the amendment, its principal purpose was to "prevent, in some degree, this irrational and inhuman traffic," id at 349; no one suggested that this purpose made the proposal unconstitutional.

97 Id at 1226-27.

\$8 Id at 1228.

9 Id at 1239-40. In the brief debate on Parker's earlier proposal to tax the importation of slaves, Madison had made an argument that might have been extended to support the improbable conclusion that the war powers enabled Congress to abolish slavery: Any addition to the number of slaves diminished the capacity for self-defense, and anything that increased the dangers of war was "a proper subject for the consideration of those charged with the general administration of the Government." Id at 354.

100 Id at 1244.

101 Id at 1240.

102 Id at 1243, citing US Const, Art I, $\$ 9$, cls $1,4$.

103 "He adverted to the western country-and the cession of Georgia in which Congress have certainly the power to regulate the subject of slavery ...." Gazette of the United States (Feb 17, 1790).

104 Annals at 1246.

105 Id at 1247.

106 Id. Representative Smith of South Carolina suggested privately that his defeat on this motion might have been a Pyrrhic one: "I think we so effectually tired the members out \& embarrassed them that they will not be in a hurry to bring the subject on again." Letter of William L. Smith to Edward Rutledge, Feb 13, 1790, in George C. Rogers, Jr., 
Predictably, the committee reported that Congress had no power to interfere with slavery itself, or to forbid importation of additional slaves into the original states before 1808. It added, however, that Congress did have authority to impose a ten-dollar tax on each slave imported, to forbid citizens to transport slaves between foreign countries, and to provide for the humane treatment of slaves during importation. The report concluded by urging that Congress exercise all these powers "for the humane objects of the memorialists, so far as they can be promoted on the principles of justice, humanity, and good policy."107

This committee report provoked five more days of heated debate. Aedanus Burke of South Carolina insisted that slavery was good for slaves and vilified the Quakers. ${ }^{108}$ Smith enlarged upon Burke's remarks, trumpeted states' rights, and disparaged blacks in general. ${ }^{109}$ Boudinot expatiated at length on the evils of slavery, acknowledged that there were serious limits to what Congress could do about it, and stood up for the petitioners. ${ }^{110}$ The upshot was a report of the Committee of the Whole House largely restating the original committee's conclusions concerning the extent of congressional powers but omitting any reference to the desirability of their exercise. ${ }^{111}$

With that the House dropped the subject for the time being, but the spirit of dissension it had awakened had come to stay.

ed, Letters of William Loughton Smith to Edward Rutledge, 69 Carolina Historical Magazine 101, 104 (1968).

1072 Annals at $1465-66$.

108 Id at 1502.

109 Id at 1503-14. "The Gentlemen from S[outh] Carolina [and] Georgia," wrote Madison, "are intemperate beyond all example and even all decorum." Letter of James Madison to Benjamin Rush, March 20, 1790, in 13 Madison Papers at 109 (cited in note 1).

1102 Annals at 1517-22. Though the Annals are particularly unhelpful on this score, other sources reveal a variety of attacks on particular conclusions in the committee report. Tucker argued that foreign commerce "can only mean betwixt this country and foreign countries," lest Congress have power to provide "that no person shall, when in a foreign country, buy himself a shirt or a coat." Smith protested that if Congress could regulate the conditions of transport it might effectively ban importation by prescribing that no more than one slave per each two tons of burthen be carried in each ship. Baldwin agreed with both of them, while Scott, at the opposite end of the spectrum, insisted that Congress could ban importation immediately because slaves were not "persons" within the meaning of the limitation in Art I, § 9. See New York Daily Gazette (Mar 23 and 26, 1790).

1112 Annals at 1523-25. 


\section{SPENDING}

\section{A. Appropriations}

Federal spending involves challenging questions of separation of powers. For by virtue of the Appropriations Clause of Article I, $\S 9$, the power of the purse extends to the disbursement as well as the raising of funds; both are subject to congressional control. ${ }^{112}$

The First Congress was not always meticulous in defining how the money it appropriated should be spent. The basic appropriation statute for 1789 , for example, provided $\$ 137,000$ for the War Department, $\$ 190,000$ to discharge old treasury warrants, $\$ 96,000$ for veterans' pensions, and $\$ 216,000$ for defraying the expenses of the civil list, which included virtually everything else. ${ }^{113}$ The corresponding law for the following year-although passed more or less in advance-granted precise sums for the payment of named debtors and for the construction of a particular lighthouse, but contained a military appropriation as general as that of the previous statute. Moreover, it allotted the President a $\$ 10,000$ fund for contingent charges of the government without attaching any strings whatever. ${ }^{114}$

Maclay objected vehemently to Congress's failure to specify the objects of federal spending:

The Appropriations were all in Gross, to the amount of Upwards of half a Million .... [T] [Te particulars are not mentioned[. T] he Estimate on which it was founded may be mislaid or changed[. I]n fact it is giving the Secretary the Money for him to account for as he pleases. This is certainly all Wrong[. T] he estimate should have formed part of the bill or should have been recited in it. ${ }^{115}$

In what may have been a response to such criticism, the 1791 statute appropriated lump sums for the expenses of the civil list

112 For the history of legislative control of expenditures in England and the states before adoption of the Constitution, see Gerhard Casper, Appropriations of Power, 13 U Ark Little Rock L J 1, 3-8 (1990).

1131 Stat 95 (Sept 29, 1789). Hamilton's detailed estimates, made in response to instructions from the House pursuant to the statute by which the Treasury Department was created, were the source of these figures. The sums appropriated for the civil list and for the War Department, however, were somewhat less than Hamilton had requested. See 5 Hamilton Papers at 379-92 (cited in note 48) (civil list short \$27,000; War Department short $\$ 26,000) ; 2$ Annals at 2231-33; 1 Stat 65, 65-66, § 2.

114 Stat 104, 104-06 (March 26, 1790).

11 William Maclay, Diary (March 22, 1790), in 9 Doc Hist at 225-26. 
"as estimated by the Secretary of the Treasury, in the statement ... accompanying his report to the House of Representatives"116 - a formulation that represented a sea change in congressional control of expenditures if, as seems probable, it was intended to bind the Secretary to the allocation of funds that he had proposed. ${ }^{117}$ It is certainly arguable that the revised formula more nearly captured the spirit of the constitutional provision.

\section{B. Lighthouses}

As already noted, one of the 1790 appropriation law's more specific provisions granted a named sum for discharging obligations specified in a particular report, "including [ ] a provision for building a light-house on Cape Henry in the State of Virginia." 118 Construction of the lighthouse had been authorized by a statute enacted in August of the preceding year. ${ }^{119}$ The same legislation authorized federal spending for the maintenance and repair of all "lighthouses, beacons, buoys and public piers" previously erected for navigational purposes "within any bay, inlet, harbor, or port of the United States" pending their prompt cession to the United States. ${ }^{120}$

Thus the aim of this enactment was to put the federal government in the business of constructing, operating, and financing a nationwide system of aids to navigation. The interesting ques-

1161 Stat 190 (Feb 11, 1791).

117 See Casper, $13 \mathrm{U}$ Ark Little Rock $\mathrm{L} J$ at $10-12$ (cited in note 112); Lucius Wilmerding, Jr., The Spending Power: A History of the Efforts of Congress to Control Expenditures 22 (Yale, 1943). In fact the final version of the 1790 bill Maclay was protesting contained a similar clause, although no comparable language seemed to qualify the War Department's appropriation until the next year. At the time Maclay wrote he was unaware of what the bill actually said. As he wrote in his diary: "I could not get a copy of it. I wished to have Seen the particulars specifyed but such an hurry I never saw before." Maclay, Diary, March 22, 1790, in 9 Doc Hist at 226.

1181 Stat at 105.

1191 Stat 53, 54 \& 2 (Aug 7, 1789): "[A] lighthouse shall be erected near the entrance of the Chesapeake Bay, at such place ... as the President ... shall direct." The leeway permitted in selecting the site seems sufficiently narrow to obviate any serious objection that this provision delegated legislative power to the President. The absence of any specifications for the construction itself and the further provision directing the Secretary of the Treasury to fix the salaries of unspecified "persons appointed by the President" to look after the facilities showed that Congress believed it could give executive officers significant discretion in the management of government property, but even in these matters the Secretary and the President could fairly be said to be executing a policy decision made by Congress itself. Compare United States $v$ Grimaud, 220 US 506, 521-22 (1911); The Second Century at $115 \mathrm{n} 150$.

1201 Stat at $53-54, \S 1$. 
tion is where it got the authority to do so; ${ }^{121}$ for spending, like taxation, poses questions not only of separation of powers but of federalism as well.

Observers in the late twentieth century are likely to think at once of the first clause of Article I, § 8, which empowers Congress "to lay and collect taxes, duties, imposts and excises, to pay the debts and provide for the common defense and general welfare of the United States." The modern Supreme Court, while acknowledging that the enumeration of congressional powers precludes interpreting this provision to support all legislation that promotes the general welfare, has nevertheless read it to justify taxation to acquire and expend funds for any such purpose $\mathrm{e}^{122}$ and thus to confer a power that, as experience has taught, seriously undermines the Constitution's carefully crafted limitations on federal authority. ${ }^{123}$

It would be remarkable if the First Congress had entertained any such view of its powers, and in fact there were narrower and less sweeping arguments for the statute in question. The power of "exclusive legislation" over "places purchased" with state consent "for the erection of forts, magazines, arsenals, dock-yards and other needful buildings"124 will not do the trick; even if buoys are buildings and the provision is not limited to strictly military facilities analogous to those specifically listed, this authority cannot easily be made to embrace expenditures to maintain installations not yet owned by the United States. ${ }^{125}$ On the other hand, lighthouses and other navigational aids are as useful to naval vessels as they are to any others; even in 1789 one might conceivably have argued that they were necessary and proper to provide and maintain a (future) navy. ${ }^{126}$

The most obvious argument for federal navigational aids, however, was based on the Commerce Clause. Navigation is com-

${ }^{121}$ At the time of the Convention, Maryland Delegate James McHenry had lamented in his notes that the Constitution did not appear to empower Congress to "erect light houses or clean out or preserve the navigation of harbours," although the expense was one that "ought to be borne . . . by the general treasury . . . " Farrand, 2 Convention Records at 504 (cited in note 35) (emphasis omitted).

122 United States $v$ Butler, 297 US 1, 64-65 (1936).

${ }_{123}$ See The Second Century at 228-31; South Dakota v Dole, 483 US 203, 207, 212 (1987) (upholding a statute withholding federal highway funds from states that permitted the sale of alcoholic beverages to persons under 21 years of age).

121 US Const, Art I, \& 8, cl 17.

${ }^{125}$ A modern lawyer would find a way: Repairs help to maintain the value of navigational aids and thus are necessary and proper to federal operation after the property is acquired. Compare Wickard v Filburn, 317 US 111, 128-29 (1942).

128 US Const, Art I, \& 8, cl 13. 
merce, as Congress concluded in enacting the ship licensing law; buoys, beacons, and lighthouses promote interstate and foreign trade and thus are necessary and proper to carry out the purposes for which the commerce power was granted. This seemed to be Madison's theory in advocating that tonnage duties be imposed in order to support lighthouses, marine hospitals, "and other establishments incident to commerce"; ${ }^{127}$ and Fitzsimons expressly embraced it in opposing Tucker's suggestion that the entire subject be left to the states. ${ }^{128}$

The immediate objection to this line of reasoning is that the construction and operation of these establishments is not itself regulation of commerce, and not obviously necessary or proper for its regulation, which is what the Constitution seems literally to require. In light of the patent relation between navigation aids and the purposes of the commerce provision, however, it may be appropriate not to parse the Necessary and Proper Clause with the ferocity of a medieval conveyancer. As somebody would soon admonish us, it was a constitution we were expounding. ${ }^{129}$

1221 Annals at 183. In March of 1790 the House defeated a motion by Representative Jackson of Georgia to appropriate funds for removing obstructions to navigation in the Savannah River. 2 Annals at 1499-1500. The proposed expenditure was necessary and proper to facilitate commerce in the same way a lighthouse was, and none of the recorded objections was on constitutional grounds. See Gazette of the United States (March 17, 1790) (Reps Fitzsimons and Bland); Lloyd's Notes (March 15, 1790) (Rep Boudinot). Congress evidently thought it better policy to let the state place the burden on those who benefitted directly, for it consented to the imposition of a state tonnage tax. 1 Stat at 18485; Maclay, Diary (Dec 28, 1790), in 9 Doc Hist at 349. See also note 18.

${ }^{123}$ See Daily Advertiser (July 17, 1789), in 11 Doc Hist at 1130. Tucker replied, without elaboration, that "these establishments were not necessarily incidental to the power of commerce." Id. Fitzsimons, not content to assert that federal action was both lawful and preferable, argued that the subject could not be left to the states, since "regulations respecting light houses and pilots were a part of the commercial system and had been given up by the states." Id. This view foreshadowed two centuries of litigation over the extent to which the grant of commerce power to Congress implicitly limited state authority.

129 See M'Culloch $v$ Maryland, 17 US at 407, 413-15. The last section of the same statute provided that "pilots in the bays, inlets, rivers, harbors and ports of the United States" should "continue to be regulated in conformity with the existing laws of the States ... or with such laws as the States may respectively hereafter enact... until further legislative provision shall be made by Congress." 1 Stat at $54 \S 4$. Regulation of pilots was obviously relevant to the conduct of commerce, but by leaving the matter to future state regulation Congress opened itself to the argument that it could neither delegate the power to make federal law to the states (consider the discussion of federal enforcement of state inspection laws in the text accompanying note 82) nor remove limitations on state authority that might be implicit in the Commerce Clause itself. See Cooley $v$ Board of Wardens of the Port of Philadelphia, 53 US 299, 313-21 (1852) (accepting the latter argument but holding that state law could constitutionally be applied even without congressional consent). Contrast the express provisions of Art I, \& 10 prohibiting state tariffs and tonnage duties in the absence of congressional approval, as discussed in note 


\section{Other Spending Proposals}

The First Congress considered three additional spending suggestions that could not be justified so easily. Their fate illustrates the diversity of views as to the extent of congressional authority to spend.

The first was the argument of two Virginia representatives that Congress should underwrite a private voyage to Baffin's Bay in search of a better understanding of the magnetic pole. ${ }^{130} \mathrm{Nei}-$ ther member explicitly identified the source of Congress's alleged authority. Page seemed to believe in a broad power to spend for the general welfare, for he said only that the knowledge to be obtained "would do honor to the American name." Madison, in suggesting that the voyage might contribute to "improving the science of navigation," ubiquitous Commerce Clause-though the relation to commerce seemed more attenuated here than in the case of an honest-togoodness lighthouse. ${ }^{133}$ Ignoring the commerce power, Tucker expressed doubt whether the Patent Clause authorized Congress "to go further in rewarding the inventors of useful machines, or discoveries in sciences, than merely to secure to them for a time the right of making, publishing and vending them"134-a doubt solidly supported by the text of the provision. In the face of these uncertainties, and in view of "the present deranged state of our finances," the House agreed with the committee recommendation not to subsidize the voyage; ${ }^{135}$ the constitutional question did not have to be decided.

The second spending suggestion was Washington's startling invitation to Congress in his first State of the Union message to "promo[te] science and literature" either "by affording aids to seminaries of learning already established" or "by the institution of a national university." ${ }^{\text {"136 }}$ Like Page and Madison, the Presi-

18. For a discussion of this issue, see The First Hundred Years at 330-35.

1301 Annals at 178-80 (Reps Madison and Page).

231 Id at 180.

132 Id at 179 .

${ }^{133}$ See Brant, James Madison at 332 (cited in note 13): " [A] ship captain did not need to know the cause of compass deviations in order to use the charts recording them. The fact was that [Madison] wanted to send out a purely scientific expedition, which could be justified only by a sweeping interpretation of the power to spend for the general welfare." A war powers argument would have been no less plausible but subject to the same objection.

1 Annals at 180.

13 Id at $178,180$.

136 Id at 970 . 
dent did not discuss the issue of congressional authority. His reference to the promotion of science suggests the same reliance on the Patent Clause that Tucker had so tellingly refuted a few months before, and any argument that support for education might produce information that would facilitate commerce seems even more attenuated here than in the chilly context of Baffin's Bay. Washington's additional observation that knowledge was conducive to stability and good government ${ }^{137}$ might seem to imply that support for education was necessary and proper to the intelligent exercise of all federal powers, but he seemed to be discussing policy rather than authority. More probably, if he thought about the problem of power at all, he either assumed the university would be constructed in the national capital ${ }^{138}$ or read the General Welfare Clause broadly. ${ }^{139}$ In any event, Congress put the proposal on the back burner; ${ }^{140}$ its constitutionality would be seriously debated a few years later. ${ }^{141}$

The final example of proposed federal spending was a committee recommendation in June 1790 that Congress authorize a loan of federal funds to rescue a glass factory that found itself in straitened circumstances. ${ }^{142}$ In tones reminiscent of the famous Report on Manufactures that Hamilton was to file a year and a half later, ${ }^{148}$ Vining argued that Congress possessed a general power to encourage the arts and manufactures of the United

137 Id.

${ }^{138}$ See US Const, Art I, § 8, cl 17: "The Congress shall have power ... To exercise exclusive legislation in all cases whatsoever, over such district ... as may . . . become the seat of the government of the United States ...."

139 See Brant, James Madison at 289 (cited in note 13): "All of the power found afterward in the 'general welfare' clause was latent in this recommendation."

${ }_{140}$ In May 1790, Smith moved to refer the President's suggestion to a select committee for study. Stone objected that Congress had done all it could to encourage learning by providing for copyrights; Sherman added that the Convention had rejected a proposal to give Congress authority to establish a national university. 2 Annals at 1603-04. It had done so, in fact, after Gouverneur Morris had dismissed the suggestion as unnecessary, since "[t]he exclusive power at the Seat of Government, will reach the object." Farrand, 2 Convention Records at 616 (cited in note 35). Page "rather supposed" Congress had that authority and favored commitment in order to resolve the question, but "the House adjourned without a decision." 2 Annals at 1604.

1416 Annals at 1697-1711.

142 Annals at 1685-86.

1431 American State Papers (Finance) at 123 (cited in note 20); 10 Hamilton Papers at 230 (Dec 5, 1791) (cited in note 48). This report grew out of the additional suggestion in Washington's 1790 Annual Message that "[a] free people" should "promote such manufactures as tend to render them independent of others for essential, particularly military supplies." 1 Annals at 969. The House had referred this suggestion to Hamilton. House Journal, Jan 15, 1790, reprinted in 3 Doc Hist at 265. 
States. ${ }^{144}$ His terminology suggested he too had not looked closely enough at the actual terms of the Patent Clause.

Smith and Sherman doubted that Congress could loan the money of their constituents, ${ }^{145}$ but as Boudinot said, their objection seemed too broad. ${ }^{146}$ Loans, no less than outright grants, might well be necessary and proper to the execution of some express federal authority; the difficulty lay in finding any power to which the support of a glass factory could fairly be deemed incidental. Of course glass was useful for commercial and military purposes, as well as to provide windows in all sorts of government buildings; but such an argument would leave little room for the powers that both the enumeration and the Tenth Amendment clearly acknowledged to be reserved only to the states. Ames's policy argument respecting the national interest in encouraging manufactures seemed to reflect a more straightforward reliance on the General Welfare Clause, which Boudinot, Seney, and Stone expressly invoked. ${ }^{147}$

The committee's recommendation was rejected, but not all of the objections were on constitutional grounds. The question of the extent of federal spending powers had thus been raised and debated, but it had not yet been resolved. ${ }^{148}$

14 2 Annals at 1686.

145 Id.

${ }_{146}$ Id. See also Lloyd's Notes (June 3, 1790) (Reps Seney and Vining).

167 See 2 Annals at 1687; Lloyd's Notes (June 3, 1790). Hamilton would be unequivocal in his recommendations to the Second Congress with respect to manufactures:

[With only the uniformity and apportionment requirements and the ban on export duties] excepted, the power to raise money is plenary, and indefinite; and the objects to which it may be appropriated are no less comprehensive, than the payment of the public debts and the providing for the common defence and "general Welfare." The terms "general Welfare" were doubtless intended to signify more than was expressed or imported in those which Preceded; otherwise numerous exigencies incident to the affairs of a Nation would have been left without a provision.

10 Hamilton Papers at 303 (cited in note 48).

143 The House's decision to furnish its members with newspapers at public expense, which could easily have been justified as necessary and proper to the informed exercise of the legislative function, was instead defended on the broader ground that the press deserved encouragement. See 1 Annals at 427; 2 Annals at 1580-82, 1835-36. Efforts to restrict the number of journals taken in the interest of economy were attacked as creating a risk of partiality-a preview of the problems that later were to complicate government support of arts and letters. See 2 Annals at 1581 (Rep Gerry), 1835 (Rep Madison). 


\section{The PuBlic CRedit}

The Revolution had been fought in substantial part on credit, and many creditors had not been paid. ${ }^{149}$ When a group of public creditors from Pennsylvania petitioned for relief, the House adopted a resolution declaring that an adequate provision for the support of public credit was "a matter of high importance to the national honor and prosperity" and directed the Secretary of the Treasury to propose an appropriate plan..$^{150}$

The Secretary was Alexander Hamilton. His response was a lengthy Report on Public Credit, ${ }^{151}$ the first in a remarkable series of reports in which the Secretary set forth his comprehensive and ambitious economic program. The United States, wrote Hamilton, would need to borrow money in the future (as Article I, § 8 authorized Congress to do). They could borrow only if their credit was good; and their credit would be good only if they paid their debts. Thus satisfaction of existing claims was required not only by justice but by self-interest as well. ${ }^{152}$ Money loaned by foreigners, he argued, should be paid back in full. The domestic debt, in contrast, should be refinanced rather than retired. Finally, Congress should also provide for paying off existing debts of individual states, since it was in a better position to raise money-and since after all many state obligations had been incurred in the interest of common defense. ${ }^{153}$

Congress wrestled with Hamilton's proposals for nearly six months and ultimately adopted the essence of his suggestions. ${ }^{154}$ In the process Washington's closest confidant became

149 See 6 Hamilton Papers at 69 (cited in note 48).

1501 Annals at 939 . The story of this whole controversy is ably and concisely told in McDonald, Washington at 47-75 (cited in note 13), and in Miller, The Federalist Era at 3354 (cited in note 7). See also E. James Ferguson, The Power of the Purse 289-325 (North Carolina, 1961).

${ }^{151} 6$ Hamilton Papers at 65 (cited in note 48); 1 American State Papers (Finance) at 15 (cited in note 20); 2 Annals at 2041 (Appendix).

${ }^{152}$ See also 1 Annals at 1171-77 (Rep Boudinot) (repeating Hamilton's arguments and concluding that Congress was bound by "honor, justice, and policy" to fund the existing debt); id at 1193-95 (Rep Ames).

153 See Miller, The Federalist Era at 37-40 (cited in note 7); McDonald, Hamilton at 167-68 (cited in note 13).

${ }^{154} 1$ Stat 138 (Aug 4, 1790). The Annals barely hint at the debate occasioned by a proposal to empower the Secretary of the Treasury to borrow money to discharge foreign debts. See 2 Annals at 1639. According to Lloyd's notes, when Madison objected that Congress should not sidestep the President by giving authority to his agent (see US Const, Art II, \& 1!), Smith doubted whether Congress could delegate its power to the President at all. Huntington understandably replied that members of Congress were not expected "to turn borrowers themselves," while Laurance suggested that nothing needed to be said 
the leader of the opposition and the future capital was fixed on the banks of the Potomac. For present purposes, however, the most important aspect of the controversy is the constitutional questions that it raised.

\section{A. Paper Money}

Hamilton's argument against retiring the domestic debt was in part that public securities would promote trade by serving as currency and thus increasing the money supply. ${ }^{155}$ The Constitution did not expressly say whether Congress had power to issue paper money. It did authorize Congress to coin money, ${ }^{156}$ but securities are not coins. It did forbid states to issue bills of credit or to make anything but gold and silver legal tender, ${ }^{157}$ but neither restriction seemed to prohibit circulating promissory notes, ${ }^{158}$ and neither applied to Congress.

Negotiable notes clearly facilitate borrowing and thus appear necessary and proper to the exercise of congressional power to borrow money. The Confederation Congress had issued such notes with common consent; nobody is recorded as doubting that the new Congress could do so too. ${ }^{159}$

\section{B. The Question of Full Payment}

Paying debts is plainly necessary and proper to incurring them; people rarely lend money without reasonable assurance of getting it back. Article I leaves no doubt of this, for it explicitly empowers Congress to tax in order "to pay the debts of the United States." ${ }^{\text {"160 }}$ Article VI removes any obstacle to the payment of debts contracted before the Constitution took effect: "All debts

about who was to do the borrowing: Once Congress had passed a borrowing law, it was the President's duty to enforce it. Madison's view prevailed; the statute vested borrowing authority in the President. See Lloyd's Notes (May 19, 1790); 1 Stat 138, 139 § 2.

${ }^{155} 6$ Hamilton Papers at 70-71 (cited in note 48); McDonald, Hamilton at 160 (cited in note 13).

${ }^{156}$ US Const, Art I, $\S 8$, cl 5.

157 US Const, Art I, \& 10, cl 1 .

158 See Briscoe $v$ Bank of Kentucky, 36 US 256, 299-300 (1837); The First Hundred Years at 206-08.

${ }^{159}$ See Kenneth W. Dam, The Legal Tender Cases, 1981 S Ct Rev 367, 382-90; James Willard Hurst, A Legal History of Money in the United States, 1774-1970 5-18 (Nebraska, 1973).

${ }_{100}$ For the answer to the alternative argument that this phrase confers a power independent of taxation, see the text accompanying note 122 (discussing the parallel General Welfare Clause). In the case of debts it hardly matters; Congress can pay them on either interpretation. 
contracted and engagements entered into, before the adoption of this Constitution, shall be as valid against the United States under this Constitution, as under the confederation."

Thus the important constitutional question raised by Hamilton's proposal to refinance the domestic federal debt was not whether Congress was permitted to provide for payment of pre-constitutional debts but whether it was required to do so. For several members of the House argued vigorously that at least some domestic creditors should not be given the full benefit of their bargain.

Livermore, for example, argued that many of these creditors were price-gouging suppliers who had taken advantage of common necessity to extort exorbitant profits and that (unlike foreign creditors) they had already been repaid in part by the benefits of independence. ${ }^{161}$ Scott and others contended that Congress ought to distinguish between original holders such as soldiers who had given full value for their securities and later speculators who had bought them up on the cheap. ${ }^{162}$

Hamilton had already pointed out that any such depreciation would deprive the assignee of the benefit of his bargain, impair the value of future securities to the original holder, and increase the cost of borrowing to the government. ${ }^{163}$ Several members of the House echoed his arguments ${ }^{164}$ and raised constitutional objections as well.

Laurance, Smith, Ames, and Boudinot variously suggested that reducing the claims of assignees would impair the obligation of contract, offend the Ex Post Facto Clause, and take property without compensation. ${ }^{165}$ Anticipating the obvious riposte that the Contract Clause applied only to the states, ${ }^{166}$ they could only argue lamely that anything the states could not do must be forbidden to Congress as well. ${ }^{167}$ Their remaining arguments were more plausible, since there was no doubt that the ex post facto

1611 Annals at 1185-87.

162 Id at 1205-06. See also id at 1224 (Rep Burke). Madison offered a variant of this proposal that would have provided for payment in full to be divided between the original holder and the assignee in proportion to their respective investments. See id at 1233-38.

${ }_{163} 6$ Hamilton Papers at 73-77 (cited in note 48).

164 See 1 Annals at 1212, 1238-39.

165 Id at 1251, 1257, 1263, 1294.

${ }_{166}$ See US Const, Art I, $\$ 10$.

${ }_{167}$ See 1 Annals at 1251, 1257, 1294. Compare Bolling $v$ Sharpe, 347 US 497 (1954) (reading the Equal Protection Clause into the Fifth Amendment by the same questionable reasoning). See also The Second Century at 378-79. 
and property provisions applied to the United States. ${ }^{168}$ Anticipating Calder $v$ Bull, Madison nevertheless replied with some force that the separate provision precluding state impairment of contracts showed that the Ex Post Facto Clauses reached only criminal laws. ${ }^{169}$ No one stopped to rebut the taking contention, but Madison's response was equally applicable here: Arguably the separate provisions respecting contracts and property implied that contractual rights did not come within the purview of the Taking Clause. ${ }^{170}$

Hamilton's more interesting argument, ${ }^{171}$ repeated by Boudinot in the House, ${ }^{172}$ was that discrimination against assignees of the original creditors was forbidden by Article VI, which made pre-constitutional debts "as valid against the United States under [the] Constitution, as under the Confederation." As Seney pointed out, however, the text of this article refuted any notion that it gave preexisting debts any more protection than they had enjoyed under the Confederation; ${ }^{173}$ and the Articles of Confederation had contained no provision forbidding Congress to renege on its obligations. ${ }^{174}$

Thus no convincing argument was made that Congress was constitutionally required to pay its debts in full. Moreover, despite the defeat of various motions to discriminate against assignees or suppliers of goods, the statute did not provide for full payment. While the new certificates issued in exchange for the old were to bear a full six percent, interest on one third of their value was to be paid only after the turn of the century; ${ }^{175}$ and

${ }_{168}$ US Const, Art I, $\$ 9, \mathrm{cl} 3$ and Amend V.

${ }_{169} 1$ Annals at 1311. See Calder, 3 US 386, 390 (1798); The First Hundred Years at $41-49$.

170 But compare Dartmouth College $v$ Woodward, 17 US 518 (1819) (holding what appeared to be a taking of property a violation of the Contract Clause); The First Hundred Years at 141-45.

1716 Hamilton Papers at 77 (cited in note 48).

1721 Annals at 1190. See also McDonald, Hamilton at 178 (cited in note 13).

1732 Annals at 1323. See also New York Daily Gazette (Feb 25, 1790).

174 Boudinot's final contention that to scale down payments to assignees would be to exercise judicial powers vested exclusively in the courts by Article III, 1 Annals at 1294, had little to recommend it, since what was proposed was general legislation applicable to all existing domestic obligations. Contrast Fletcher v Peck, 10 US 87, 136 (1810), described in The First Hundred Years at 130-32, where Chief Justice Marshall suggested that the statutory repudiation of a single contract was an exercise of judicial rather than legislative power.

1751 Stat at $140 \S 4$. Section 9 provided that the statute did not disparage the rights of creditors who chose not to make the exchange, but $\S 10$ provided that they should receive the same interest as if they had done so. Id at 141-42. Except for the bills of credit noted below, the domestic debt had all been consolidated into securities bearing an 
preconstitutional bills of credit (the discredited "continentals") were to be redeemed at the princely rate of 100 to $1 .{ }^{176}$ As Sedgwick said, nobody was really for full payment, ${ }^{177}$ and the Constitution did not seem to require it. Nearly 150 years would pass before the Supreme Court surprisingly concluded that it did. ${ }^{178}$

\section{Assumption of State Debts}

In both political and constitutional terms, the most fascinating controversy related to public credit concerned Hamilton's proposal that Congress assume the debts of the several states. Predictably, those states that had already discharged the bulk of their obligations were less than eager to help discharge the obligations of others. ${ }^{179}$ Moreover, several Representatives recognized-as Hamilton is said to have intended-that federal assumption would enhance the power of the federal government relative to that of the states by reducing the necessity for state taxation. ${ }^{180}$

At the constitutional level, Stone began by observing that Article I empowered Congress to pay only "the debts ... of the United States," not those of individual states. ${ }^{181}$ Once state debts were assumed, of course, they would become debts of the United States; but that did not prove that Congress had the power to assume them. Nor did Article VI help in this regard, for as noted above it made debts good against the new Congress only

interest rate of 6 percent before the Constitution was adopted. 6 Hamilton Papers at 84, 86 (cited in note 48 ).

1761 Stat at $140 \S 3$. The continentals had previously been officially devalued at a rate of 40 to 1. See 16 Journals at 262-67 (March 18, 1780). See also Miller, The Federalist Era at 37 (cited in note 7); McDonald, Hamilton at 147 (cited in note 13).

171 Annals at 1210-11. Hamilton himself had acknowledged that repudiation might be justified by "necessity." 6 Hamilton Papers at 68.

${ }_{178}$ See Perry v United States (the Gold Clause Cases), 294 US 330, 350-51, 357 (1935) (finding the duty to repay implicit in the power to borrow but taking it back by implausibly concluding that the complainants had suffered no harm). See The Second Century at 233-34.

179 See 2 Annals at 1404-05 (Rep White), 1427 (Rep Madison). See also Madison's letter to Jefferson, March 8, 1790, in 16 Jefferson Papers at 213 (cited in note 12), opposing assumption, which as devised would principally benefit South Carolina and Massachusetts and "would be peculiarly hard on Virginia." For a more sophisticated version of this argument, see Ferguson, The Power of the Purse at 307-11 (cited in note 150).

${ }_{180}$ See, for example, 2 Annals at 1359 (Rep Stone); Miller, The Federalist Era at 40-41 (cited in note 7); McDonald, Hamilton at 167 (cited in note 13).

1812 Annals at 1361. 
to the extent they had been good against the old; it too seemed to apply only to obligations of the United States.

Sedgwick found authority for the assumption of state debts in a broad reading of the General Welfare Clause of Article I, § 8, which he said authorized Congress "to levy money in all instances where, in their opinion, the expenditure shall be for the 'general welfare'... [I]f prudence, policy, and justice dictated the assumption of the State debts it must be for the general welfare that they should be assumed."182 Even before Sedgwick spoke, however, Stone had branded as dangerous any argument that Congress could tax and spend for a purpose that might be deemed salutary but that was "not a constitutional object of their power"; ${ }^{183}$ and most defenders of assumption espoused a narrower justification.

The debts in question, Sherman argued, had been incurred for the most part (as Hamilton had noted) "for the common defence." ${ }^{\text {184 }}$ That defense had been the responsibility of Congress, but Congress had been unable to raise the requisite funds. Consequently the states had contracted obligations as agents of Congress; from the beginning the state debts had been "debts ... of the United States." ${ }^{\prime 185}$ Two former members of the constitutional convention relied on their recollection of its proceedings in support of their conflicting interpretations. Madison insisted that the Convention had decided not to assume state debts, ${ }^{186}$ Gerry that it had taken for granted Congress would have power to do so. ${ }^{187}$

182 Id at 1382.

183 Id at 1361.

184 Id at 1365. See also 6 Hamilton Papers at 81-83 (cited in note 48).

185 See also 2 Annals at 1371-72, 1397 (Rep Gerry); id at 1407 (Rep Smith of South Carolina); id at 1647-69 (Reps Boudinot and Ames). The thesis that "debts" included quasi-contractual as well as contractual obligations received further support when Congress empowered federal commissioners appointed to settle accounts between the United States and individual states to recognize all claims "accrued for the general or particular defence during the war," whether or not "sanctioned by the resolves of Congress, or supported by regular vouchers," "according to the principles of general equity ...." 1 Stat 178,179 \& 3 (Aug 5, 1790).

1862 Annals at 1591.

${ }^{187}$ Id at 1409-10. In fact the Convention record is ambiguous on this score. The original proposal would have given Congress authority to discharge both federal and state debts. Farrand, 2 Convention Records at 355-56 (cited in note 35) (Madison's notes). The reference to state obligations was omitted when the provision was altered to make payment of federal debts mandatory. Id at 377 . The most that can be said with confidence is that the framers decided not to require Congress to discharge state obligations. 
The House initially voted against assumption. ${ }^{188}$ At that point Secretary of State Jefferson arranged an informal meeting between Hamilton and Madison, who as a representative of a state that had paid most of its own debts, had opposed assumption tooth and nail. The result was a compromise whereby in exchange for assumption of debts actually incurred for the common defense ${ }^{189}$ Virginia received both assurance of reimbursement for the sums it had already expended ${ }^{190}$ and the future seat of the national government; $;^{191}$ but the breach between Madison and the administration was never to be mended. ${ }^{192}$

\section{THE BANK OF THE UNITED STATES}

Resolution of the controversy over assumption of state debts brought the second session of the First Congress to a dramatic close. On the same day on which the House approved the bill providing for payment of existing debts, it asked the Secretary of the Treasury to propose "such further provision as may, in his opinion, be necessary for establishing the public credit." 193 Four months later, in December 1790, Hamilton responded with two more of his impressive economic reports. The first, which proposed additional taxes on whiskey, has already been discussed. ${ }^{194}$ The second, which is better known, framed the great constitutional issue that dominated the third session. For in this report Hamilton urged Congress to establish a national bank. ${ }^{195}$

188 See 2 Annals at 1597; McDonald, Hamilton at 181 (cited in note 13).

189 Section 13 provided that no certificates would be redeemed if it were shown that they had not been issued for such a purpose. 1 Stat at 143.

1901 Stat at 143-44 $\$ \S 17-18$. See also 1 Stat 178,179 (Aug 5, 1790) (establishing a board to settle accounts between the United States and individual states, with particular reference to claims "accrued for the general or particular defence during the war"). In light of these developments, Madison wrote to his father on July 31, "in a pecuniary light, the assumption is no longer of much consequence to Virginia." 13 Madison Papers at 285 (cited in note 1).

191 See text accompanying notes 425-42. For Jefferson's later account of the bargain, see 17 Jefferson Papers at 205-07 (cited in note 12). Some insight into Jefferson's motives is afforded by a letter he wrote to Thomas Randolph on June 20, 1790: "In] they [Congress] separate without funding there is an end of the government." 16 Jefferson Papers at 540.

${ }^{192}$ See Brant, James Madison at 305 (cited in note 13) ("Madison sacrificed his congressional leadership when he undertook the fight for Revolutionary War veterans and other small creditors against speculators in and out of Congress.”).

2 Annals at 1763 (Aug 9, 1790).

194 See text accompanying notes 48-68.

1957 Hamilton Papers at 305 (cited in note 48); 1 American State Papers (Finance) at 67 (cited in note 20); 2 Annals at 2082 (Appendix). 
The Constitution did not expressly authorize Congress to set up banks. Moreover, as Madison hastened to point out during the House debate, the Convention had rejected a proposal to authorize Congress to create corporations. ${ }^{196}$ Gerry, who had invoked his own recollection of the Convention debates during the assumption controversy, ${ }^{197}$ gave several of the reasons that have since been given for ignoring the debates ${ }^{198}$ and sensibly added that the proposal before the Convention would have given Congress a general power of incorporation ${ }^{199}$-not authority to establish an institution that might be implicit in some other power explicitly granted to Congress.

Hamilton's report had not addressed the constitutional question, but it had spelled out the benefits that a bank would confer..$^{200}$ In the House, Fisher Ames took the lead in showing how these benefits brought the creation of the bank within various categories of congressional authority.

Commerce, Ames argued, could hardly be carried on without banknotes; thus the bank was implicit in the power to regulate commerce. Debts could hardly be paid without easy transfer of funds across the country; thus the bank was implicit in the power to pay the debts. Wars could hardly be fought without a bank to facilitate the raising of money; thus the bank was implicit in the

1962 Annals at 1945. See also Farrand, 2 Convention Records at 615-16 (cited in note 35).

197 See text accompanying note 187.

198 Noting the impropriety of relying "on the memory of the [delegates] for a history of their debates" and that "the opinions of the individual members ... are not to be considered as the opinions of the Convention," Gerry added that the records of the state ratifying conventions were no better since they were "generally partial and mutilated." 2 Annals at 2004-05. See also Hamilton's later report to the President on the constitutionality of the Bank:

[W] hatever may have been the intention of the framers of a constitution, ... [it] is to be sought for in the instrument itself, according to the usual \& established rules of construction .... If then a power to erect a corporation ... be deducible by fair inference from the whole or any part of the ... constitution ..., arguments drawn from extrinsic circumstances, regarding the intention of the convention, must be rejected.

8 Hamilton Papers at 97, 111 (cited in note 48).

${ }_{198}$ "[T] Congress to erect commercial corporations ...." 2 Annals at 2004-05. More precisely, the proposal initially made was limited to the construction of canals; Madison's attempt to enlarge it so as to authorize the grant of charters whenever "the interest of the U.S. might require \& the legislative provisions of individual States may be incompetent" failed; and then the canal provision itself was voted down. See Farrand, 2 Convention Records at 615-16 (cited in note 35).

2007 Hamilton Papers at $305-42$ (cited in note 48 ). 
various war powers. Money could not effectively be borrowed without a bank; thus the bank was implicit in the power to borrow. ${ }^{201}$ Congress had exercised implied authority from the beginning in taxing ships, building lighthouses, and regulating seamen, all on the theory that they were incident to the commerce power, ${ }^{202}$ the Necessary and Proper Clause confirmed that each grant of authority gave power to do whatever was needed to accomplish its goal..$^{203}$

Sedgwick, Boudinot, and Gerry ably seconded these arguments. ${ }^{204}$ Madison, who as Sedgwick noted had argued vigorously for the President's implicit power to remove executive officers, ${ }^{205}$ was the principal spokesman against implicit authority to establish a bank. This bill, he insisted, was not supported by the tax power, for it imposed no tax; nor by the power to borrow, for it borrowed no money. The General Welfare Clause, he continued, was not an independent grant of power but a limitation on the purposes for which taxes could be collected; ${ }^{206}$ the Neces-

2012 Annals at 1956-59 (also invoking the tax power). Moreover, Ames contended, Congress could always set up a bank at the seat of Government or in the Territories, where it had plenary powers, or to manage the Government's own property under Art IV, § 3 . In suggesting that this property included the Government's own shares in the bank itself, however, Ames seemed to be lifting himself by his bootstraps. Jackson went so far as to deny that Congress could establish a bank at any place subject to its exclusive jurisdiction, adding more persuasively that "if they should, they could not force the circulation of their paper one inch beyond the limits of those places." Id at 1968. See also id at 1985 (Rep Stone) ("It would be equally reasonable to say, that France, because within the limits of her own dominions, ... exercised exclusive legislation, that hence she had a right to legislate for the world."); Cohens $v$ Virginia, 19 US 264, 440-47 (1821) (holding that a federal statute authorizing a lottery in the District of Columbia did not legalize ticket sales elsewhere because Congress would not be presumed to interfere with state penal laws).

2022 Annals at 1954.

203 Id at 1959.

${ }^{204}$ Id at 1960-64 (Rep Sedgwick), 1970-79 (Rep Boudinot), 1997-2006 (Rep Gerry). "[T]he Constitution," said Sedgwick, "had expressly declared the ends of Legislation; but in almost every instance had left the means to the honest and sober discretion of the Legislature." Id at 1962.

${ }_{205}$ Id at 1960. For Madison's defense of presidential removal, see 1 Annals at 516.

206 To construe it more broadly, Madison insisted, "would render nugatory the enumeration of particular powers." 2 Annals at 1946. Moreover, he added, the general purposes listed in the tax provision "themselves were limited and explained by the particular enumeration subjoined." Id. The terms of this provision were "copied from the articles of Confederation; had it ever been pretended, that they were to be understood otherwise than as here explained?" Id. See the Articles of Confederation, Art VIII: "All charges of war, and all other expenses that shall be incurred for the common defence or general welfare, ... shall be defrayed out of a common treasury, which shall be supplied by the several States ...." 
sary and Proper Clause was "merely declaratory of what would have resulted by unavoidable implication." 207

It was not enough, said Madison, that a measure might be "conducive" to the exercise of some express authority. Under such an interpretation, manufacturing subsidies or even a prohibition of state taxation might be held necessary and proper to the collection of federal taxes, since they would increase the ability to pay. ${ }^{208}$ "If implications, thus remote and thus multiplied, can be linked together, a chain may be formed that will reach every object ... within the whole compass of political economy",209 and "[t] he essential characteristic of the Government, as composed of limited and enumerated powers, would be destroyed ...."210 A national bank, he concluded, was not necessary: "Its uses to the Government could be supplied by keeping the taxes a little in advance; by loans from individuals; [and] by the other Banks, over which the Government would have equal command ....."211

Madison was as eloquent on one side of the bank question as Ames had been on the other. The House approved the Bank by the lopsided vote of 39 to $20,,^{212}$ and the Senate agreed without calling the roll. ${ }^{213}$ Disconcerted by Madison's arguments, Washington called upon Jefferson and Randolph for opinions, which

\footnotetext{
2072 Annals at 1947.

208 Id at 1948.

200 Id at 1949.

210 Id at 1947.
}

211 Id at 1950. For further remarks by Madison along the same lines, see id at 200812. See also id at 1967-70 (Rep Jackson), 1981-88 (Rep Stone), 1989-97 (Rep Giles) ("I have been taught to conceive that the true exposition of a necessary mean to produce a given end was that mean without which the end could not be produced."). For the argument that in opposing the bank Madison was inconsistent with the broad view of implied powers he had taken as early as $\mathbf{1 7 8 1}$ in a report to the Continental Congress, reiterated in the Federalist, and espoused in urging support for the expedition to Baffin's Bay, see Brant, James Madison at 331-33 (cited in note 13) (adding that Madison "deliberately abandoned his majority leadership when he saw that the price of keeping it was to become a tool of financial oligarchy"). For a more cynical view, see McDonald, Hamilton at 199-204 (cited in note 13) (arguing that Madison had nothing against the bank itself but saw its 20-year charter as a possible means of frustrating the move of the national capital to the Potomac, in which he had a financial interest, and explaining Washington's hesitation in signing the bill on similar grounds). Accord Kenneth R. Bowling, The Bank Bill, the Capital City and President Washington, 1 Capitol Studies 59 (1972).

212 Annals at 2012.

213 Id at 1813. 
echoed Madison's position. ${ }^{214}$ Hamilton then expanded on Ames's defense of the Bank ${ }^{215}$ and Washington signed the bill. ${ }^{216}$

As in the case of presidential removal power, the congressional and executive debate on the bank thoroughly rehearsed the arguments that would inform the later judicial decision. ${ }^{217}$ There was just one difference: Unlike Ames and Hamilton, Chief Justice Marshall never bothered to explain how the establishment of the bank was necessary, proper, or even conducive to the execution of any of the powers expressly granted to Congress. ${ }^{218}$

\section{MILITARY, INDIAN, AND FOREIGN AFFAIRS}

Having set up the Department of Foreign Affairs, renamed it the Department of State, and provided funds for diplomatic salaries, ${ }^{219}$ the First Congress passed no other major legislation in the field of foreign affairs. Having established ground rules for the process of advice and consent, the Senate was asked to approve only a single foreign treaty, which had been concluded before the new government began operations. ${ }^{220}$ However, Congress did begin the process of creating a new military establishment, confront a number of important constitutional issues in connection with the ticklish relations between the United States and the Indian tribes, and afford a preview of controversies to come as it began to wrestle with the question of what to do about the Barbary pirates.

214 See 19 Jefferson Papers at 275 (Feb 15, 1791) (cited in note 12); McDonald, Hamilton at 202 (cited in note 13). Apparently the Randolph opinion has never been published. See US Const, Art II, $\S 2$, cl 1: "The President ... may require the opinion, in writing, of the principal officer in each of the executive departments, upon any subject relating to the duties of their respective offices ...."

2158 Hamilton Papers at 97-134 (cited in note 48). Clinton Rossiter has termed Hamilton's response "perhaps the most brilliant and influential one-man effort in the long history of American constitutional law." Alexander Hamilton and the Constitution 79-80 (Harcourt, Brace \& World, 1964).

2161 Stat 191 (Feb 25, 1791). The preamble recited that the bank would be "conducive to the successful conducting of the national finances," facilitate borrowing, and promote commerce. Id. For Madison's draft of a veto message on both constitutional and policy grounds, see 13 Madison Papers at 395 (cited in note 1).

${ }^{217}$ See M'Culloch $v$ Maryland, 17 US 316 (1819).

${ }_{218}$ See The First Hundred Years at 164-65; M'Culloch, 17 US at 422 (stating the bank's utility was "not now a subject of controversy").

219 These topics, as well as the question of treaty-making procedure noted in the next sentence, are discussed in a separate paper dealing with issues of government structure in the First Congress. See note 14.

220 The treaty was a consular convention with France, signed and ratified in 1788. See 8 Stat 106 (Nov 14, 1788). 
A. Soldiers

On August 10, 1789, President Washington sent a message to the House regarding military troops then in the service of the United States. There were 672 of them, according to the accompanying report; they had been raised pursuant to resolutions of the Confederation Congress "in order to protect the frontiers from the depredations of the hostile Indians, to prevent all intrusions on the public lands, and to facilitate the surveying and selling of the same."221 "As these important objects continue to require the aid of the troops," said the punctilious President, "it is necessary that the establishment thereof ... be conformed by law to the constitution of the United States. ${ }^{3222}$

Congress promptly obliged, ratifying the previous establishment in all respects save the mode of appointing the officers (which was now governed by Article II), prescribing the form of the oath that may have been required by Article VI, ${ }^{223}$ and-in response to another request by the President-authorizing him to call out "such part of the militia ... as he may judge necessary" in order to protect against Indians on the frontier, as authorized by Article I. ${ }^{224}$

Protecting the frontier was the principal purpose for which Washington had requested authorization to keep the regular troops as well, yet the statute was notably silent about the purposes for which the soldiers might be employed. Maybe Congress thought approval of the original establishment implied endorsement of its purposes; maybe the members believed that once they had raised troops pursuant to Article I, $\S 8$ it was up to the President as Commander-in-Chief to decide what to do with them ${ }^{225}$-subject of course to whatever limitation might be im-

221 Annals at 715.

222 Id. See also 6 Doc Hist at 1995-98.

${ }_{223} 1$ Stat 95, $96 \$ 3$ (Sept 29, 1789). It was not clear whether army officers were "executive officers" within the meaning of Article VI, and the statutory oath was required even of privates, who might not qualify as "officers" at all. It would not be difficult to conclude that for all military personnel an oath to support the Constitution was necessary and proper to the raising of troops or the governance of the army.

22. 1 Stat at 96 \$; 6 Doc Hist at 1999; US Const, Art I, § 8, cl 15 ('The Congress shall have power... To provide for calling forth the militia to execute the laws of the Union, suppress insurrections and repel invasions."). Note the breadth of discretion given the President-unavoidably-by this provision.

${ }^{223}$ See 1 Annals at 724 (Rep Madison) ("By the constitution, the President has the power of employing these troops in the protection of those parts [of the frontiers] which he thinks requires [sic] them most."). Accord Quincy Wright, The Control of American Foreign Relations 193-94 (MacMillan, 1922). Contrast Louis Henkin, Constitutionalism, Democracy, and Foreign Affairs 26 (Columbia, 1990) ("The President's designation as 
plicit in Article I's reservation to Congress of the power to declare war. 226

The 1789 legislation was obviously a temporary expedient, and in the following session Congress enacted a more comprehensive measure providing for a permanent military establishment. ${ }^{227}$ In light of deteriorating relations with the Creek Indians, ${ }^{228}$ the number of troops was increased to more than 1200 "able-bodied men, not under five feet six inches in height," and between 18 and 46 years of age. ${ }^{229}$ The statute divided them into regiments and battalions, regulated their pay and rations, and provided pensions for the wounded-all of which was plainly necessary and proper to the raising and support of armies. ${ }^{230}$ As under the 1789 statute, the Articles of War adopted under the Confederation were to govern until altered by Congress-but only insofar as they were consistent with the new Constitution. ${ }^{231}$

The most intriguing section of the 1790 Act was the last, which echoed the militia provision of its predecessor with one important difference: Now the President was empowered to call out the militia for the purpose of aiding the troops in protecting the frontiers. ${ }^{232}$ The new phrasing was manifestly drafted in response to Secretary Knox's unequivocal recommendation that the regulars bear the principal burden of frontier defense: "The

Commander in Chief [ ] appears to have implied no substantive authority to use the armed forces, whether for war (unless the United States were suddenly attacked) or for peacetime purposes, except as Congress directed.").

${ }_{226}$ See US Const, Art I, § 8, cl 11; Art II, § 2, cl 1 .

2271 Stat 119 (April 30, 1790). There was no reported discussion of this bill; much of the House debate was in secret. See 5 Doc Hist at 1278.

${ }_{223}$ See the report of Secretary Knox. 5 Doc Hist at 1279-80.

2291 Stat $119 \S \S 1,2$. It did not seem to occur to anyone to suggest that any of these restrictions offended the "equal protection component" that modern wizards have conjured into the Due Process Clause of the Fifth Amendment that Congress had proposed in 1789. See, for example, Bolling $v$ Sharpe, 347 US 497, 499 (1954); The Second Century at 37879.

230 1 Stat at 119-21 §§ 3-11. Pensions were to be paid "at such rate ... and under such regulations as ... directed by the President," but no more than half the normal pay. Id at 121 § 11. Once again significant discretion was conferred upon the President. Contrast once more the cramped interpretation of the Commerce Clause with respect to railroad workers' pensions in Railroad Retirement Board v Alton Railroad, 295 US 330 (1935). See text accompanying note 92.

${ }_{231} 1$ Stat at $121 \S 13$. Art I, \& 8, cl 14 empowers Congress "[t]o make rules for the government and regulation of the land and naval forces." Section 12 continued the oath requirement of the 1789 law. 1 Stat at 121, §12.

${ }^{232} 1$ Stat at $121 \S 16$. A separate bill for the uniform organization of the militia was hotly debated in the waning days of the First Congress but was not adopted until the Second. Discussion of the serious constitutional problems raised by the militia bill will therefore be deferred. See generally 2 Annals at 1851-75; 1 Stat 271 (May 8, 1792). 
oeconomy of disciplined troops is always superior to militia while their efficacy is at least equal."233

Once again there was no doubt that the reason for raising additional soldiers was to protect against Indian depredations, ${ }^{234}$ and this time Maclay confided to his diary that he thought this purpose illegitimate. Armies were meant "for the Annoyance of an Enemy in their own Country"; Article I left the enforcement of laws, the suppression of insurrections, and the repulsion of invasions to the militia. ${ }^{235}$ Congress was unimpressed by this contention, and the text hardly supports it; the militia provision can as easily be interpreted to permit the supplementary use of militia, and it would have been odd to forbid raising regular troops in a case of actual invasion.

More interesting was Maclay's related conclusion that the Constitution permitted no troops to be "kept up in peace."236 Whether the country was at peace at the time might have been disputed in view of the Indian raids that had prompted the President to seek legislation, but it was true that war had not been declared. Maclay appeared to be suggesting that Congress could not constitutionally raise troops until it had taken the more drastic step of declaring war.

Stated this baldly, the argument seems quite wrong; one would not expect the Framers to require the country to leap into war before preparing for it. ${ }^{237}$ Perhaps in saying troops should not be "kept up" in peace Maclay meant only that there could be no "Standing Army," for which he feared the bill would "lay[ ] the foundation." ${ }^{238}$ Standing armies had been a popular bugaboo of the Anti-Federalists, who had proposed to restrict them by constitutional amendment. ${ }^{239}$ The Ninth Amendment stands as a per-

233 See 5 Doc Hist at 1281.

234 See id at 1279-82. Knox had asked for an army of 5,000 men in order "to be in a situation to punish all unprovoked aggressions" by the Creeks and if necessary "to march into their country and destroy their Towns." Id at 1280 . He did not say whether he thought that once the troops were in place all this could be done without a declaration of war or other specific authorization by Congress. See id at 1356.

235 Doc Hist at 230-31.

236 Id at 231.

237 See Federalist 25 (Hamilton), in The Federalist Papers at 161 (cited in note 36) (deriding the prospect of "a nation incapacitated by its constitution to prepare for defence, before it was actually invaded").

${ }^{238} 9$ Doc Hist at 230-31.

230 See 4 Doc Hist at 15 (New Hampshire), 17 (Virginia), 20 (New York). Burke of South Carolina offered an amendment in the House that would have required both "necessity" and a two-thirds vote for a standing army in peacetime, but it was defeated. 1 Annals at 780-81. 
petual warning against interpreting even the adoption of a limitation as implying the existence of congressional power, ${ }^{240}$ but supporters of the Constitution had made quite clear that they understood it to permit the creation of a permanent military establishment. It was enough, Hamilton had written, that armies could not be raised or money expended for their support without statutory authority, and that even statutory appropriations for military purposes could not last longer than two years. ${ }^{241}$

Like its predecessor, the 1790 statute gave the President no express authority to employ the army to protect the frontiers. At the same time, the last section plainly assumed that the President already had that power. Since this time nothing was said about those resolutions of the Confederation Congress, the inference is strong that Congress thought the requisite authority inherent in the office of Commander-in-Chief. ${ }^{242}$

Moreover, both Secretary Knox and Washington himself seemed to think this authority extended to offensive operations undertaken in retaliation for Indian atrocities. Not long after enactment of the 1790 statute the President, without further congressional sanction, directed General Harmar to develop a plan employing both regular troops and militia to "extirpate" a band of marauders in the Northwest Territory. ${ }^{243}$ As the Secretary later explained to Governor St. Clair, the aim of this expedition was to destroy the "Towns and Crops" of the Wabash Indians in order to exhibit our power to punish them for their depredations. ${ }^{244}$

The operation was carried out, with heavy casualties. ${ }^{245}$

240 See The First Hundred Years at 48-49, discussing Calder v Bull, 3 US 386 (1798).

241 Federalist 24-29, in The Federalist Papers (cited in note 36). See, for example, Federalist 28 at 178: "Independent of all other reasonings upon the subject, it is a full answer to those who require a more peremptory provision against military establishments in time of peace, that the whole power of the proposed government is to be in the hands of representatives of the people." Hamilton had specifically envisioned the continuing necessity "for keeping small garrisons" of regular troops "on our western frontier" for the very purposes proposed by Washington. Federalist 24 at 156.

${ }_{242}$ Indeed the formulation of $\$ 16$ is reminiscent of the provision concerning removal of the Secretary of Foreign Affairs, which was placed in the passive voice in order, as its sponsor argued, to avoid any implication that the authority was for Congress to confer or withhold. See 1 Annals at 525-27 (Rep Benson). Some 900 additional troops were authorized the following year to reinforce the Southwest frontier; once again there was no express authority to employ the new troops for their intended purpose. 1 Stat 222 (Mar 3, 1791); House Committee Report, 5 Doc Hist at 1422 (Feb 1, 1791).

${ }^{243}$ See Letter of Secretary Knox to General Harmar, June 7, 1790, in 5 Doc Hist at 1348-50.

${ }^{24}$ Letter of Secretary Knox to Governor St. Clair, Sept 12, 1790, in 5 Doc Hist at 1355, 1356.

${ }^{245}$ See Letter of General Harmar to Secretary Knox, Nov 4, 1790, in 5 Doc Hist at 
Maclay thought the President had exceeded his powers: "A War has been actually undertaken against the Wabash Indians, without any Authority of Congress .... ."246 We were to hear much more both of expeditions to chastise the Northwest Indians and of the division of military authority between Congress and the Commander-in-Chief. ${ }^{247}$

\section{B. Indians}

The explosive confrontation between indigenous warriors and encroaching settlers along the western frontier was the proximate cause of the various military measures already discussed. It also gave rise during the First Congress to a series of treaties and statutes specifically directed to Indian relations.

The Fort Harmar Treaty with the Wyandots and other northwestern tribes, which the Senate approved in $1789,{ }^{248}$ confirmed the boundary between the United States and Indian country along the shore of Lake Erie and the release of Indian claims to lands east, south, and west of that boundary in exchange for peace and goods. ${ }^{249}$ Article $\mathrm{V}$ of the treaty required the Indian nations to deliver up any of their members who robbed or killed a citizen of the United States and in exchange promised to punish in accord with "the laws of the state or of the territory wherein the offence was committed" any citizen who robbed or killed an Indian, in order "that nothing may interrupt the peace and har-

1359; James Ripley Jacobs, The Beginning of the U.S. Army: 1783-1812 53-63 (Princeton, 1947) (presenting the expedition as a pathetic failure). President Washington informed Congress of this expedition (but not of its outcome) in his Annual Message of December 8, 1790. 2 Annals at $1770,1771-72$.

248 9 Doc Hist at 340.

247 The First Congress also authorized the President to purchase land at West Point on the Hudson River for the construction of a fort. 1 Stat 129 (July 5, 1790). Art I, § 8, cl 17 envisioned exclusive federal authority over lands "purchased [for such purposes] by the consent" of the state in which they were located, but West Point was to be purchased from a private individual who had petitioned Congress for compensation after the Government occupied his property. See 6 Doc Hist at 2059-60. Plainly enough the statute was necessary and proper to national defense in view of the strategic importance of navigation on the river. See Report of the Secretary of the Treasury of June 10, 1790, 6 Doc Hist at 2060-62. Just as plainly Congress did not view the cession procedure of Art I \& 8 as the only means of acquiring land; state consent was required only to oust state jurisdiction entirely.

248 Stat 28 (Jan 9, 1789).

249 7 Stat at 28-29, Art II. The Confederation Congress, Secretary Knox explained, had originally assumed that the peace treaty with Great Britain had given us title to lands in the Northwest Territories, but the Fort Harmar treaties acknowledged that we had acquired only sovereignty and that the land had to be purchased from the Indians. See 1 American State Papers (Indian Affairs) 7 (Gales \& Seaton, 1832). 
mony now established between the United States and said nations." ${ }^{\text {250 }}$ Article VII provided that "[t]rade sh[ould] be opened with the said nations" but added that no one should be permitted to trade with them without a license, "to the end that they may not be imposed upon in their traffick."251

The treaty concluded with the Creek Nation in 1790 was similar in many respects. ${ }^{252}$ Instead of providing for licensed traders, however, it declared that no citizen of the United States should enter Creek territory without a passport and that anyone attempting to settle on Creek lands would "forfeit the protection of the United States. ${ }^{\text {253 }}$ Finally, the United States promised to provide the Creeks "from time to time" with "domestic animals and instruments of husbandry," in order "[t]hat the Creek nation may be led to a greater degree of civilization, and to become herdsmen and cultivators, instead of remaining in a state of hunters."254 Encouraging Indians to practice domestic arts, Knox argued, would be better than suppressing them by force. ${ }^{255}$

Both Georgia Senators voted against the Creek Treaty, ${ }^{256}$ and Georgia Representative James Jackson assailed it in the House on the ground that it ceded away without compensation "more than three million acres of land ... guarantied to that State by the Constitution of the United States." 257 Explicitly invoking "those parts" of the document "which secure to every citizen the rights of property," ${ }^{\prime 258}$ he seemed also to anticipate the Supreme Court's later dictum that the treaty power did not include authority to cede territory within a state without its consent. ${ }^{259}$ The House had no say in the formation of treaties, how-

2507 Stat at 29.

2517 Stat at 30 . See also the report of the Commissioners appointed to negotiate with the Creeks, 1 American State Papers (Indian Affairs) at 79 (cited in note 249), urging licensing to avoid the risk that unscrupulous traders might antagonize the Indians.

2527 Stat 35 (Aug 7, 1790).

${ }_{253} 7$ Stat at 36-37, Art VI, VII. As Washington informed the Senate, commerce with the Creeks at the time was "almost exclusively in the hands of a company of British merchants," and the Senators consented in advance to a secret article providing for an orderly transition to commerce through ports of the United States. 1 Annals at 1063-64.

2547 Stat at 37, Art XII.

255 Letter to President Washington, July 28, 1789, in 1 American State Papers (Indian Affairs) at 33 (cited in note 249).

256 The vote was 15 to 4; the other dissenters were Butler (South Carolina) and Walker (Virginia). See 1 Annals at 1074.

2572 Annals at 1839.

258 Id.

${ }^{259}$ Geofroy $v$ Riggs, 133 US 258, 267 (1890). 
ever, and nothing came of Jackson's arguments. The cession of territory was a common subject of treaties; and as Knox's earlier report had made clear, what the treaty confirmed to the Creeks was title, not sovereignty. A treaty giving privately-owned land to the Indians might well have triggered compensation once the Fifth Amendment was ratified; but it is not clear that either the President or the Senate agreed with Jackson's characterization of the facts. ${ }^{260}$

In July 1790, shortly before conclusion of the Creek Treaty, Congress had passed a law "to regulate trade and intercourse with the Indian tribes." ${ }^{3261}$ Section 1 of this statute provided that no person should carry on such trade without a license and required posting of a bond to ensure compliance with "such rules and regulations as the President sh[ould] prescribe." Not only did the licensing and bonding requirements plainly regulate "commerce ... with the Indian tribes" as authorized by Article I, § 8; they were just as plainly necessary and proper to implement the corresponding terms of the treaty with the Northwest Indians. ${ }^{262}$ Most startling from the perspective of the late twentieth century is the breadth of rulemaking power given to the President, which seemed to delegate to him virtually all of Congress's own authority over Indian commerce. ${ }^{263}$

Section 5 provided that any citizen or inhabitant of the United States who committed a crime against an Indian in Indian country should be "subject to the same punishment" as if the offense had been committed in the United States. ${ }^{264}$ Reading this statute in isolation might suggest that the First Congress took quite a broad view of its responsibility to regulate Indian "commerce." Yet the Fort Harmar treaty had promised the Indians the very protection afforded by $\S 5$; this statutory provision too was necessary and proper to carry out the treaty.

250 In other respects both treaties seemed to fit comfortably within traditional conceptions of the treaty power, as their provisions plainly promoted amicable relations with Indian nations and were reasonably related to national defense.

261 Stat 137 (July 22, 1790).

202 Section 2 of the statute provided for revocation of licenses for violation of the regulations, subject to later judicial review. Evidently Congress thought that to take first and litigate afterwards was consistent in this context with the Due Process Clause of the constitutional amendment it had just proposed. See US Const, Amend V.

203 Section 1 also empowered the President to dispense with the license requirement in the case of tribes "surrounded in their settlements by the citizens of the United States, ... if he may deem it proper." No standards were set to guide the exercise of this discretionary power. Compare Panama Refining Co. v Ryan, 293 US 388, 414-20 (1935); The Second Century at 216-18.

2351 Stat at $138, \S 5$. 
Within the states, of course, criminal offenses were basically a matter of state law. The statute did not clearly say whether offenders were to be subject to state or to federal prosecution, though the provision that they were to be "proceeded against in the same manner as if the offence had been committed within the jurisdiction of the state or district" arguably suggested the former. ${ }^{265}$ In either case, Congress appeared to have made it a federal offense to do in Indian territory what state law forbade within the states. In so doing, it seemed once again to have made the content of federal law dependent on the future acts of the states $^{266}$ and-if the assumption of state prosecution is correct-to have co-opted state officers to enforce federal law as well. ${ }^{267}$ To modern eyes these provisions raise interesting issues of federalism; it may be significant that the First Congress perceived no constitutional problem.

\section{Pirates}

In his Annual Message at the beginning of the second session, President Washington called the attention of Congress to the "distressful" state of trade between the United States and the Mediterranean, adding that "you will not think any deliberations misemployed which may lead to its relief and protection."268 What this meant was spelled out a few days later in a report from Secretary of State Jefferson to both Houses. ${ }^{269}$ Repeated captures of American vessels and seamen by Algerian pirates had prevented resumption of a Mediterranean trade that had flourished before the Revolution; it was for Congress to decide whether the appropriate response was tribute, ransom, or war.

A Senate committee responded at once by recommending the establishment of a navy to protect Mediterranean trade as soon as the state of the Treasury allowed. ${ }^{270}$ In the meantime the

265 Id.

266 See text accompanying notes 76-86 (discussing the inspection law).

267 The alternative conclusion that Congress had required state legislatures to punish crimes in Indian country would pose equally troubling questions of federalism. See note 93.

${ }^{268}$ See 2 Annals at 1770, 1772 (Dec 8, 1790).

${ }^{269} 1$ American State Papers (Foreign Relations) 104-08 (Gales \& Seaton, 1832). See also Jefferson's separate report in response to a petition for the relief of hostages taken by the Barbary Pirates and the President's accompanying letter inviting Congress to "provide on their behalf, what to you shall seem most expedient." Id at 100-04.

270 Id at 108. Maclay assailed this proposal as a plot to start yet another war and suggested it would be better to spend $\$ 35,000$ for ransom than $\$ 500,000$ to build a fleet. 9 Doc Hist at 373 . Since he was talking only to his diary, there was no one to remind him 
Senate gave advice and consent in advance "that the President ... take such measures as he may think necessary for the redemption of the citizens of the United States now in captivity at Algiers, provided the expense shall not exceed forty thousand dollars. ${ }^{\text {"271 }}$ Appropriately, Washington replied that he would ransom the prisoners "so soon as the moneys necessary shall be appropriated by the Legislature."272

Appropriations could be made only by statute, and it would not be long before a request for money to implement a treaty would kindle a great debate over the freedom of the House to withhold its consent. ${ }^{273}$ For the moment, however, any such confrontation was postponed by the Senate's agreement to delay any ransom attempt "until the situation of the Treasury shall more clearly authorize appropriations for that purpose, in light of the large appropriations that had been made for the protection of the Western frontiers." 274

As Gerhard Casper has observed, both Washington and Jefferson plainly assumed that Congress's powers over appropriations and war gave it ultimate authority to resolve the Algerian controversy, notwithstanding the President's much vaunted responsibility for foreign affairs. ${ }^{275}$

that if we didn't build a navy this might not be the last $\$ 35,000$ we would have to pay.

2712 Annals at 1795-96. Since such an exchange would presumably take the form of an international agreement, there was nothing particularly startling in the assumption that this subject fell within the Senate's special authority with respect to foreign affairs. See US Const, Art II, § 2, cl 2.

272 Annals at 1806.

273 See Miller, The Federalist Era at 192 (cited in note 7) (discussing Jay's treaty).

2742 Annals at 1825 (March 3, 1791). See also Roy Swanstrom, The United States Senate, 1787-1801 120, reprinted as S Doc No 100-31 (1988) (suggesting that the true explanation for the Senate's action was its unwillingness "to ask the House of Representatives for advance appropriations and thereby admit that House into a participation in the treaty power"). As Washington had requested, however, Congress did appropriate a sum not to exceed $\$ 20,000$ "for the purpose of effecting a recognition of the treaty of the United States, with the new emperor of Morocco." 1 Stat 214 (March 3, 1791). That treaty, which dated from 1787, required among other things that the emperor set free any Americans captured by Moors. See 8 Stat 100, 101, Art VI (Jan 1787). Why it might require $\$ 20,000$ to induce the emperor to recognize his obligations was not explained. The President said only that the appropriation was of "importance... to the liberty and property of our citizens," and Congress evidently thought it necessary and proper to effectuating the treaty. See 2 Annals at 1806. See also Gerhard Casper, An Essay in Separation of Powers: Some Early Versions and Practices, 30 Wm \& Mary L Rev 211, 246 (1989) (explaining that "the Sultan had died and a customary payment was due his successor").

${ }^{275}$ See Casper, $30 \mathrm{Wm}$ \& Mary L Rev at 246. 


\section{MisceLLANY}

After setting up and financing the new government, and before tackling such critical issues as national defense and the bank, Congress somehow found time to exercise a number of the more mundane powers entrusted it by the Constitution. The second session of the First Congress produced comprehensive legislation on naturalization, patents, copyrights, and crimes. Other legislation of the period dealt with such matters as full faith and credit, the admission of new states, the territories, and the seat of government.

\section{A. Naturalization}

"The Congress shall have power," says Article I, § 8, "[t]o establish an uniform rule of naturalization." On the strength of this authorization Congress enacted a naturalization law in March $1790 .{ }^{276}$

The statute provided that any "free white" alien having resided in the United States for two years could become a citizen upon proving "good character" and promising "to support the constitution." "277 By excluding applicants who did not meet these qualifications Congress demonstrated that, as in the case of taxes, it understood the uniformity requirement solely in geographic terms. ${ }^{278}$ The history of the constitutional provision confirms this conclusion; Congress was given power to adopt a nationwide rule in order to prevent a state with lenient naturalization requirements from foisting off undesirables on other states under the Privileges and Immunities Clause. ${ }^{279}$

In light of this history, Representative Sherman urged that the bill be amended to preclude naturalization of Tory emigrants

276 I Stat 103 (March 26, 1790).

277 Id. 51-57.

278 See the discussion of the analogous tax question in the text accompanying notes

279 See Story, Commentaries $\$ 537$ (cited in note 15); James Kent, Commentaries on American Law 397 (Da Capo, 1971) (first published 1826); Agrippa, Letter No 9, Dec 28, 1787, Massachusetts Gazette, in Philip B. Kurland and Ralph Lerner, eds, 2 The Founders' Constitution at 559-60 (Chicago, 1987) (citing Pennsylvania as the most notorious source of infection); William Rawle, A View of the Constitution of the United States of America 84-85 (Philip H. Nicklin, 2d ed 1829), in Founders' Constitution at 606. Like the provision limiting military service to males, see text accompanying note 229 , the exclusion of non-whites suggests that Congress did not understand the Due Process Clause that it had just proposed to contain a general ban on racial discrimination, at least when no life, liberty, or property in the traditional sense was at stake. 
and paupers: The constitutional provision was "meant to guard against an improper mode of naturalization, rather than foreigners should be received upon easier terms than those adopted by the several States. ${ }^{280}$ Like the related argument that the commerce power could be employed only to remove obstructions to commerce, this objection got nowhere at the constitutional level, ${ }^{281}$ but the historical purpose of the Naturalization Clause was to play an important part in the later controversy over whether the federal power to grant citizenship was exclusive. ${ }^{282}$

Much of the House debate on naturalization revolved around a provision of the original bill that would have subjected naturalized citizens to an additional residence requirement before they became eligible to hold federal or state office. ${ }^{283}$ Laurance understandably doubted whether Congress had authority to add to the qualifications specified for federal legislators in Article I or to tell the states who was entitled to participate in their government. ${ }^{284}$ Congress's sole power, Stone added, was to confer citizenship; it was for the states to define the rights of citizens. ${ }^{285}$ Jackson responded with a quotation from Blackstone in support of the practice of admitting foreigners to citizenship "progressively," implying that precedents from "that nation from which we derive most of our ideas on this subject" were highly relevant in interpreting the Constitution. ${ }^{286}$ The additional residence requirement was dropped from the bill-whether on constitutional or policy grounds we do not know.

More interesting still was the further provision declaring that "the children of citizens of the United States, that may be born beyond sea, or out of the limits of the United States, shall

2801 Annals at 1148.

281 However, the bill was amended to require state consent to the naturalization of any person "heretofore proscribed by any state." See 1 Stat at 104.

${ }_{282}$ See Collet $v$ Collet, 6 F Cases 105, 106 (CCD Pa 1792) (No 3001) (held not exclusive); United States $v$ Villato, 28 F Cases 377, 379 (CCD Pa 1797) (No 16,622) (described, in dicta, as exclusive).

283 Annals at 1147.

284 Id at 1149. Congress had already required that the Attorney General and U.S. Attorneys be lawyers, 1 Stat 73, 92-93 $\& 35$ (Sept 24, 1789), but the Constitution was silent as to their qualifications. Consider Powell v McCormack, 395 US 486, 550 (1969); Bond $v$ Floyd, 385 US 116, 132-33 (1966); The Second Century at 442-44, 439-40. But see Edward S. Corwin, The President: Offices and Powers, 1787-1957 33 (NYU, 4th ed 1957) (noting that a variety of federal statutes disqualified criminal offenders from all federal offices).

28s 1 Annals at 1156-57.

${ }^{286}$ Id at 1158. See also id at 1155 (Rep Tucker) (taking the constitutional requirements for members of Congress as evidence that Congress could "make the admission to citizenship progressive"). 
be considered as natural born citizens"-provided only that their fathers at some point had resided in the United States. ${ }^{287}$ Representative Burke had explained to the House that a similar provision had been made in England, but he did not identify the source of congressional authority. ${ }^{288}$ In accepting his suggestion, Congress appears to have interpreted the authority to enact "naturalization" laws to give it a general power to define or confer citizenship ${ }^{289}$-a power that Burke might have thought twice before advocating had he stopped to consider its possible applicability to the numerous individuals euphemistically described in Article IV, $\S 2$ as "persons held to service or labor" in his own state of South Carolina. ${ }^{290}$

Finally, and perhaps most surprisingly from a modern perspective, the statute made naturalization a judicial rather than an executive function. Application was to be made "to any common law court of record" in a state where the applicant had lived. ${ }^{291}$ The Act did not specify whether federal courts were included. The terminology was broad enough to include them, but there was no explicit grant of federal jurisdiction; and the Judiciary Act contained no general federal-question provision. ${ }^{292}$ To open federal courts to ex parte naturalization petitions would raise the difficult question whether these proceedings fell within Article III's grant of judicial power to decide only "cases" and "controversies";

2871 Stat at 104.

2881 Annals at 1160.

289 But see Corwin, The President at 33 (cited in note 284) ("The provision must undoubtedly be referred to the proposition that, as the legislative body of a nation sovereign at international law, Congress is entitled to determine who shall and who shall not be admitted to the body politic."). Compare The Chinese Exclusion Case, 130 US 581, 606 (1889) (holding Congress may exclude foreigners from the United States); The Second Century at 14-15.

${ }^{200}$ See text accompanying notes 94-111 (discussing Southern fears of congressional efforts to emancipate the slaves); Dred Scott $v$ Sandford, 60 US 393, 405-07 (1857) (holding the naturalization power limited to cases involving foreigners). In the debate over the eligibility of Burke's colleague William Smith for election to Congress, the consensus had seemed to be that state law determined citizenship in the first instance, but that was not inconsistent with a congressional power to provide otherwise by statute. See 1 Annals at 149, 175, 342-43, 412-25; M. St. Clair Clarke and David A. Hall, compilers, Cases of Contested Elections in Congress from the Year 1789 to 1834, Inclusive 23-37 (Gales \& Seaton, 1834). In urging the House to add a provision permitting aliens to hold property, Representative Clymer seemed to suggest that the Naturalization Clause gave Congress a more general authority to regulate the legal status of aliens-a preview of yet another epic controversy that would divide Congress in the next few years. See 1 Annals at 1159-60; Alien Act, 1 Stat 577 (July 6, 1798).

2911 Stat at 103.

292 Judiciary Act, 1 Stat 73, 76-79 \$§ 9-12 (Sep 24, 1789).

${ }^{293}$ See Tutun v United States, 270 US 568, 576-78 (1926); The Second Century at 182- 
agencies to enforce federal law. ${ }^{294}$ There is no evidence that the First Congress was troubled by either of these concerns.

\section{B. Patents and Copyrights}

Barely two weeks after having achieved a quorum, the House received petitions for special legislation granting exclusive rights to publish two books and to exploit scientific discoveries relating to the magnetic pole. ${ }^{295}$ There was no doubt that Congress had power to grant these requests, for Article I, \& 8 authorized it " [t]o promote the progress of science and useful arts, by securing, for limited times, to authors and inventors, the exclusive right to their respective writings and discoveries." In fact a House committee promptly recommended that Congress pass a law securing to the second petitioner "the exclusive pecuniary emolument to be derived from the publication of [his] several inventions."296

However, it was not to be. When Washington in his Annual Message the next January urged the legislators to give "effectual encouragement" to "useful inventions, ${ }^{\text {,297 }}$ they responded by authorizing a panel composed of the Attorney General and the Secretaries of State and War to grant a patent for any "invention or discovery" they might deem "sufficiently useful or important."298 The initial trickle of individual requests had evidently alerted Congress to the inundation it faced if it attempted to grant patents and copyrights by private bill. ${ }^{299}$ The discretion delegated was broad but not unrestricted; nobody seems to have thought that Article I required Congress to pass upon individual patent applications. ${ }^{300}$

83.

294 See note 93 and the text accompanying note 265 .

206 See the House Journal in 3 Doc Hist at 22 (April 15, 1789).

206 See 1 Annals at 178.

297 Id at 970.

2881 Stat 109, $110 \S 1$ (Apr 10, 1790). Faithful to the constitutional injunction that the rights conferred be "for limited times," the statute provided that patents should be issued "for any term not exceeding fourteen years." Id.

299 See 1 Annals at 985-88, tabling a bill to grant an individual patent pending enactment of a general patent law. Compare Sedgwick's apt objection to the analogous practice of granting individual plots of western land by private bill: "[W]e shall be perpetually employed in a menial business, and which we are greatly incompetent to." 1 Annals at 1109. See also note 424 . Similar complaints were made with respect to individual claims against the government. See Gazette of the United States (Mar 13, 1790) (Rep Bland); New York Daily Gazette (Mar 15, 1790) (Reps Bland and Boudinot).

${ }_{300}$ On the other hand, despite Marshall's later insistence that the sole province of legislation was "to prescribe general rules for the government of society," Fletcher $v$ Peck, 10 US 87, 136 (1810), no one seemed to doubt Congress's power to grant individual 
In contrast to the arguably analogous power to confer citizenship, ${ }^{301}$ the authority to grant patents was given to executive officers rather than to the courts. The district court, however, was empowered upon motion to set aside any patent "obtained surreptitiously by, or upon false suggestion." doubt that this proceeding was properly judicial, since it involved a concrete dispute between adversary parties. There was little doubt that it was properly federal, since the validity of a patent was a federal question. ${ }^{303}$ Congress apparently felt no constitutional compulsion to provide judicial review of the determination whether the invention was "sufficiently useful and important," for it provided none; and it seems to have concluded that the constitutional amendment it had just proposed would not require a jury in such actions, for a jury-trial provision had been deleted in the House after it was suggested that jurors would not be competent to pass on the technical questions involved. ${ }^{304}$

Section 4 provided that infringers should both pay damages and forfeit the offending goods. ${ }^{305}$ Nothing was said about the courts in which infringement actions were to be brought, and no other statute provided for federal jurisdiction in the absence of diverse citizenship. Obviously Congress anticipated that state courts would hear them; it did not say they had to. This time, however, the statute expressly provided for jury trial, raising the serious question whether Congress could constitutionally regulate the procedure of state courts enforcing federal law..$^{306}$

patents. Indeed the First Congress enacted several private bills providing for the payment of individual claims or pensions and the remission of individual penalties or duties. See 6 Stat 1-3. See also White, The Federalists at 79 (cited in note 13) ("While in general Congress tended to legislate on broad matters of policy, it did nevertheless insist on dealing with some matters which would now be recognized as falling in the proper field of administrative discretion.").

${ }^{301}$ See text accompanying notes 291-94.

${ }^{302} 1$ Stat at $111 \S 5$.

303 See US Const, Art III, § 2, cl 1. Arguably, however, the federal question arose only by way of defense to a complaint seeking to establish the common law right to exploit the invention. See Louisville \& Nashville R.R. v Mottley, 211 US 149, 152 (1908). The reference to the "district court" seemed to suggest federal jurisdiction, although the statute did not say so expressly.

${ }^{304}$ See 2 Annals at 1463-64. This was the sole issue on which debate on the patent bill was reported.

${ }_{305} 1$ Stat at 111.

${ }^{306}$ For the modern view, see Dice $v$ Akron, Canton \& Youngstown Railroad Co., 342 US 359, 363 (1952). Compare the question whether Congress could require state courts to act at all, discussed in note 93 and the text accompanying notes 265 and 294. 
A few weeks after passing the patent law, Congress enacted a comparable statute providing for the issuance of copyrights. ${ }^{307}$ In extending protection to "map[s]" and "chart[s]" as well as books, this law seemed to reflect a rather generous if appropriate interpretation of the constitutional term "writings." because there was no requirement in the copyright law that the author's work be "useful and important," there was no provision for executive determination whether the statutory requirements had been met. ${ }^{309}$ All the applicant had to do was to deposit copies of his work "in the clerk's office of the district court" and with the Secretary of State, ${ }^{310}$ for purposes of public notice. Evidently Congress perceived no constitutional impediment to this convenient use of judicial officers for purely administrative purposes. ${ }^{311}$

As in the patent law, infringement actions were authorized, this time "in any court of record in the United States, wherein the [action] is cognizable. ${ }^{n 312}$ Again there was no provision for federal jurisdiction, and this time nothing was said about jury trial. An interesting provision near the end of the statute added a damage remedy against anyone who should "print or publish any manuscript" without the author's consent. ${ }^{313}$ Since remedies had already been provided for infringement of copyrights obtained by depositing books or maps with the district court, the additional provision respecting "manuscript[s]" must have been intended to protect authors who had not yet completed the statutory formalities. Protection before deposit was plainly appropriate to promoting the progress of the arts, but one might wonder whether the apparently eternal protection afforded to "manuscript[s]" was consistent with the constitutional require-

3071 Stat 124 (May 31, 1790). There was no reported debate on this bill.

308 Id at $\S 1$. The fluidity of the boundary between "writings" and "discoveries," and thus between copyrights and patents under the statutory scheme, was suggested by the fact that one of the first petitions presented to Congress requested exclusive rights to sell "maps, charts, and tables" based on the "principles of magnetism" whose explanation the applicant had allegedly "invented." 3 Doc Hist at 22.

${ }^{300}$ Contrast the patent law, discussed in the text accompanying notes 295-306.

3101 Stat at $125 \$ \$ 3,4$.

311 Compare the advisory fact-finding duties (respecting the mitigation of certain penalties) that the First Congress entrusted to federal judges, whom Article III seems to limit to deciding specified types of "cases" and "controversies." 1 Stat 122-23 § 1 (May 26, 1790).

3121 Stat at $124-25 \$ 2$.

${ }^{313} 1$ Stat at $125-26 \S 6$. This remedy too was to be sought in "any court having cognizance thereof." Id. 
ment that Congress confer exclusive rights only "for limited times."314

As noted above, the petition requesting protection for discoveries respecting the magnetic pole also requested "the patronage of Congress" for a "voyage to Baffin's Bay ... to ascertain the causes" of the variations that had been observed. ${ }^{315}$ Tucker doubted "whether the Legislature ha[d] power, by the Constitution, to go further in rewarding the inventors of useful machines, or discoveries in sciences, than merely to secure to them for a time the right of making, publishing and vending them." There may have been other bases of congressional authority to finance the proposed expedition, but Tucker was right about the Patent Clause; the Constitution confers not a general power to "promote the progress of science and useful arts," but only the power to grant limited exclusive rights in order to accomplish that goal. ${ }^{317}$

\section{Crimes}

On April 30, 1789, Congress enacted a comprehensive statute defining an impressive variety of federal crimes. ${ }^{318}$ As in the case of patents and copyrights, there was little reported debate; yet the statute itself resolved a number of interesting constitutional questions.

Criminal law in general was not a federal subject. Article III, $\S 3$ defined treason restrictively and authorized Congress to "de-

314 If the answer is that Congress did not confer this protection but merely provided a remedy for violation of common-law copyright, that raises constitutional questions of its own. Perhaps the clue lies in the term "manuscript": The exclusive right to publish a work could be obtained only by following the statutory procedure, and then the right was limited to a renewable term of 14 years. 1 Stat at $124 \S 1$. For some policy dimensions of copyright in unpublished works, see William M. Landes, Copyright Protection of Letters, Diaries, and Other Unpublished Works: An Economic Approach, $21 \mathrm{~J}$ Legal Stud 79 (1992).

${ }^{315}$ See 3 Doc Hist at 22; text accompanying notes 130-35.

3161 Annals at 180.

317 Thus while Washington had urged Congress to encourage not only domestic invention but also "the introduction of new and useful inventions from abroad," 1 Annals at 970 , even Hamilton had to concede that Congress's authority to give exclusive privileges to "Introducers" of valuable improvements was "not without a question." Report on Manufactures, 10 Hamilton Papers at 230, 308 (cited in note 48). See also the exchange of letters between Madison and Tench Coxe on the question whether Congress could employ the proceeds of Western land sales for this purpose, 13 Madison Papers at 111, 113 (Coxe, Mar 21, 1790), 128-30 (Madison, Mar 28, 1790), 130-31 (Coxe, Mar 31, 1790) (cited in note 1).

3181 Stat 112. 
clare" its "punishment." Article I, § 8 empowered Congress to provide for the punishment of "counterfeiting the securities and current coin of the United States," "piracies and felonies committed on the high seas," and "offenses against the law of nations," as well as conferring the power of "exclusive legislation" over the "seat of the government" and other places purchased with state consent "for the erection of forts, magazines, arsenals, dockyards, and other needful buildings." The 1789 statute implemented each of these constitutional provisions while adding several other offenses not expressly mentioned in the Constitution. ${ }^{319}$

Section 1 repeated the constitutional definition of treason as "levy[ing] war" against the United States or "adher[ing] to their enemies, giving them aid and comfort," and added that the prohibition applied-as seemed implicit in the term itself-only to "persons owing [ ] allegiance to the United States." ${ }^{320}$ It went on to reiterate the constitutional requirement that the offense be proved by "two witnesses to the same overt act" or by "confession in open court." In specifying that the witnesses testify to a single "overt act of the treason" Congress may have lent some support to the argument that the overt act must itself be culpable-a crucial issue that was to divide the Supreme Court a century and a half later. ${ }^{321}$ Finally, in accord with Article III's provision authorizing Congress "to declare the punishment of treason," $\S 1$ prescribed that anyone convicted of that offense should "suffer death"-thus conforming to the constitutional strictures restricting "forfeiture" and "corruption of blood" while reinforcing the

319 Article I, § 8, cl 14 also authorized Congress "[t]o make rules for the government and regulation of the land and naval forces," and Article IV, $\S 3$, cl 2 authorized it to "make all needful rules and regulations respecting the territory or other property belonging to the United States." The First Congress provided for crimes under the former by ratifying the Articles of War adopted under the Confederation, see text accompanying note 231, and under the latter by reaffirming and extending the Northwest Ordinance, which envisioned executive adoption of "such laws of the original States . . . as may be necessary" pending convocation of a territorial legislature. See 1 Stat 50-52 (Aug 7, 1789) (confirming and reprinting the 1787 Ordinance); 1 Stat 123 (May 26, 1790) (extending most of its provisions to the territory south of the Ohio). Section 16 of the 1789 statute, 1 Stat at 116, which made it a federal crime to steal or embezzle military arms or supplies, seemed not only necessary and proper to Congress's power to "raise and support armies"; it too could easily be defended as an exercise of Article IV's authority to "make ... needful rules and regulations respecting the ... property belonging to the United States."

3201 Stat at 112. Like Article III itself, the statute was ambiguous as to whether phrases respecting adherence and aid to enemies established one offense or two. See Cramer $v$ United States, 325 US 1, 29 (1945).

${ }^{321}$ Cramer, 325 US at 29-35 (act must be culpable); id at 61 (Douglas dissenting) (act that "may appear ... innocent or indifferent," standing alone, "is insufficient"). See The Second Century at 294-99.

${ }^{322}$ In emphasizing that no conviction for any offense under the statute should "work 
implication that the ban on cruel and unusual punishment in the proposed Eighth Amendment did not automatically preclude the deprivation of "life" expressly contemplated by the Fifth Amendment.

More striking was the following section of the statute, which defined misprision of treason as concealment or failure to disclose the commission of treason by others and provided a punishment of imprisonment and fine. ${ }^{323}$ The Constitution said nothing of this offense. Congress may have thought the power to punish misprision implicit in its authority to "declare the punishment of treason" itself; it may have concluded that the provisions setting up the Government implied authority to protect it from destruction. In any event the legislators must have interpreted the narrow definition of treason in Article III not to preclude it from creating lesser related offenses that might otherwise fall within federal purview-although nothing in the misprision provision suggested that Congress had yet considered the possible impact of the Treason Clause on efforts to punish seditious expression.

As authorized by the exclusive-legislation provision of Article I, § 8, various sections of the statute proscribed such offenses as murder, manslaughter, mayhem, and larceny in any place under the sole and exclusive jurisdiction of the United States. ${ }^{324}$ The most controversial provision of the entire statute was $\S 4$, which authorized the court, after imposing a death sentence for murder, to order "that the body of [the] offender ... be delivered to a surgeon for dissection. ${ }^{3325}$ In the House it was argued that dissection "was wounding the feelings of the living, and could do no good." Stone added that it "ma[de] punishment wear the ap-

corruption of blood, or any forfeiture of estate," $\S 24$ went beyond Article III, $\S 3$, which forbade "corruption of blood, or forfeiture, except during the life of the person attainted" and only in the case of treason.

${ }^{323} 1$ Stat at 112 \& 2.

${ }^{324} 1$ Stat at $113,115-16 \S \S 3,7,13,16,17$. Section 6 provided punishment for misprision of these offenses. Id at 113. No provision was made at this time for punishing lesser offenses in federal enclaves; Congress's later assimilation of state laws for this purpose would raise interesting constitutional questions. See the Assimilative Crimes Act of 1948, 62 Stat 686, ch 645, § 13 (1948), codified as amended at 18 USC \& 13 (1988); United States $v$ Sharpnack, 355 US 286, 293-94 (1958).

${ }^{325} 1$ Stat at 113 . For the grisly background of this provision, see Steven Robert Wilf, Anatomy and Punishment in Late Eighteenth-Century New York, $22 \mathrm{~J}$ Soc Hist 507 (1989). Section 5's further provision of penalties against anyone interfering with such an order was necessary and proper to its effectuation on the theory evinced elsewhere in the statute, if the dissection itself was constitutional.

${ }^{326} 2$ Annals at 1572. 
pearance of cruelty, ${ }^{n 27}$ conjuring up visions of the corresponding amendment that Congress had just proposed.

Dissection was defended both on the ground that it "increased the dread of punishment" and on the ground that it would promote the progress of science. ${ }^{328}$ The first argument appeared to confirm Stone's objection, the second to revive the controversy over whether Congress had general authority to promote the advancement of knowledge. ${ }^{329}$ So long as the offense occurred within an enclave subject to exclusive federal jurisdiction, however, there could be no doubt that the subject fell within congressional authority. ${ }^{330}$

Sections 8 through 13 implemented Congress's express authority to "define and punish piracies and felonies committed on the high seas." ${ }^{331}$ The statute seemed to take an exceedingly broad view of what constituted piracy, for it branded as a "pirate" both the mariner who "r[a]n away with" a ship or $\$ 50$ worth of cargo and the ordinary mutineer who should "make a revolt in the ship." ${ }^{332}$ From the constitutional standpoint no harm was done, since all of the acts punished were felonious and Congress's power extended to all felonies on the high seas. ${ }^{333}$

More significantly, the prohibitions were not strictly limited to the high seas but extended as well to crimes committed "in any river, haven, basin or bay, out of the jurisdiction of any par-

327 Id.

323 Id.

329 See text accompanying notes $\mathbf{1 3 0 - 3 5}$

300 The dissection provision also applied to murder committed on the high seas, for which the statute also provided the death penalty. Congress's power to enact a general code of laws (as contrasted with the punishment of felonies alone) for that realm was not so plain, though the Necessary and Proper Clause in conjunction with the Commerce Clause or with the Admiralty Clause of Article III might have provided a basis of authority. See text accompanying notes 87-93 (discussing seamen).

${ }^{331} 1$ Stat at 113-15, §§ 8-13; US Const, Art I, \& 8, cl 10.

3321 Stat at $114 \S 8$. In the former case punishment was imposed only if the act was done "piratically" or "feloniously." Whether in this context "piratically" meant anything more than with felonious intent seems doubtful.

${ }^{333}$ Section 8 also forbade murder, robbery, and "any other offence which if committed within the body of a county, would by the laws of the United States be punishable with death." 1 Stat at 113-14 \& 8. The reference to "laws of the United States" seemed to suggest federal law, but as so construed it was arguably unnecessary; most federal criminal provisions were not restricted in their geographical application. To conclude that Congress meant to incorporate the laws of the several states as they might stand at the time of the offense would present an interesting constitutional question. See note 324 . Possibly Congress intended only to make applicable all criminal laws applying to areas of exclusive federal jurisdiction. See also 1 Stat at 115-16 $\S 12,13,16$ (outlawing manslaughter, mayhem, and larceny on the high seas). 
ticular state. ${ }^{334}$ Whether Congress thought authority over such places included within the ostensibly narrower term "high seas," necessary and proper to the regulation of commerce or to the exercise of admiralty jurisdiction, or implicit in a central government responsible for external affairs is not clear. One can easily imagine the contrary argument that each state was responsible for the actions of its citizens in places neither within any territorial jurisdiction nor upon the high seas. Easier perhaps to sustain were the provisions of $\S \S 10$ and 11 punishing anyone on land as well as on sea who aided or abetted the commission of a crime at sea; $; 35$ punishment of earthbound accessories could without much effort be found necessary and proper to prevention of the offense itself.

Section 14, as authorized by Article I, § 8, provided the punishment for counterfeiting "any certificate, indent, or other public security of the United States."${ }^{\text {"336 }}$ It was fair enough to construe the constitutional grant to embrace alteration and forgery of securities, assistance to counterfeiters, and perhaps even knowing use of counterfeit instruments, each of which the statute proscribed. ${ }^{337}$ What created a small stir in the House was that the punishment provided for all these offenses was death, which some members plausibly suggested might be excessive even in 1789. ${ }^{338}$ Sedgwick was heard to say "that he thought the degrees of punishment ought to be proportioned to the malignity of the offence, ${ }^{, 339}$ and one day the Supreme Court would interpret the Eighth Amendment to require just that. ${ }^{340}$ For the moment, however, no one tied the argument for proportional penalties to anything in the Constitution.

Sections 25 through 28 of the statute forbade violence against foreign diplomats and judicial seizure of their person or

3341 Stat at $113 \S 8$.

2351 Stat at 114.

${ }^{336} 1$ Stat at 115. Nothing was said of counterfeiting coins, possibly because at the time-despite yet another exemplary report from the Secretary of the Treasury, 7 Hamilton Papers at 570 (Jan 28, 1791) (cited in note 48)-the mint had not yet been established. See 1 Stat 246 (Apr 2, 1792).

${ }^{337}$ For later views on the breadth of this authority see United States $v$ Marigold, 50 US 560, 566-67 (1850); The First Hundred Years at $234 \mathrm{n} 270$.

338 Annals at 1573-74.

339 Id at 1573. Consider W.S. Gilbert, The Mikado, Act II, 11 337-44, in Ian Bradley, ed, The Annotated Gilbert and Sullivan at 325 (Penguin, 1982). Sedgwick was eventually reconciled to the terms of the provision. 2 Annals at 1573.

${ }_{340}$ Weems $v$ United States, 217 US 349 (1910). See also Coker $v$ Georgia, 433 US 584 (1977); Enmund v Florida, 458 US 782 (1982); Solem v Helm, 463 US 277 (1983); Harmelin v Michigan, 501 US 957 (1991); The Second Century at 57, 550 n 315. 
goods. ${ }^{341}$ No reliance on inherent or implied powers over foreign affairs was necessary to justify these provisions. The statute plausibly described each of these offenses as a violation of "the law of nations," which Article I, § 8 expressly empowered Congress-within reason, one assumes-to define as well as punish.

This is the point at which explicit constitutional authority for the creation of federal crimes runs out. But the statute went on to define additional crimes: theft or falsification of court records, perjury, bribery of federal judges, interference with judicial process, and liberation of federal prisoners. ${ }^{342}$ All these provisions were plainly necessary and proper to the operation of the federal courts; Marshall was to cite the perjury section as a precedent for the existence of implicit powers in M'Culloch $v$ Maryland. ${ }^{343}$ Nor was this the first time that Congress had established criminal penalties for acts outside the specific grants of authority to define federal crimes. Penalties previously prescribed for unloading ships in the dark or without a license ${ }^{344}$ were obviously ancillary to collection of customs duties; penalties against census takers who failed to report their findings ${ }^{345}$ were plainly appropriate to enumeration of the people. Clearly the First Congress did not view the list of topics of federal criminal law as implicitly negating authority to create other offenses when that was necessary and proper to the exercise of some other explicit federal power. ${ }^{346}$

\section{States}

When the First Congress met in 1789 there were eleven states in the Union. When it adjourned two years later it had made provision for fifteen.

311 1 Stat at 117-18.

3421 Stat $115-17 \& \S 15,18,21-23$. The penalties prescribed included whipping for tampering with court records or embezzling government property, id at 115-16 §§15, 16, and lifetime disqualification from federal office for a judge who accepted a bribe. Id at 117, $\$ 21$. These provisions suggest not only that Congress viewed neither of these punishments as cruel and unusual, but also that they did not understand impeachment to be the sole avenue for future disqualification of current officeholders.

343 17 US 316, 417 (1819).

34 1 Stat 29,39 \& 12 (July 31,1789 ).

sus 1 Stat 101, 102 §§ 2-3 (Mar 1, 1790).

366 Similarly necessary to operation of the courts were the procedural provisions of $\S$ 29 , which (pending ratification of the proposed Bill of Rights) guaranteed the criminal defendant rights to a copy of the indictment, to employ counsel, and to call and subpoena witnesses. The power to enact statutes of limitation for various offenses, $\S 32$, seems implicit in the authority to define the offense itself. See 1 Stat at 118-19. 
The Articles of Confederation had described the Union they established as "perpetual" and subject to alteration only with the approval of "the legislatures of every State." radical Rhode Island was unlikely to endorse the new Constitution, the Framers had ignored this requirement, providing that the new Constitution would take effect on ratification by nine of the thirteen original states. ${ }^{348}$ They were prescient if revolutionary in doing so, for not only Rhode Island but North Carolina as well initially declined to ratify the Convention's proposal. ${ }^{349}$

The new Congress proceeded to employ both carrot and stick to induce the two delinquents to join the new Union. North Carolina and Rhode Island shipowners were temporarily accorded "all the privileges and advantages to which ships and vessels owned by citizens of the United States, are by law entitled"350 - that is, lower tonnage and tariff duties and a federal license. ${ }^{351}$ At the same time, however, a variety of goods produced in North Carolina or Rhode Island were subjected to customs duties when "brought into the United States"-just like goods "imported from any foreign state, kingdom or country."352

It did not take long for North Carolina to get the message. A second convention, dominated by Federalists, reversed the initial negative vote, and a new legislature appointed two Federalist Senators. ${ }^{353}$ On February 8, 1790, Congress extended the tariff,

347 Stat 4, 8-9, Art 13.

34 US Const, Art VII. The Framers also provided for ratification by popular conventions instead of legislatures in order both to increase the chances of approval and to avoid any implication that the new Constitution, like the old, was a mere compact between states that could be dissolved if breached by one of its parties. Farrand, 2 Convention Records at 88-94 (cited in note 35). Legal justifications for these departures from the Articles ranged from their dissolution by breach to ultimate popular sovereignty. Id at 469 (James Wilson) ("We must . . . in this case go to the original powers of Society, The House on fire must be extinguished, without a scrupulous regard to ordinary rights.").

349 See Richard B. Morris, The Forging of the Union, 1781-1789 315-16 (Harper \& Row, 1987). Rhode Island had not even sent delegates to the Convention. Farrand, 1 Convention Records at 1-2.

3501 Stat 69 \& 2 (Sept 16, 1789).

351 See text accompanying notes 69-75.

352 1 Stat at 70 \& 3. See 1 Annals at 162-63 (Rep Ames) (urging a stiff tariff on barley and lime because they were "imported in considerable quantities from a neighboring State that had not yet adopted the constitution; and, perhaps ... our political situation is such as to make some regulation on this head necessary").

${ }^{353}$ See Morris, Forging of the Union at 315-16 (cited in note 349). Washington reported North Carolina's ratification to the Senate on Jan 11, 1790. See 1 Annals at 971. The proposal of the Bill of Rights played a significant role in this decision; North Carolina had made constitutional amendments a condition of ratification. See Helen E. Veit, Kenneth R. Bowling, and Charlene Bangs Bickford, eds, Creating the Bill of Rights xi, xvi, 245, 269 (Johns Hopkins, 1991). 
tonnage, and licensing laws to North Carolina and declared that the sanctions imposed against that state the preceding year had expired on its accession to the Union. ${ }^{354}$

Rhode Island was given two brief months to see the light as its semi-foreign status was extended until April $1^{355}$ Implicit was the threat that if Rhode Island did not ratify it would be treated as foreign, and thus subject both to import duties on all its products and to discriminatory treatment of its shipping. But as April passed without favorable action, the Senate passed a bill that would have gone much further by banning all commercial intercourse between Rhode Island and the United States and requiring the payment of $\$ 27,000$ - that state's purported share of the cost of discharging federal obligations entered into before the new Constitution took effect. ${ }^{356}$

House action on this bill was mooted a few days later when Rhode Island capitulated and swallowed the Constitution. ${ }^{357}$ The bill itself nevertheless bristled with troublesome constitutional questions. On its face the ban on intercourse seemed to reflect a conviction that the power to regulate commerce included the power to prohibit it. ${ }^{358}$ Yet the preamble to the bill, in declaring the measure "necessary to the security of the Revenue, [and] other essential interests of the United States,"359 appeared to argue that it was necessary and proper to the collection of taxes, ${ }^{360}$ if not also to national defense. ${ }^{361}$ The demand for money appears to have been based on the theory that Rhode Island shared responsibility for debts contracted under the Confederation, to which it was a party. The Articles had required each state to contribute its share toward financing legitimate expendi-

354 1 Stat 99, 99-100 §§ 1-6. The Judiciary Act was extended to North Carolina on June 4. 1 Stat 126.

35s 1 Stat at 100-01 $\S 7$.

356 See 1 Annals at 1003, 1009, 1012. The bill itself, together with antecedent resolutions and committee reports, appears in 6 Doc Hist at 1810-14.

${ }^{357}$ See 1 Annals at 1018, 2 Annals at 1684-85. See also 1 Stat 126, (June 14, 1790); 1 Stat 128 (June 23,1790 ) (promptly extending various federal statutes to Rhode Island).

${ }^{358}$ Compare note 41.

${ }^{359}$ See 6 Doc Hist at 1813.

360 "I should be glad to know if any gentleman contemplates the State of Rhode Island dissevered from the Union; a maritime State, situated in the most convenient manner for the purpose of smuggling, and defrauding our revenue." 1 Annals at 440 (Rep Ames). Representative Page argued that the bill would encourage rather than prevent smuggling, since it would shut off the most natural outlet for Rhode Island goods. "It would be thought madness" in Europe, he added, "to interdict all commercial intercourse of neighboring States, merely with a view to prevent smuggling." 2 Annals at 1673.

${ }^{362}$ "The bill had been assigned to Various Motives[:] self defense[,] self preservation, self interest[, etc.]" Maclay, Diary, in 9 Doc Hist at 271. 
tures, but the Articles were no longer in force; the prescribed method of finance under the new Constitution was taxation of individuals, not contributions by states. ${ }^{362}$ Very likely the Senate thought Congress had implicit authority to collect sums owed to its predecessor, although Article VI, which specifically addressed the status of prior obligations, explicitly preserved only claims against the United States-by which it seemed to mean the federal government, not the individual states. ${ }^{363}$

Supporters of the bill "did not deny," wrote Maclay, that its true purpose was to coerce Rhode Island into the Union; ${ }^{364}$ "it was meant to be Used the same Way That a Robber does a dagger or a Highwayman a pistol[:] to obtain the end desired by putting the party in fear. ${ }^{\prime 365}$ This line of reasoning may seem to suggest the further possibility that both the ban on intercourse and the demand for indemnity might have been necessary and proper to the (involuntary) admission of new states under Article IV. ${ }^{366}$ Yet Congress at no time considered Rhode Island a "new State" subject to the requirements of Article IV. As in the case of North Carolina, Congress passed no act to admit Rhode Island to the Union; once those states ratified the Constitution, Congress simply extended federal laws to include them. ${ }^{367}$ The fact that such legislation was thought necessary seems to refute the alternative hypothesis that Congress thought ratification by nine states made the Constitution binding on all thirteen; as Maclay insisted, "[t]hey admitted all hands That Rhode Island was independent.."368 Thus Congress appears to have viewed Article VII

${ }^{362}$ Compare Articles of Confederation, Art 8, with US Const, Art I, § 8, cl 1.

${ }_{363}$ See the discussion of Congress's authority to assume state obligations in the text accompanying notes 179-92. An alternative explanation might be that the Senate thought the implicit federal power over external affairs empowered it simply to demand tribute from independent states, on the pattern of the Barbary pirates. See text accompanying notes 268-75.

9 Doc Hist at 264. See also 2 Annals at 1672-74 (Rep Page).

${ }^{365} 9$ Doc Hist at 271.

${ }^{366}$ See US Const, Art IV, § 3: "New States may be admitted by the Congress into this Union ...."

${ }^{367}$ See notes 354 and 357.

${ }^{368} 9$ Doc Hist at 264. Congress had acknowledged that neither Rhode Island nor North Carolina was a part of the Union in 1789 by providing for the payment of customs duties when certain goods from those states were "brought into the United States." See note 352. Indeed, if North Carolina and Rhode Island were part of the United States in 1789 , the act for collection of customs duties was arguably unconstitutional, for it named no port in either state as a port of entry for goods imported from other countries; Article I, $\S 9$, cl 5 forbids Congress in any commercial or revenue measure to give any "preference ... to the ports of one State over those of another." See 1 Stat at 69-70 § 3. The Articles of Confederation, of course, had protected Rhode Island from being forced to 
as giving all thirteen members of the Confederation, like Canada under the Articles, ${ }^{369}$ a right to join the Union unilaterally at any time. On this hypothesis, coercion seemed to cast a cloud on the validity of Rhode Island's ultimate act of accession; for Article VII appeared to contemplate that each state would make the decision whether or not to ratify as a matter of its own free will. ${ }^{370}$

In contrast, when the President in December 1790 transmitted to Congress a petition from a popularly elected convention seeking the admission of Kentucky as a state, ${ }^{371}$ there was no doubt that Article IV provided the appropriate route to statehood. Since Kentucky was a part of Virginia, it could not be admitted without Virginia's consent, but Virginia had benevolently agreed. $^{372}$ Interestingly, the petition requested congressional approval no later than November 1791, to allow time for the new state to adopt a constitution before June 1, 1792-the date on which Kentucky desired to become a member of the Union. ${ }^{373}$ One might have expected Congress to insist on seeing the state constitution before giving its approval, especially in light of the obligation of the United States under the same Article to "guarantee to every State in this Union a Republican form of Government,"374 but it did not; the resulting statute unconditionally declared that Kentucky "shall be received and admitted into this Union" on the appointed date, "as a new and entire member of the United States of America." ${ }^{375}$

accept any revised plan of union without its consent. See text accompanying note 347.

${ }^{360}$ Articles of Confederation, Art 11.

${ }_{370}$ See 2 Annals at 1672 (Rep Page) ("[I]t becomes this House to take care therefore that their sister State, now about to consider of the propriety of adopting the Constitution, shall be as free to judge for herself as was any other State in the Union."). Consider in this regard the later controversy over ratification of the Fourteenth Amendment by states that were required to ratify in order to regain their representation in Congress. 14 Stat 428, 429 \$ 5 (Mar 2, 1867); The First Hundred Years at 296-99.

371 See 2 Annals at 1773-75 (Dec 9, 1790).

${ }^{372}$ See 2 Annals at 1774; US Const, Art IV, § 3, cl 1: "but no new State shall be formed or erected within the jurisdiction of any other State ... without the consent of the legislatures of the States concerned, as well as of the Congress."

${ }^{373}$ See 2 Annals at 1774-75.

374 US Const, Art IV, $\S 4$.

3751 Stat 189, \& 2 (Feb 4, 1791). An earlier draft of the bill would have made admission conditional on Kentucky's ratification of the federal Constitution, but this proviso was dropped in the Senate-whether on the expectation that Kentucky would ratify of its own accord or on the assumption that Article IV did not require ratification is not clear. See 5 Doc Hist at 1219. Congress did make some effort to assure that Kentucky would make an acceptable member of the Union, for the Senate Committee repeated the petitioners' assertion that its people were "devoted to the American Union" and added that they were "sufficiently numerous for all the purposes of an independent State." 2 Annals at 1784-85; 5 Doc Hist at 1218. The propriety of some such inquiry is surely implicit in the discretion 
But Kentucky was destined to become the fifteenth state, not the fourteenth. For on February 9, five days after the Kentucky bill became law, President Washington transmitted to Congress "authentic documents" received from "the Governor of Vermont . . . expressing the consent of the Legislatures of New York and of the Territory of Vermont, that the said Territory shall be admitted to be a distinct member of our Union." 376 Nine days later the President signed legislation admitting Vermont to the Union as of March 4, 1791-nearly fifteen months before the date set for the admission of Kentucky. ${ }^{377}$

Washington's message had called Vermont a "Territory"; the statute described it, at the time of its petition, as a "state." Vermont lay within the boundaries of the United States as defined by the Treaty of Paris, but it was not one of the "States" whose sovereignty and independence Great Britain in that treaty had confirmed. ${ }^{378}$ As indicated by the President's message, Vermont had already set up its own government; New York's consent to the application reflected its claim that Vermont was a part of New York. $^{379}$ In admitting Kentucky, Congress expressly acknowledged Virginia's consent; the Vermont statute said nothing

afforded by Article IV, § 3's provision that new states "may be admitted" by Congress. See also 19 Jefferson Papers at 369-70 (cited in note 12) (editorial note), making comparisons between Kentucky and Vermont on the question of devotion to the Union, to the decided detriment of the latter.

3762 Annals at 1798.

3771 Stat 191 (Feb 18, 1791).

${ }_{378}$ Definitive Treaty of Peace Between the United States of America and his Britannic Majesty, Art I, II, 8 Stat 80, 81 (Sept 3, 1783).

${ }_{379}$ New York's initial charter in 1664 embraced "all the land from the West side of Connecticut to the East side of Delaware Bay"; a confirmatory charter in 1674 spoke of lands west of "Connecticut River," which plainly included Vermont. Chilton Williamson, Vermont in Quandary: 1763-1825 9-10 (Vermont Historical Society, 1949). Undaunted by a 1764 Privy Council decision fixing the Connecticut River as the boundary between New York and New Hampshire (which, like Massachusetts, also had claims on Vermont territory), Vermont had declared its independence from everybody in 1777 . 4 Acts of the Privy Council of England: Colonial Series 673 (July 20, 1764); Matt Bushell Jones, Vermont in the Making: 1750-1777 x, 376 (Harvard, 1939). Vermont's repeated applications for admission to the Confederation were unsuccessful, in part because of its own refusal to permit Congress to settle its continuing disputes with New Hampshire and New York and in part because of opposition from New York and from Southern states not wishing to be further outnumbered. William Doyle, The Vermont Political Tradition: And Those Who Helped Make It 49-51 (Northlight Studio, rev ed 1987). Meanwhile Vermont adopted a liberal constitution, coined its own money, set up its own post offices, negotiated with foreign powers, and established a policy of free trade with Quebec. Id at 52. Alarmed at the economic implications of these independent actions, Alexander Hamilton led the campaign for Vermont's admission to the Union, and New York dropped its objections when Vermont agreed to compensate the holders of New York land grants within its borders. See Williamson, Vermont in Quandary at 175-77. 
about New York. Thus Congress seems to have thought New York's approval unnecessary and to have implicitly rejected its claim; but since New York had consented, the validity of its claim was no longer of constitutional significance.

As initially drafted, the bill provided that, until House seats were apportioned according to the census, Vermont should be entitled to two Representatives. ${ }^{380}$ Omitted in the Senate, ${ }^{381}$ this section became part of a separate statute making an identical provision for Kentucky as well. ${ }^{382}$ This allotment was reasonably proportioned to each state's estimated population, as Article I, $\S 2$ required; ${ }^{383}$ authority to make an interim apportionment seems implicit in the power to admit new states. ${ }^{384}$

On March 2, 1791, two days before Vermont was to become a member of the Union, the President signed a law extending federal laws to the new state, "from and after the third day of March next."385 On March 3 the First Congress expired; ${ }^{386}$ the

seo See 6 Doc Hist at 2010.

sei See 2 Annals at 1799 (Feb 11, 1791).

3821 Stat 191 (Feb 25, 1791).

${ }^{383}$ The 1790 census determined the populations of Vermont, Kentucky, and the United States to be $85,539,73,677$, and $3,893,635$ persons respectively. Return of the Whole Number of Persons Within the Several Districts of the United States 3, 10, 47 (Arno Press, 1976) (first published 1802). After adjusting the slave population pursuant to Art I, $\S 2$, this meant that Vermont comprised $2.4 \%$ and Kentucky $1.9 \%$ of the U.S. population. Thus by giving each state two of sixty-nine representatives (2.9\% of the total representation), the First Congress left Vermont and Kentucky slightly overrepresented in the House.

384 No such statutory provision had been necessary in the case of Rhode Island or North Carolina, to which Article I, § 2 itself allotted one and five Representatives, respectively.

3es 1 Stat 197.

386 See the report of a joint committee, 1 Annals at 1010, concluding that the initial presidential and legislative terms had begun March 4, 1789-the date appointed by the old Congress for the first meeting of the new-and that consequently Senators of the first class (those whose terms were to last only two years) and Representatives would not be entitled by virtue of their initial election "to seats in the next Congress, which will be assembled after the 3d day of March, 1791." As Representative Smith pointed out privately, this meant that North Carolina's representatives, who had not been elected until 1790, would sit for only one year. See Letter of William L. Smith to Edward Rutledge, May 24, 1790, in Rogers, 69 Carolina Historical Magazine at 116 (cited in note 106).

In the House it was objected that Congress had no business making such a determination, since "every successive House must be the sole judge of the qualification of its members." 2 Annals at 1637. Compare US Const, Art I, $\S 5$. Others responded that the Constitution plainly contemplated dissolution of one Congress before election of another, and both Houses approved the report. See 1 Annals at 1011; 2 Annals at 1637-38. What the last speaker meant to say was that dissolution of one Congress must precede installation of another, and even that did not preclude finding that members could sit until their successors had qualified. The Constitution said only that members should be "chosen every second Year," Art $I, \S 2$; to the extent this provision was ambiguous, Congress 
next day Washington called a special session of the Senate to pass upon his nominations to federal offices in Vermont. "The act for the admission of the State of Vermont into this Union, having fixed on this as the day of its admission," the President explained, "it was thought that this would also be the first day on which any officer of the Union might legally perform any act of authority relating to that State. ${ }^{388}$ If this left uncertain why Washington had been willing to sign the bill extending the laws to Vermont two days earlier, it showed once again the extreme care he took at all times to conform his conduct to the Constitution.

But the First Congress was not content to incorporate two former states and admit two new ones; it also took time to regulate interstate relations. Article $I V, \S 1$ provided that "[f]ull faith and credit sh[ould] be given in each State to the public acts, records, and judicial proceedings of every other State" and empowered Congress "by general laws" to "prescribe the manner in which such acts, records, and proceedings shall be proved, and the effect thereof." Acting under this authority, Congress in May 1790 enacted a statute providing that "acts of the [state] legislatures" should be authenticated by affixing the state seal; that state judicial records and proceedings should be "proved or admitted in any other court within the United States" by attestation of the clerk, seal of the court, and certificate of the judge; and that "the said records and judicial proceedings" should be given "such faith and credit ... in every court within the United States, as they have by law or usage in the courts of the state from whence the said records are or shall be taken."389

This brief statute had a number of implications for constitutional interpretation. First of all, Congress seems to have understood Article IV's reference to "public acts" to embrace all "acts of the [state] legislatures"-despite the fact that the inclusion of the term had been defended in the Convention on the narrow ground that it was necessary to provide for what we would now call

arguably had implicit authority to flesh it out in order to exercise the responsibilities given it by the Constitution.

${ }^{387}$ See 2 Annals at 1826. Article II, $\$ 3$ authorizes the President, "on extraordinary occasions, [to] convene both Houses, or either of them" (emphasis added).

383 Annals at 1827. Until the day of Vermont's admission, Jefferson had advised the President, "it will not be a separate and integral member of the [United States] and it is only to integral members of the union that his right of nomination is given by the Constitution." 19 Jefferson Papers at 376, 377 (cited in note 12).

389 I Stat 122 (May 26, 1790). 
"private" insolvency legislation, the impact of which was similar to that of a judicial decision. ${ }^{390}$ On the other hand, notwithstanding the apparently all-embracing constitutional reference to state "records," the statute seemed to provide for the manner of proving only judicial records-whether as a matter of policy or of constitutional interpretation it is impossible to say.

In providing that properly authenticated records and proceedings should be given the same faith and credit everywhere that they had at home, the last sentence of the act raised a number of interesting issues. First, though it would later be argued that the term "faith and credit" referred only to the authenticity of foreign records, this sentence appeared (as the Supreme Court was to hold) to be an exercise of Congress's authority to prescribe the "effect" of one state's judgments in another, and to make those judgments as binding as they were in the court that had rendered them. ${ }^{391}$ Furthermore, though Congress made no attempt to go beyond the language of Article IV by prescribing the credit to be given to federal judgments, it did require federal courts to respect the judgments of the states ${ }^{392}$-a provision that could easily be explained as necessary and proper to the establishment and operation of federal courts under Article III. Finally, while prescribing the manner of proving state statutes, the act said nothing about the effect to be given them. Perhaps it was wise for Congress not to attempt to resolve all the problems of interstate choice of law while it was still wrestling with the difficulties of setting up the Government; it seems less defensible that two centuries later it still had not devoted serious attention to the problem. ${ }^{393}$

\section{E. Territories}

The British claims relinquished by the Treaty of Paris reached as far north and west as the Lake of the Woods and the

390 See Farrand, 2 Convention Records at 447-48 (cited in note 35); The Second Century at $70 \mathrm{n} 115$.

${ }^{391}$ See Mills $v$ Duryee, 11 US 481 (1813); Hampton v M'Connel, 16 US 234 (1818); The

First Hundred Years at 193 n 261. For the contrary view see Mills, 11 US at 485-87 (Johnson dissenting).

3921 Stat at 122.

${ }^{393}$ The present statute, enacted in 1948, says unhelpfully that public acts as well as records and proceedings shall be given the same faith and credit everywhere as they have at home; it makes no effort to say when one state must defer to the laws of another. 28 USC $\$ 1738$ (1988). See Brainerd Currie, Full Faith and Credit, Chiefly to Judgments: A Role for Congress, $1964 \mathrm{~S} \mathrm{Ct}$ Rev 89, 90, 121. 
Mississippi River. ${ }^{394}$ Maryland had held up ratification of the Articles of Confederation until other states surrendered to Congress their claims to territory north and west of the Ohio River, ${ }^{395}$ and the Confederation Congress had adopted the celebrated Northwest Ordinance to govern the Northwest Territory in $1787 .^{396}$

The most arresting feature of this Ordinance was the audacity of the Continental Congress in enacting it at all. One searches the Articles in vain to find even the slimmest reed to support the power of Congress to adopt such a measure. Yet under the Ordinance a federal territory was set up and governed with general acquiescence. One lesson of this incident may be that necessity is at least as important a determinant of de facto authority as is any written constitution.

But the Ordinance was as remarkable for what it said as for what it was. Of perhaps greatest lasting significance was the provision in Article $\mathrm{V}$ for dividing the Territory into three to five states, to be admitted to the Union as soon as they acquired 60,000 free inhabitants. ${ }^{397}$ We were not to retain colonies in our own country indefinitely. Moreover, the new states were to be admitted "on an equal footing" with the old; there would be no second-class members of the Union. Vital as it was to harmonious relations, the equal footing doctrine was later found implicit in the Philadelphia Constitution; ${ }^{398}$ the Ordinance was its source and its inspiration. ${ }^{399}$

Pending statehood, the Ordinance provided for congressional appointment of a Governor and three judges, who jointly were to adopt "such laws of the original states criminal and civil as may be necessary and best suited to the circumstances of the district," subject to disapproval by Congress. ${ }^{400}$ As soon as the Territory had 5,000 free male inhabitants, a general assembly was to be elected; but its authority to enact laws "for the good government of the district" would be shared with a legislative council selected by Congress from names the assembly submitted, subject to an

3948 Stat at $81-82$, Art II.

395 See Jensen, The New Nation at 25-26 (cited in note 15).

39632 Journals at 334 (July 12, 1787). The First Congress readopted the ordinance on August 7, 1789. See 1 Stat 51-53; text accompanying note 422.

397 Journals at 342.

398 Coyle v Smith, 221 US 559, 575-76 (1911); The Second Century at $101 \mathrm{n} 71$.

399 The Ordinance, wrote Professor Morris, was thus both "an unprecedented anticolonial measure and a centerpiece of American federalism." Morris, Forging of the Union at 231 (cited in note 349).

${ }^{400} 32$ Journals at 336. 
absolute veto by the Governor, who in turn was himself removable by Congress. ${ }^{401} \mathrm{All}$ of this would serve as a precedent under the new Constitution for the delegation of lawmaking authority to local bodies subject to ultimate congressional control, and for federal adoption of state laws to boot. These provisions also established that, despite the Revolution, taxation without representation was not wholly foreign to our system of government. Jefferson's 1784 ordinance for the government of the Territory, which the 1787 enactment superseded, had been considerably more republican. ${ }^{402}$

In addition to these institutional provisions, the Ordinance contained five articles constituting nothing less than a bill of rights for the inhabitants of the Territory. Copied in substantial part from the English Bill of Rights of 1689, with some imaginative additions, these articles were to have a strong influence on the Philadelphia Convention and the amendments proposed by the First Congress. No one "demeaning himself in a peaceable and orderly manner" was to be "molested on account of his mode of worship or religious sentiments." ${ }^{\prime 03}$ There were guarantees of habeas corpus, jury trial, and "judicial proceedings according to the course of the common law," together with assurances that bail would be allowed in most cases, that fines should be "moderate," and that punishments should not be "cruel or unusual."404 No one was to be deprived of "liberty or property but by the judgment of his peers, or the law of the land"; "full compensation" was required whenever "public exigencies" required the taking of property or services; fugitive slaves were to be returned; "no law ought ever to be made, or have force" that would "interfere with, or affect private contracts or engagements ... previously formed." ${ }^{\prime 05}$ Most of these provisions found their way, with some modifications, into either the Constitution or its first eight amendments. The changes that befell the various guarantees during the process of incorporation are most intriguing; in most cases we do not know whether the original wording should be taken as a guide to the implicit understanding of the often less

401 Id at 336-39.

402 See Jensen, The New Nation at 353-54 (cited in note 15).

${ }^{403} 32$ Journals at 340 , Art I.

404 Id, Art II. Bail could be denied only "for capital offences, where the proof shall be evident, or the presumption great."

${ }^{406}$ Id at 340, 343, Arts II, VI. The curious use of the verb "ought" in the clause last quoted raises the question whether the contract provision, in contrast to the others in this enumeration, may have been intended as hortatory rather than binding. 
precise terms later employed or as indicating a desire for substantive change.

The Ordinance's provision for proportionate representation of the people in the legislature was picked up at the interstate level by Article I, $\S 2$ of the new Constitution and read into the Equal Protection Clause of the Fourteenth Amendment for intrastate apportionment in Reynolds $v$ Sims. ${ }^{406}$ The ban on taxation of federal land found an echo in $M^{\prime}$ Culloch $v$ Maryland; ${ }^{407}$ the requirement that the government of the new states be "republican" grew into the universal guarantee of the present Article IV. ${ }^{408}$ The proviso that navigation of western waters should be "forever free ... . without any tax, impost or duty" was to reappear in acts and compacts respecting the admission of new states and thereby to form the basis of at least one important Supreme Court decision. ${ }^{409}$ The prohibition of slavery in the Northwest Territory, copied in the Missouri Compromise of 1820, was to provide the focus of controversy in the Dred Scott case in $1857 .^{410}$ Finally, important provisions conspicuously not echoed in the Constitution imposed on the territorial government the positive obligations to encourage "Schools and the means of education" and to enact laws to prevent wrongs against the Indians. ${ }^{411}$

All six Articles attached to the Ordinance, including the promise of prompt admission to the Union, were declared to constitute not a simple statute but a "compact between the Original States and the people and States in the said territory," unalterable without common consent. ${ }^{412}$ Whether this stipulation really bound Congress is doubtful; it was common ground that the one thing the British Parliament could not do was to divest itself of its powers. ${ }^{413}$ But the existence of this clause lent special digni-

\footnotetext{
${ }^{406}$ See id at 340; 377 US 533, 568 (1964); The Second Century at 430-31.

for See 32 Journals at 341, Art IV; 17 US 316 (1819); The First Hundred Years at 160 68.

${ }_{408}$ See 32 Journals at 342, Art V; US Const, Art IV, $\S 4$.

${ }^{409}$ See 32 Journals at 341, Art IV; Pennsylvania $v$ Wheeling \& Belmont Bridge Co., 54 US 518 (1852); The First Hundred Years at 235. 73.

${ }_{410}$ See 32 Journals at 343, Art VI; 60 US 393 (1857); The First Hundred Years at 263-

41132 Journals at 340, Art III. See generally David P. Currie, Positive and Negative Constitutional Rights, 53 U Chi L Rev 864 (1986).

11232 Journals at 339-40.

413 See A.V. Dicey, Introduction to the Study of the Law of the Constitution 64-68 (Macmillan, 9th ed 1939). See also Stone $v$ Mississippi, 101 US 814, 819 (1880) (permitting a state to repudiate a contract authorizing a lottery for a fixed term, despite the Contract Clause of Article I, $\S 8$, because the state had no right to surrender its police power); The First Hundred Years at 380-81.
} 
ty to the articles and-along with the requirement that the constitutions of the new states were to conform to their principles $^{414}$ _added weight to the later contention that the articles remained in force long after various portions of the Territory had been admitted as states. ${ }^{415}$ The compact language also lent some credibility to the argument that, despite its form, the Ordinance was in fact an interstate agreement approved by Congress as authorized by the Articles of Confederation, and that therefore its exhaustive provisions were not after all a precedent for interpreting the grant of authority in Article IV, $\S 3$ of the new Constitution to "make all needful rules and regulations respecting the territory or other property belonging to the United States." 116

In August 1789, the First Congress passed an act whose stated purpose was to "adapt" the Northwest Ordinance "to the present Constitution," in order that it might "continue to have full effect." ${ }^{\prime 17}$ The Ordinance was not reenacted; Congress plainly assumed it was still in force. A few of its provisions for the territorial government, however, were incompatible with the new division between legislative and executive authority. Originally the territorial officers were responsible to Congress; thenceforth they were to be responsible to the President. ${ }^{418}$

In conforming the Ordinance to the Constitution, Congress seems to have been exercising its power under Article IV to make "needful rules and regulations respecting the territory" of the United States. If the Ordinance itself survived, one might think it did so on the theory that in amending it Congress had implicitly confirmed it under the same grant of authority. This interpretation would mean that the power to make "rules and regulations" was, as it appeared to be, a general power to govern the territory. ${ }^{419}$ Thus when opponents of the ban on slavery in the

414 Journals at 342, Art V.

115 See The First Hundred Years at 268-69.

416 See Articles of Confederation, Art VI, § 2. See also Dred Scott, 60 US at 438-40; The First Hundred Years at 263-73.

117 Stat at 50-51.

418 Compare the provisions of the Ordinance, 32 Journals at 335-36, with $\S 1$ of the statute, 1 Stat at 52-53 (providing that the Governor should be appointed by the President with Senate consent, report to the President, and be subject to presidential removal).

419 In arguing for implicit authority to charter a bank, Ames would soon assert that Article IV conferred a general governmental power not limited, as the words might suggest, to "the management and disposal of property." 2 Annals at 1957. Dismissing the relevance of congressional creation of corporations in the Western Territory, Stone agreed: "[T]o answer this case, nothing more was necessary than to read the clause in the Constitution which gives to Congress expressly the power to make all the rules and regulations" 
Missouri Compromise needed a way to distinguish the Northwest Ordinance they hit upon an alternative explanation: The new Congress had never attempted to enact the Ordinance under the limited authority of Article IV; as an "engagement[] entered into, before the adoption of [the] Constitution," it was "as valid against the United States under [the new] Constitution, as under the confederation" by virtue of Article VI. ${ }^{420}$

A few months after amending the Northwest Ordinance, Congress accepted a deed from North Carolina ceding to the United States that state's claim to territory west of the mountains. ${ }^{421}$ Whether Congress found authority to acquire territory included in Article IV's grant of power to make regulations respecting it, implicit in the power to admit new states, or inherent in the existence of the Government was left unsaid, but nobody seemed to question Congress's authority. In accordance with the terms of the cession, Congress promptly extended the Ordinance to the new Territory with one conspicuous exception: "That no regulations made or to be made by Congress, shall tend to emancipate slaves." 422 This time it seemed there could be no doubt about it; the source of governmental authority over the new Territory was not an interstate compact but the Constitution of the United States. ${ }^{423}$ It seems fruitless to debate whether the attempt to prevent Congress from interfering with slavery there expressed the fear that Congress otherwise would have such power or reaffirmed the conviction that it would not; the language was well chosen to give slave owners maximum protection in either event, though once again there was reason to doubt whether Congress could bind itself not to exercise its constitutional powers. ${ }^{424}$

for the Territories. Id at 1985.

120 See Dred Scott, 60 US at $441-46$.

1211 Stat 106 (Apr 2, 1790). This territory had been ceded to the United States once before, organized into the incipient state of Franklin, and reclaimed by North Carolina after conditions there had become chaotic. See Jensen, The New Nation at 332-34 (cited in note 15). It would later be admitted to the Union under the name of Tennessee.

422 See 1 Stat $123 \S 1$ (May 26, 1790) (incorporating the conditions of the North Carolina cession statute, as found at 1 Stat at 108). This provision, we are told; "occasioned some debate" in the House; "an amendment was proposed and debated, but not adopted." 2 Annals at 1528.

${ }^{423}$ Legal ingenuity being without bounds, opponents of a broad interpretation of Article IV resorted in later analogous cases to notions of a limited extraconstitutional authority difficult to reconcile with the theory of a written constitution. See American Insurance Co. $v$ Canter, 26 US 511, 546 (1828) (leaving the question open); Dred Scott, 60 US 393; The First Hundred Years at 119-22, 263-73.

${ }^{424}$ The United States was owner as well as sovereign of most western land, and from 


\section{F. The Seat of Government}

The first session of the First Congress met in New York, as the Confederation Congress had prescribed. ${ }^{425}$ But in 1783 , the Confederation Congress had felt compelled to abandon Philadelphia when Pennsylvania authorities refused to call out the militia to suppress a mob of unruly soldiers. "If any state had the power of legislation over the place where Congress should fix the general government," said Madison in the Virginia ratifying convention, "this would impair the dignity, and hazard the safety, of Congress."

Article I, $\S 8$ of the new Constitution accordingly authorized Congress "[t]o exercise exclusive legislation . . . over such district (not exceeding ten miles square) as may by cession of particular States, and the acceptance of Congress, become the seat of the government of the United States." It was common ground that Congress ought to acquire territory for a national capital under this provision. There was monumental disagreement over where it should be. ${ }^{427}$

At the end of its first session the House voted, over southern objections, to locate the capital "at some convenient place on the banks of the river Susquehannah in the State of Pennsylvania." ${ }^{328}$ The Senate amended the bill to provide for a capital in the vicinity of Germantown, near Philadelphia. ${ }^{429}$ The House

the beginning its policy had been to dispose of its title in order to promote settlement and raise money to pay off the revolutionary debt. See Morris, Forging of the Union at 228-29 (cited in note 349). Debate, the burden of private bills, and a favorable report from Hamilton persuaded the House that Congress ought to set up a land office to dispose of the property under the authority of Article IV; enactment of the law that did so was postponed until the Fourth Congress. See 1 Annals at 646-57, 1104-10; 2 Annals at 1876-80; 1 Stat 464 (May 18, 1796). For land grants made by statute during the First Congress, see 1 Stat 182 (Aug 10, 1790) (Virginia veterans); 1 Stat 221 (Mar 3, 1791) (settlers at Vincennes); 6 Doc Hist at 1563-1607.

12534 Journals at 521-23 (Sept 13, 1788); 1 Annals at 15, 99.

${ }_{225}$ See Jonathan Elliot, ed, 3 The Debates in the Several State Conventions on the Adoption of the Federal Constitution 89 (2d ed 1836). See also Federalist 43 (Madison), in The Federalist Papers at 288-89 (cited in note 36); Story, Commentaries $\$ \S 594-96$ (cited in note 15). The episode is described in Kenneth R. Bowling, New Light on the Philadelphia Mutiny of 1783: Federal-State Confrontation at the Close of the War for Independence, 101 Pa Magazine of Hist \& Biography 419 (1977). See also George Adams Boyd, Elias Boudinot: Patriot and Statesman 123-26 (Princeton, 1952).

427 "[E]normous prestige, financial advantage, and influence on the government hinged on its location." Ralph Ketcham, James Madison, A Biography 271 (MacMillan, 1971). The full story is told in Kenneth R. Bowling, The Creation of Washington, D.C.: The Idea and Location of the American Capital (George Mason, 1991).

${ }^{128}$ See 6 Doc Hist at 1867; 1 Annals at 946 (Sept 22, 1789).

12 See 6 Doc Hist at 1869; 1 Annals at 88, 89-90, 91, 955-62. The text of the Senate 
agreed to this amendment, but only after attaching an unrelated amendment of its own. The Senate voted to postpone further consideration of the bill, and Congress adjourned without taking final action. ${ }^{430}$

Starting all over in accordance with the decision that unfin: ished business did not survive the end of a legislative session, ${ }^{431}$ a Senate committee in June 1790 proposed that the capital "be placed on the Eastern or North Eastern Bank of the Patomack"332 - and there, thanks to the need for Virginia and Maryland support for the assumption of state debts, it was to remain. ${ }^{43}$ The statute empowered a board of commissioners, appointed by the President and subject to his direction, to define a district "not exceeding ten miles square" between two named points on the Potomac, to acquire "land on the eastern side of the said river" within the district, and to "provide suitable buildings" there to house the various organs of government. All offices "attached to the seat of government" were to be moved to the Potomac in December 1800. In the interim the Government would sit in Philadelphia, and state laws would continue to apply in the new district until Congress otherwise provided. The President was authorized "to accept grants of money" to finance the acquisition of land and the construction of buildings, and Congress appropriated "a sufficient sum" to cover "the necessary expense of such removal. ${ }^{\$ 34}$

amendment varies slightly in the sources cited.

${ }_{430}$ See 1 Annals at 962; Bowling, The Creation of Washington, D.C. at 159-60.

431 See 1 Annals at 1084-88, 1092-94, 1110-12, 1115-18. For Maclay's report of parallel Senate deliberations on this issue, see 9 Doc Hist at 185-91. The rule itself had been adopted, over Pennsylvania's objections, in the context of the capital controversy. "Thus Congress established, and retained for half a century, a joint rule in order to kill a specific bill." Bowling, The Creation of Washington, D.C. at 168 (cited in note 427).

${ }^{432} 6$ Doc Hist at 1779.

433 See text accompanying notes 188-91.

4341 Stat 130 (July 16, 1790). The next year Congress altered the outer limits of the District to permit the inclusion of the East Branch (Anacostia River) and Alexandria, while reaffirming that public buildings should be constructed only "on the Maryland side." 1 Stat 214-15 (Mar 3, 1791). Presidential proclamations actually defining the District appear in James D. Richardson, ed, 1 Messages and Papers of the Presidents 100, 102 (Jan 24 and Mar 30, 1791) (US Congress, 1900). For the suggestion that motives of pecuniary profit induced Washington to place the District closer to his own property than the original statute allowed, see McDonald, Hamilton at 202-04 (cited in note 13). In fact the first proclamation carefully refrained from incorporating the contested area within the district until corrective legislation was safely passed. See also Bowling, 1 Capitol Studies at 66 (cited in note 211) (citing the suspicions of two Virginia Representatives that Congress held up passage of this bill to put pressure on the President not to veto the national bank). 
These provisions evince an appropriately broad congressional understanding of the authority to exercise "exclusive legislation" over the seat of government. Congress interpreted this clause to empower it to acquire not only jurisdiction but also title, to construct buildings, and to accept gifts-in short, to do whatever was necessary and proper to the establishment of a permanent seat of government. ${ }^{435}$ In searching for a way to block passage of an earlier bill that would have placed the capital in Pennsylvania, Madison had argued that Congress had no power to fix a temporary capital: Article I, $\S \S 5$ and 7 gave the two Houses of Congress, acting without the President, sole authority to determine where next to meet. ${ }^{436}$ Sherman's answer seems to have convinced the bulk of his colleagues: Congress's power to meet where it pleased was unaffected by the bill, since Congress was not required to meet at the seat of government. ${ }^{437}$ The express authority conferred by Article I, $\S 8$ extended only to territory ceded by the states, which Philadelphia was not; but providing for the interim location of government offices was clearly necessary and proper to the exercise of their various functions.

From the constitutional viewpoint, the most noteworthy feature of the legislation was the breadth of its delegation of authority. Acting through his commissioners, the President was to determine precisely where to locate the District, how large it would be, what land to acquire, and what buildings to erect. When the original bill had provided for a capital somewhere on

435 See the debate in 1 Annals at 909-11 over whether the Constitution contemplated that the states would cede title as well as jurisdiction. The statute reflects the consensus that after cession the Government would have to acquire title to any land it intended to occupy.

${ }^{436}$ Section 5, cl 4 provides: "Neither House ... shall, without the consent of the other, adjourn for more than three days, nor to any other place than that in which the two Houses shall be sitting." Section 7, cl 3 provides: "Every order, resolution, or vote, to which the concurrence of the Senate and House of Representatives may be necessary, (except on a question of adjournment) shall be presented to the President." See 1 Annals at 940-42; Bowling, The Creation of Washington, D.C. at 75-76, 152 (cited in note 427) (noting the Convention's rejection of Madison's proposal to require a statute to alter the place where Congress met).

${ }^{437} 1$ Annals at 942. See also id at 942-43 (Rep Laurance) (pointing out that Madison's argument seemed equally applicable to the fixing of a permanent capital, which the Constitution plainly envisioned). Madison's argument came back to haunt him when others urged Washington to veto the bill on constitutional grounds after the temporary capital had been changed from New York to Philadelphia. At that point both Madison and Jefferson supported the provision's constitutionality, and the President signed the bill. See 17 Jefferson Papers at 163-205 (cited in note 12). Jefferson's opinion relied heavily on the fact that Congress had twice rejected the constitutional objection: "The sense of Congress itself is always respectable authority." Id at 198. 
the Susquehanna, Tucker had objected that Congress itself should fix the location. ${ }^{438}$ As adopted the statute was marginally more precise: the District should be located "between the mouths of the Eastern Branch and Connoghochegue" (roughly the distance between Washington and Hagerstown, Maryland). ${ }^{439}$ Government needs presumably limited the remaining grants of authority. Under the circumstances it might plausibly be said that in doing what the statute authorized, the President was executing the law rather than exercising the power of "exclusive legislation" granted to Congress.

More problematic perhaps were the statutory provisions appropriating whatever sum might be "sufficient" for necessary moving expenses and preserving the applicability of state law until further congressional action. Other appropriations of the First Congress gave the executive considerable discretion as to how to spend appropriated funds, ${ }^{440}$ but it was arguable that Article I, $\S 9$ required Congress at least to prescribe how much money to spend. Finally, the Constitution explicitly deprived the states of authority to legislate for the District; it was not at all clear that Congress had power to give it back. ${ }^{411}$ In short, in establishing the seat of government under Article I, § 8, Congress took a very flexible and pragmatic view of its ability to rely on other governmental organs to flesh out its general goals. ${ }^{442}$

\section{G. The Bill of Rights}

In ratifying the Constitution, several states exhorted Congress to have it amended. ${ }^{43}$ Many of the suggested amend-

4381 Annals at 913.

4391 Stat at 130 \& 1.

440 See text accompanying notes 112-17.

441 Compare note 129 (discussing pilots) and the text accompanying notes 264-67 (discussing Indians). The provision permitting state law to operate was inserted at Madison's request to "prevent the district ... from being deprived for a time of the benefit of the laws," since "the State relinquished the right of legislation from the moment that Congress accepted of the district." 1 Annals at 961 . It was this amendment that had prevented adoption of the bill at the end of the second session. See Bowling, The Creation of Washington, D.C. at 159 (cited in note 427).

442 As was argued in response to the contention that Congress could not constitutionally delegate authority to designate individual post roads under Article I, \& 8, "the principles of conducting the business are established by the House; the mode of carrying those principles into execution is left with the Executive, and this of necessity is done in almost every case whatever." 2 Annals at 1735.

43 See Elliot, 2 Debates at 177-78 (Massachusetts); 545-46 (Pennsylvania); Elliot, 4 Debates at 238-43 (North Carolina) (cited in note 426); 4 Doc Hist at 12-26; Veit, Creating the Bill of Rights at 14-28 (cited in note 353). 
ments were structural changes that would have reversed the Federalist victory in Philadelphia, but others were elements of a Bill of Rights to protect against possible abuses of federal authority. 444

Hamilton had argued that a Bill of Rights was both unnecessary and dangerous. ${ }^{445}$ Some members of the House were loath to interrupt the important business of setting up the Government to consider constitutional amendments, ${ }^{446}$ but Madison insisted: Prompt action would show doubters that Congress did care for liberty and might persuade North Carolina and Rhode Island to join the new Union. ${ }^{447}$

Carefully culling from the voluminous state suggestions those that would protect basic rights without endangering the "structure" and "stamina" of the government, Madison proposed a list of amendments that bore a strong resemblance to those ultimately adopted. ${ }^{448}$ His further proposals to postpone congressional salary increases and to guard against undue restriction of the number of Representatives were accepted by Congress but never ratified-at least not within the next 200 years. ${ }^{449}$ His requests to include a declaration that all govern-

4' See Veit, Creating the Bill of Rights at ix-xi (cited in note 353). Paranoid antifederalists already perceived in the new Constitution a danger of consolidation of authority. See id at 284-85 (Letter of Samuel Adams to Elbridge Gerry, Aug 22, 1789); id at 299 (Letter of Richard Henry Lee and William Grayson to the Speaker of the Virginia House of Delegates, Aug 28, 1789). History, of course, has proved them right.

45 Federalist 84 (Hamilton), in The Federalist Papers (cited in note 36).

46 See, for example, 1 Annals at 441 (Rep Smith). Vining went so far as to suggest that Article V required a two-thirds vote of both Houses even "to take the subject of amendments into consideration." Id at 447. The text did not seem to support him.

47 Id at 449 . Washington had lent significant support by calling attention to the subject of amendments in his inaugural address. See id at 27-29. See also id at 446 (Rep Page) (warning that if Congress did not act the people would call another constitutional convention). Bland, on behalf of Virginia, had already asked Congress to call such a convention, but dropped his request when Madison (with Tucker contradicente) noted that Article $\mathrm{V}$ empowered Congress to call a convention only on application of two thirds of the states. Id at 258-61. Formal applications of the Virginia and New York legislatures seeking a second convention are reprinted in Veit, Creating the Bill of Rights at 235, 237 (cited in note 353 ).

48 See 1 Annals at 451-53; Veit, Creating the Bill of Rights at xiv (cited in note 353); id at 250 (Letter of James Madison to Edmund Randolph, June 15, 1789). Antifederalists recognized that this strategy took much of the wind out of their sails and diminished the chances of structural alterations. See, for example, id at 248-49 (Letter of William Grayson to Patrick Henry, June 12, 1789); Kenneth R. Bowling, "A Tub to the Whale": The Founding Fathers and Adoption of the Federal Bill of Rights, $8 \mathrm{~J}$ Early Republic 223, 224 (1988).

49 See 1 Stat 97 . The reason for requiring that an election intervene before a salary raise took effect seems to have been to prevent the members from lining their own pockets. Vining put it somewhat obliquely by referring to the "disagreeable sensation, occa- 
mental authority derived from the people, a guarantee that no branch would exercise powers granted to another, and a jurisdictional amount for appeals to the Supreme Court all died in Congress, as did others discussed in more detail below. ${ }^{450}$ More radical amendments proposed by other members of the House got nowhere at all; in the 1788 elections, which were something of a referendum on the Constitution, Antifederalists had won only 10 of 59 seats in the House, and only Virginia had sent Antifederalists to the Senate. ${ }^{451}$

sioned by leaving it in the breast of any man to set a value on his own work." See 1 Annals at 756-57. Compare US Const, Art I, $\S 6$, cl 2, which makes members of Congress ineligible for appointment to offices created or made more lucrative during their term. The argument for requiring that the number of Representatives initially equal one for every 30,000 inhabitants (instead of simply not exceeding that number, as provided in Art I, § 2) was that a larger House was more democratic; the counterargument was that it was unwieldy, unqualified, and costly. See 1 Annals at 747-56.

After languishing unratified for nearly two centuries, the proposed amendment respecting congressional salaries was rediscovered and reintroduced in state legislatures across the country. Michigan became the 38 th state to approve the proposal on May 7 , 1992, the Archivist certified it as the Twenty-Seventh Amendment, and Congress cravenly passed a resolution declaring it the law of the land. See Twenty-Seventh Amendment to the Constitution, HR Con Res 320, 102d Cong, 2d Sess, in 138 Cong Rec H 3505-06 (May 18, 1992); S Con Res 120, 102d Cong, 2d Sess, in 138 Cong Rec 56948-57001 (May 20, 1992). See also Richard L. Berke, 1789 Amendment is Ratified But Now the Debate Begins, NY Times A1 (May 8, 1992); Richard L. Berke, Congress Backs 27th Amendment, NY Times A26 (May 21, 1992).

In upholding the power of Congress to limit the time for ratification of a proposed amendment in 1921, the Supreme Court soundly concluded that the three-fourths requirement of Article $\mathrm{V}$ implied that ratification by the various states "must be sufficiently contemporaneous ... to reflect the will of the people in all sections at relatively the same period." Dillon v Gloss, 256 US 368, 375 (1921). In 1939, alas, the Court added that whether a proposed amendment (like any other offer) expired within a reasonable time in the absence of an explicit limitation was a nonjusticiable "political" question. Coleman $v$ Miller, 307 US 433, 452 (1939). The upshot may be that the Amendment is not law but that no court is in a position to say so, or that Congress's unfounded declaration will be treated as final.

150 The principal objection voiced to amending the Preamble to affirm popular sovereignty was that the same idea was already expressed in the introductory phrase "We, the people." 1 Annals at 734,745-47. Sherman objected to the proposal to reaffirm the Constitution's own version of separation of powers on the reasonable ground that it was already implicit, Livermore on the bizarre ground that it would be "subversive of the constitution." Id at 789. Madison defended the jurisdictional amount to prevent inconvenience to litigants; Benson wisely objected that small cases might involve important questions. Id at 784. The first of these proposals failed to obtain the requisite two-thirds majority in the House; the other two were excised by the Senate. See id at 795; 4 Doc Hist at 38-39.

${ }^{451}$ Veit, Creating the Bill of Rights at xi-xii (cited in note 353). See, for example, the long list of proposals by Representative Tucker, 1 Annals at 790-92, ranging from limiting the terms of federal officeholders and abolishing most lower federal courts to imposing additional restrictions on direct taxes and repealing Congress's power to regulate its own elections. For a powerful response to the recently resuscitated suggestion of term limits, 
Unlike the English Bill of Rights, Madison insisted, the amendments he proposed would limit the power of the legislature, which was the strongest and most dangerous branch of our federal government. While "paper barriers" could not provide foolproof protection against the abuse of power, they would tend both "to impress some degree of respect" and to "rouse the attention of the whole community," and as Jefferson noted, they would be enforceable by the courts. ${ }^{452}$

To the argument that a Bill of Rights was unnecessary because the central government was one of enumerated powers, Madison responded prophetically that much might be found implicit that was not obvious from the face of the enumeration. ${ }^{453}$ To the argument that a Bill of Rights was dangerous because it might "disparage" other rights by implying "that those rights which were not singled out, were intended to be assigned into the hands of the General Government," he responded with what became the Ninth Amendment. ${ }^{454}$ Thus in the words of its author this amendment was designed not as a limitation on powers previously granted to the federal government but as a principle of interpretation: Despite Hamilton's fears, the prohibition of laws abridging freedom of the press was not to be taken to imply that Congress had any power over the press at all. ${ }^{455}$

see the article published by Roger Sherman under the pseudonym "A Citizen of New Haven" in the New York Packet (Mar 24, 1789), in Veit, Creating the Bill of Rights at 22021, arguing, among other things, that term limits would deprive the nation of its best qualified servants and "abridge the liberty of the people."

452 1 Annals at 453-57. See also Veit, Creating the Bill of Rights at 218 (Letter of Thomas Jefferson to James Madison, Mar 15, 1789) (arguing that one of the principal arguments for a Bill of Rights was "the legal check which it puts into the hands of the judiciary"). Madison also foreshadowed the additional check on congressional usurpation later asserted in the Virginia and Kentucky Resolutions: "[T] he state legislatures will jealously and closely watch the operation of this Government, and be able to resist with more effect every assumption of power.... 1 Annals at 457. See also Brant, James Madison at 267 (cited in note 13).

${ }^{433} 1$ Annals at 455-56 (arguing by way of example that general warrants might be found necessary and proper to the collection of revenue).

ust See id at 456; 4 Doc Hist at 11.

435 This history also helps to clarify the relation between the Ninth Amendment and the Tenth. Madison himself explained the former "as guarding against a latitude of interpretation" and the latter "as excluding every source of power not within the Constitution itself." 2 Annals at 1951. See also Miller, The Federalist Era at 23 (cited in note 7). Arguing that the Tenth Amendment was salutary though redundant, 1 Annals at 458.59, Madison sensibly opposed Tucker's motion to restore the phrasing of the Articles of Confederation, which had reserved to the states all powers not "expressly" granted to the central authority: "[T] here must necessarily be admitted powers by implication, unless the constitution descended to recount every minutia." Id at 790. 
Given the importance of the Bill of Rights today, there was surprisingly little recorded debate on its provisions; but it should be recalled that the First Congress had plenty of other important things to do. Of greatest interest for present purposes were the House proceedings bearing on the religion and speech provisions eventually embodied in the First Amendment.

As initially presented to the Committee of the Whole, the proposal would have provided that "no religion shall be established by law, nor shall the equal rights of conscience be infringed." ${ }^{\prime 456}$ What this meant, as Madison understood it, was "that Congress should not establish a religion, and enforce the legal observation of it by law, nor compel men to worship God in any manner contrary to their conscience." ${ }^{347}$ The whole purpose of the proposal, he later added, was to quiet fears that "one sect might obtain a pre-eminence, or two combine together, and establish a religion to which they would compel others to conform." 458

There was nothing either in the text of the provision as it then stood-and the language ultimately adopted was similar-or in Madison's explanation of its meaning to suggest either that it forbade Congress to provide impartial support to religion in general or that it entitled those with religious scruples to exemptions from generally applicable laws. The conclusion that the Amendment did not require religious exemptions appeared to be confirmed when Congress rejected a proposal that would have explicitly provided that "no person religiously scrupulous sh[ould] be compelled to bear arms." ${ }^{459}$ Adoption of the Tenth Amendment demonstrated that Congress was not reluctant to say the same thing twice in the interest of avoiding misunderstanding. ${ }^{460}$ Yet the principal argument against the exemption for conscientious objectors was that the matter should be "left to the discretion of the Government," 461 and that argument presupposed that the religion clauses themselves did not take the issue out of the legislature's hands.

456 1 Annals at 757. Madison's original proposition was similar except that it forbade establishment of any "national" religion, guaranteed "full" as well as equal rights of conscience, and added that "[t]he civil rights of none shall be abridged on account of religious belief or worship." See 4 Doc Hist at 10 .

4571 Annals at 758.

458 Id.

459 Id at 778. This proposal, approved by the House in slightly amended form, was removed in the Senate. See 4 Doc Hist at 36-37 n 13.

460 See note 455.

461 See 1 Annals at 779-80 (Rep Benson). 
Like the Amendment finally adopted, the version debated in the Committee of the Whole protected not only freedom of speech and of the press but the right of assembly and petition as well. ${ }^{462}$ Sedgwick objected to the inclusion of assembly. "If people freely converse together, they must assemble for that purpose"; one might as well declare "that a man should have a right to wear his hat if he pleased, ... get up when he pleased, and go to bed when he thought proper"; it was unnecessary to make provision for such "trifles... in a Government where none of them were intended to be infringed." ${ }^{463}$

Sedgwick's motion to omit the reference to assembly failed, but his explanation raised several interesting points about the proper scope of a Bill of Rights. Taken out of context, his characterization of assembly as a "trifle" seems to suggest he thought it unimportant. A little reflection may indicate that neither the right to assemble to discuss public issues nor the other rights that Sedgwick so disparagingly invoked could properly be regarded as trivial in that sense. ${ }^{464} \mathrm{He}$ seems to have been making two distinct arguments: that the right of assembly was not likely to be infringed, and that it was implicit in the right to speak. Page was right to warn that experience afforded reason for doubt as to the former conclusion, and Congress was no doubt wise not to leave the latter to the vagaries of litigation. Yet a swarm of modern Supreme Court decisions have confirmed Sedgwick's basic insight that freedom of expression, like the grants of specific powers to Congress, carries with it whatever is necessary to make the provision itself a reality. ${ }^{465}$

The final point to be made about Congress's proposal of the Bill of Rights is a broader one. Except for the First and Seventh amendments, all provisions of the Bill as adopted are phrased in general terms that on their face seem equally applicable to both federal and state authorities. This was equally true of the religion, speech, and jury provisions as they were presented to the

462 Id at 759.

${ }^{63}$ Id at 759-60.

464 On assembly, see Edwards v South Carolina, 372 US 229, 235-38 (1963) (upholding the right to engage in peaceful demonstrations against government policy); on the right not to remove one's hat, see West Virginia State Board of Education v Barnette, 319 US 624, $633 \mathrm{n} 13$ (1943) (invoking the famous cases of William Tell and William Penn).

${ }^{465}$ NAACP v Alabama, 357 US 449, 460-63 (1958) (rights of association and anonymity); Barnette, 319 US at 634-35 (right not to speak); NAACP v Button, 371 US 415, 429 (1963) (right to litigate); Buckley $v$ Valeo, 424 US 1, 39 (1976) (right to spend money in support of candidates); Richmond Newspapers, Inc. $v$ Virginia, 448 US 555, 575-80 (1980) (right of access to criminal trial). See also The Second Century at 382, 318, 421, 510, 525. 
House. ${ }^{466}$ Yet it was abundantly clear from the outset that none of these provisions was meant to limit the actions of state governments. What the state ratifying conventions had sought was assurance that the new central government would not have too much power; they were not asking Congress to protect them against their own state officials. ${ }^{467}$

Most of the provisions that found their way into the Bill of Rights were initially proposed as amendments to Article I, § 9, which a comparison with the following section shows limited only federal authority. The rest were proposed as amendments to Article III, which defines the federal judicial power. ${ }^{468}$ The decision to propose the amendments as separate articles, while hotly controverted, was based on stylistic rather than substantive considerations. ${ }^{469}$ Moreover, in dispatching the final draft to the states, Congress duly recited that it did so in response to the desires of the states "at the time of their adopting the Constitution ... to prevent misconstruction or abuse of its powers." ${ }^{\text {470 }}$

Finally, both Madison's proposal of a separate amendment to protect expression, religion, and jury trial against state action and its rejection by the Senate tend to corroborate the conclusion that none of the Bill of Rights provisions actually adopted limited state action. ${ }^{471}$ For in supporting the proposal its sponsor made clear that he thought state action would not be limited without $\mathrm{it}^{472}$ while the sole argument against his suggestion was that it would be "much better ... to leave the State Governments to themselves." 773

Significantly, the amendments Congress proposed were sent to the states for ratification without presidential approval, despite the Article I, $\S 7$ requirement that the President be given the opportunity to veto not only bills but also (with the exception of adjournment) every other "order, resolution, or vote, to which

466 See 4 Doc Hist at 10-12; 1 Annals at 757-92.

467 See, for example, Elliot, 2 Debates at 177-78 (Massachusetts), 545-46 (Pennsylvania); 4 Debates at 238-43 (North Carolina) (cited in note 426).

${ }_{468}$ See 4 Doc Hist at 10-11. Compare US Const, Art I, § 9, cl 3 ("No bill of attainder or ex post facto law shall be passed."), with Art I, § 10, cl I ("No State shall . . . pass any bill of attainder [or] ex post facto law ....").

459 See 1 Annals at 734-44, 795.

4701 Stat 97 (Sept 1789).

${ }^{471}$ See 4 Doc Hist at 11, 39; Barron v Mayor of Baltimore, 32 US 243, 247 (1833); The First Hundred Years at 189-93.

${ }^{772}$ See 1 Annals at 784 (Rep Madison) ("If there was any reason to restrain the Government of the United States from infringing upon these essential rights, it was equally necessary that they should be secured against the State Governments.").

473 Id at 783 (Rep Tucker). 
the concurrence of the Senate and House of Representatives may be necessary." ${ }^{\text {"74 }}$ The Annals reveal no discussion of this important question. Yet the action of the First Congress was cited to the Supreme Court as a precedent when it upheld the Eleventh Amendment against the contention that it should have been submitted to the President for his approval, and the precedent has been followed with rare exceptions ever since. ${ }^{475}$

\section{CONCLUSION}

It should be plain from this lengthy summary that both the first President and the First Congress took the Constitution very seriously. Washington set the tone in his inaugural address by referring Congress to "the great, constitutional charter ... which, in defining your powers, designates the objects to which your attention is to be given." ${ }^{376}$ Members of Congress repeatedly acknowledged their obligation to respect constitutional limitations on their powers. "Let us examine the Constitution," said Fisher Ames during the bank debate, "and if that forbids our proceeding, we must reject the bill ...."477 Boudinot agreed, adding that "[w]hatever power is exercised by Congress must be drawn from the Constitution." ${ }^{478}$ Thus the First Congress and the President contributed significantly to our understanding of the Constitution as supreme law of the land.

Respect for the Constitution during the First Congress went beyond ritualistic acknowledgement of its authority; a remarkable proportion of the debate centered on the task of determining its meaning. At the outset Madison admonished the House, as Washington had admonished him, that constitutional issues should be given "careful investigation and full discussion" because "[t]he decision that is at this time made, will become the permanent exposition of the constitution." ${ }^{379}$ Constitutional

${ }^{474}$ See Hollingsworth $v$ Virginia, 3 US 378, 380 (1798). Neither Congress's resolution, 1 Annals at 948 , nor Washington's letter of transmittal to the states, 30 Writings of Washington at 426 (cited in note 10), said anything of presidential approval.

475 See Hollingsworth, 3 US at 381; The First Hundred Years at 20-23; Edward Campbell Mason, The Veto Power 117-18 (Russell \& Russell, 1967) (first published 1890).

4761 Annals at 28.

4772 Annals at 1953.

478 Id at 1970. "[H]owever expedient it might be," he insisted, "if it was clearly unconstitutional, the bill should never receive the sanction of the representatives of the people." Id. See also 1 Annals at 479 (Rep Madison) ("I am clearly of opinion with the gentleman from South Carolina, (Mr. Smith) that we ought in this, and every other case, to adhere to the constitution....").

479 Annals at 514. For Washington's earlier letter to Madison, see note 10. 
questions cropped up in the House and Senate every time somebody sneezed, and one proposal after another was subjected to intensive debate to determine its compatibility with relevant constitutional provisions. Members of Congress plainly thought it necessary to demonstrate that the Constitution supported their actions, and thus everything they did as well as everything they said helps to inform our understanding of particular constitutional provisions.

The arguments employed during the First Congress helped also to develop an understanding of the techniques of constitutional interpretation. Most of the tools of construction we recognize today were employed in the debates: text, ${ }^{480}$ structure, ${ }^{481}$ history, ${ }^{482}$ purpose, ${ }^{483}$ practice, ${ }^{484}$ the avoidance of absurd consequences. ${ }^{45}$ Despite the deliberate decision of the Conven-

180 Textual arguments, of course, were legion. One prominent example was Madison's insistence that the bank bill fell within neither the power to tax nor the power to borrow because "[i]t laid no tax" and "does not borrow a shilling." 2 Annals at 1946-47. See also Tucker's powerful argument from the terms of the Patent Clause, 1 Annals at 180, noted in the text accompanying note 134 .

481 See, for example, Madison's argument that the enumeration of federal powers implied that those not listed were reserved to the states. 2 Annals at 1945.

${ }^{482}$ British practice was invoked by Sherman in connection with removal of executive officers, by Lee, Page, and White in connection with unfinished business, and by Page again (without invoking the Constitution) in connection with the right to counsel in an election contest. See 1 Annals at 510-11 (Rep Sherman), 1084-85 (Reps Lee, Page, and White), 667 (Rep Page). Both sides drew on the Articles of Confederation during the bank debate. Laurance noted that the Continental Congress had chartered a bank, Boudinot that in accepting the Northwest Territory it had exercised implied powers. Madison responded that Congress had known it had no authority to establish banks and that the General Welfare Clause meant no more than its counterpart in the Articles. 2 Annals at 1941 (Rep Laurance), 1946-47 (Rep Madison), 1975 (Rep Boudinot).

483 See 2 Annals at 2002 (Rep Gerry, quoting Blackstone) ("[T]he most universal and effectual way of discovering the true meaning of a law, when the words are dubious, is by considering the reason and spirit of it, or the cause which moved the Legislature to enact it.").

184 "If Congress may not make laws conformably to the powers plainly implied, though not expressed in the frame of Government, it is rather late in the day to adopt it as a principle of conduct." Id at 1954 (Rep Ames) (citing the taxation of ships, the erection of lighthouses, and the regulation of seamen under the Commerce Clause as precedents for establishing a national bank). See also id at 2003 (Rep Gerry) ("Does the gentleman conceive that such [powers] only are delegated as are expressed? If so, he must admit that our whole code of laws is unconstitutional.").

485 "Where a meaning is clear," said Madison, "the consequences, whatever they may be, are to be admitted-where doubtful, it is fairly triable by its consequences." Id at 1946. To read the General Welfare Clause broadly enough to justify establishing a bank, he argued, "would give to Congress an unlimited power" and "render nugatory the enumeration of particular powers." Id. See also Jefferson's prophetic argument against the bank, 19 Jefferson Papers at 276 (cited in note 12) ("He who erects a bank creates a subject of commerce in it's bills; so does he who makes a bushel of wheat, or digs a dollar out of the mines. Yet neither of these persons regulates commerce thereby."). Compare 
tion not to publish an official record of its proceedings, ${ }^{486}$ various members invoked their recollection of events at Philadelphia to illuminate the meaning of particular provisions; ${ }^{487}$ they were met with very modern arguments for ignoring them. ${ }^{488}$

The quality of the constitutional debates in the First Congress was impressively high. To begin with, the members exhibited an intimate knowledge of what the Constitution actually said. One has the impression they must have had copies of the document at their elbows at all times. Moreover, they had obviously devoted considerable effort to trying to figure out what its various provisions might mean. In the great controversies over removal of cabinet officers and incorporation of the bank, for example, the House debates brought forth virtually all the constitutional arguments that anyone has come up with in two centuries of second-guessing ${ }^{489}$-as they did on many other issues of greater or lesser importance which as a practical matter they settled for all time.

The debates in the first House were conducted in the main by a strikingly small number of Representatives. Elbridge Gerry, respected by both Jefferson and John Adams, spoke more often during the first session than anyone but Madison. ${ }^{400}$ Ames and Sedgwick of Massachusetts, Boudinot of New Jersey, Smith and Tucker of South Carolina were reliably impressive. ${ }^{41}$ Benson,

Wickard v Filburn, 317 US 111 (1942).

486 Farrand, 2 Convention Records at 648 (cited in note 35).

487 See, for example, 1 Annals at 578-79 (Rep Baldwin) (standing in opposition to "mingling the powers of the President and Senate"); 2 Annals at 1409-10, 1591 (Gerry and Madison on assumption of state debts), 1604 (Sherman on a national university), 1945 (Madison on the power of incorporation). Similarly, during the debate over presidential removal, Jackson invoked James Wilson's argument in the Pennsylvania ratifying convention that the Senate was to serve as a check on the President, and Smith quoted at some length from the Federalist Papers-which Jackson and Boudinot also cited on opposite sides of the bank controversy. 1 Annals at 577-78 (Rep Jackson), 474 (Rep Smith); 2 Annals at 1941 (Rep Jackson), 1977 (Rep Boudinot). "In controverted cases," said Madison, "the meaning of the parties to the instrument" was "a proper guide" to its interpretation, and "[c]ontemporary and concurrent expositions are a reasonable evidence of the meaning of the parties." Id at 1946.

${ }^{488}$ See 2 Annals at 2004-05 (Rep Gerry) (adding similar objections to reliance on the incomplete records of state ratifying conventions).

${ }^{400}$ Myers $v$ United States, 272 US 52 (1926) (removal); The Second Century at 193-95; M'Culloch v Maryland, 17 US 316 (1819) (bank); The First Hundred Years at 160-68.

400 See George Athan Billias, Elbridge Gerry: Founding Father and Republican Statesman 1, 225 (McGraw-Hill, 1976), citing Brant, James Madison at 246 (cited in note 13). His efforts, however, were not universally admired. "Gerry took up the Time of the Committee to the hour of adjournment," wrote Maclay after a visit to the House. "[H]e is a tedious \& most disagreeable Speaker." 9 Doc Hist at 233.

492 See, for example, 1 Annals at 492-96, 559-64; 2 Annals at 1952-60 (Ames on 
Clymer, Fitzsimons, Laurance, Page, Scott, Sherman, Vining, and a few others made significant or frequent contributions. ${ }^{492}$ If the record is a fair sample of the whole work of the First Congress, roughly half the members of the House essentially said nothing at all. ${ }^{493}$

But the man who dominated constitutional debate in the first House of Representatives was the man who had dominated the Constitutional Convention itself, James Madison. Time and again, after other members had haggled inconclusively over an important issue of constitutional interpretation, Madison would step in and make everything clear. It was he who made the

removal and the Bank); 1 Annals at 1142-43; 2 Annals at 1960-65 (Sedgwick on export regulations and the Bank); 1 Annals at 390-91; 2 Annals at 1970-79 (Boudinot on removal and the Bank); 1 Annals at 828-32 (Smith on inferior federal courts); 1 Annals at 180 (Tucker on the Patent Clause). Boudinot's biographer, conceding that he lacked the originality of Hamilton or Madison, concluded that he "had ranked among the leaders" of the First Congress. Boyd, Elias Boudinot at 137, 192 (cited in note 426). For an appreciative assessment of Ames's work in that body, see Winfred E.A. Bernhard, Fisher Ames: Federalist \& Statesman 118, 157 (North Carolina, 1965). See also Richard E. Welch, Jr., Theodore Sedgwick, Federalist: A Political Portrait 77, 106, 251 (Wesleyan, 1965) (finding Sedgwick no great policy maker or statesman but an able legislator and politician who was Hamilton's chief lieutenant in the House); George C. Rogers, Jr., Evolution of a Federalist: William Loughton Smith of Charleston (1758-1812) 208, 219 (South Carolina, 1962) (giving that honor to Smith).

492 The speeches of James Jackson of Georgia, whom Forrest McDonald described as a "fierce, uncouth rustic" who was "surprisingly learned," McDonald, Hamilton at 174 (cited in note 13), were more often remarkable for bluster than for perspicacity. See, for example, his diatribes on the militia bill, Aurora General Advertiser (Dec 24, 1790) (arguing that if conscientious objectors were exempted from service "he did not despair of seeing the whole nation turn quakers" and "quakerism" become the established religion), on the whiskey excise, 2 Annals at 1890-91 (foreseeing a time "when a shirt shall not be washed without an excise" and suggesting that Congress might just as well "pass a law interdicting the use of ketchup, because some ignorant persons had been poisoned by eating mushrooms"), and on the bank, id at 1967-70 (objecting to borrowing generally and insisting that Art IV gave Congress authority only with respect to "property already belonging to the United States").

${ }^{493}$ Madison had predicted this, noting on his way to the first session that the roster of members contained "a very scanty proportion who will share in the drudgery of business." Letter to Edmund Randolph, Mar 1, 1789, in 11 Madison Papers at 453 (cited in note 1). Efforts to identify the most insignificant Member must await investigation of subsequent Congresses. As a preliminary matter one may safely hazard the conclusion that such members as Benjamin Contee, William Floyd, Abiel Foster, Samuel Griffin, Jonathan Grout, Daniel Hiester, Jr., Daniel Huger, George Mathews, Peter Muhlenberg, George Partridge, James Schureman, Thomas Sinnickson, William Smith of Maryland, Jonathan Sturges, Jeremiah Van Rensselaer, and Henry Wynkoop, see 9 Doc Hist at xxxi-xxxii, maintained an impressively low profile during the First Congress, since few of them are recorded as ever having opened their mouths. "The way in Which this good Man, can best serve his country," said Maclay of Wynkoop, "is in superintending his farm." 9 Doc Hist at 233. Compare David P. Currie, The Most Insignificant Justice: A Preliminary Inquiry, 50 U Chi L Rev 466 (1983). 
strongest and most careful arguments for presidential removal and against the national bank. ${ }^{494}$ It was he who best expounded the considerations relevant to determining the qualifications of Representatives ${ }^{495}$ and Congress's authority to acquire information. ${ }^{496}$ It was he who took the lead in proposing, explaining, and advocating the Bill of Rights. ${ }^{497}$ In the beginning, when he spoke for the administration, Madison tended to prevail. When he deserted the President on assumption of state debts and establishment of the Bank, he ended up with the minority. But he was at all times a potent force in constitutional debate; and thus the Father of the Constitution played a most significant and constructive role in interpreting and revising the document he had had an equally strong hand in composing. ${ }^{498}$

In construing the Constitution to enable it to assume state debts, establish a bank, regulate the labor relations of seamen, and prescribe the oath to be taken by state officers, ${ }^{499}$ the First

194 See 1 Annals at 387, 479-82, 514-21 (removal); 2 Annals at 1944-52 (bank).

4951 Annals at $420-23$.

496 Id at $1115,1145-46$.

497 Id at 448-62. See Veit, Creating the Bill of Rights at xvi (cited in note 353) ("Madison has a greater claim to being known as the father of the Bill of Rights than of the Constitution. Without his commitment there would have been no federal Bill of Rights in $\left.1791 .{ }^{\prime}\right)$.

${ }^{498}$ See McDonald, Washington at 24 (cited in note 13); Ketcham, James Madison at 293 (cited in note 427) (noting that during the first session, "[e]xcept for the judiciary act, fashioned in the Senate, Madison had taken the lead at every stage"); Swanstrom, The Senate at 267 (cited in note 274) (claiming "[t]he leading Member of the First Congress was, by all odds, James Madison"). Because of the secrecy of Senate proceedings, we have less knowledge of the performance of individual Senators. One observer tells us that the "outstanding leaders" were Ellsworth, King, Philip Schuyler, and Caleb Strong, and that Monroe joined them among the ten or so members who did most of the committee work after his selection to fill an unexpired term in 1790. Harry Ammon, James Monroe: The Quest for National Identity 83 (McGraw-Hill, 1971). See also Swanstrom, The Senate at 230-32 ("In session after session a handful of Senators bore the major share of the burden of committee work while others were apparently content merely to attend sessions and vote."); id at 268-69 (noting that "[t]he initiative was taken by Oliver Ellsworth ... who during his 7 years in the Senate assumed more responsibility, did more work, and exerted more practical leadership in the day-by-day activities of the upper Chamber than any other Member of that body").

If Madison and Ellsworth were de facto leaders of the House and Senate, their talents and industry were at least equalled by those of Hamilton and Jefferson in the Cabinet, as evidenced by the former's impressive reports respecting financial matters and the latter's on weights and measures-all prepared by the Secretaries themselves while attending to the daily responsibilities of office. See id at 269-70 (adding that "the impetus behind the major legislative program during Washington's administration did not come from either Madison or Ellsworth—or any other Member of Congress-but from Alexander Hamilton").

4991 Stat 23 (June 1, 1789). The debates on this provision are discussed in the parallel study of structural issues confronting the First Congress. See note 14. 
Congress took a broad though certainly plausible view of its powers. On the other hand, it resisted proposals to do a number of things that might have seemed desirable when substantial constitutional doubts were raised-such as financing an expedition to Baffin's Bay or creating a national university. ${ }^{500}$ There were policy as well as constitutional arguments against these initiatives, and the latter was postponed rather than rejected. Thus it cannot be said that Congress disapproved them on constitutional grounds; but the tone of the discussion suggests that Congress was sincerely concerned not to do anything it was unauthorized to do.

Repeatedly and without contradiction, members of the First Congress acknowledged that the constitutionality of their actions would be subject to judicial review. "It is said," remarked Laurance during the bank debate, "we must not pass a problematical bill, which is liable to a supervision by the Judges of the Supreme Court; but he conceived there was no force in this, as those Judges are invested by the Constitution with a power to pass their judgment on all laws that may be passed."501 Boudinot added that " $\mathrm{h}] \mathrm{l}$ was so far from controverting this right in the Judiciary, that it was his boast and his confidence .... [ []t was the glory of the Constitution that there was a remedy even for the failures of the supreme Legislature itself." 502 "[T]ndependent tribunals of justice," said Madison in introducing the Bill of Rights, "will consider themselves in a peculiar manner the guardians of those rights; they will be an impenetrable bulwark against every assumption of power in the legislative or executive ....".503

${ }^{500}$ Similarly, the House decided not to specify the number of commissioners to be appointed to treat with the Southern Indians once it was suggested that the Constitution left the matter to the discretion of the President and Senate. 1 Annals at 716-30.

${ }^{501} 2$ Annals at 1966.

502 Id at 1978-79. See also id at 1988 (Rep Smith) (arguing that legislators had to determine in the first instance whether the bank was constitutional but that "it was still within the province of the Judiciary to annul the law, if it should be by them deemed not to result by fair construction from the powers vested by the Constitution").

${ }^{503} 1$ Annals at 457. Benson echoed this understanding in arguing against a constitutional exemption of conscientious objectors from military service: "If this stands part of the constitution, it will be a question before the Judiciary on every regulation you make with respect to the organization of the militia, whether it comports with this declaration or not." Id at 780. Far from denying the right of judicial review, opponents of presidential authority to remove executive officers tended to argue that the judiciary played a special role in constitutional interpretation. Thus Representative Smith branded a legislative declaration that the Secretary of Foreign Affairs was "removable from office by the President," id at 473, "an infringement of the powers of the Judiciary." Id at 488-89. See also id 
These unchallenged acknowledgements of judicial review are significant not only because they cast light upon contemporaneous understanding of the Constitution but also because they demonstrate the willingness of Congress to accept meaningful limitations on its powers. At the same time, by taking constitutional limitations seriously, Congress earned respect for its opinion as to their meaning. While not conclusive, congressional interpretation of the Constitution has traditionally and justly been accorded considerable deference by courts as well as by other organs of government. ${ }^{504}$ Nearly all of the constitutional interpretations of the First Congress that have been tested in the courts have been sustained. ${ }^{505}$

Legal realists and their successors will remind us that, human nature being what it is, legislators are at least as likely as judges to deduce their reasons from the conclusions they are alleged to support. ${ }^{506}$ Members of the First Congress were not

at 491-92 (Rep Gerry) (arguing that if the President and Senate "do not understand the constitution" the question should be left to "the proper tribunal; the judges are the constitutional umpires on such questions"). Proponents of such a declaration responded not by denying judicial authority but by reaffirming it. "If we declare justly on this point," said Ames, "it will serve for a rule of conduct to the Executive Magistrate; if we declare improperly, the judiciary will revise our decision .... Id at 496. See also id at 520 (Rep Madison) (insisting that both Congress and the courts were empowered to interpret the Constitution); id at 582 (Rep Baldwin). Representative White, who thought the President and Senate should be left to determine the relation between their respective powers subject to judicial review, opined that "the Legislature may construe the constitution with respect to the powers annexed to their department, but subject to the decision of the judges." Id at 539. For Gerry's unchallenged view that federal courts would also strike down unconstitutional state laws, see id at 278.

sos See, for example, the emphasis placed on congressional understanding and practice in such cases as Martin v Hunter's Lessee, 14 US 304, 378-79 (1816), discussed in The First Hundred Years at 91-96; M'Culloch, 17 US at 422-23, discusssed in The First Hundred Years at 160-68; and Field $v$ Clark, 143 US 649, 672-73 (1892), discussed in The Second Century at 16. See also Justice Frankfurter's famous reference to the "gloss" placed on the Constitution by legislative and executive actions in Youngstown Sheet \& Tube Co. v Sawyer, 343 US 579, 610-11 (1952) (concurrence), discussed in The Second Century at 365-69.

s0s Famous examples include Hunter's Lessee, 14 US 304 (review of state court judgments); M'Culloch, 17 US 316 (Bank of the United States); and Gibbons, 22 US 1 (ship licensing). See The First Hundred Years at 91-96, 160-68, 168-76. The best known apparent exception is the mandamus provision struck down in Marbury $v$ Madison, 5 US 137, 171-79 (1803), but it seems probable that the Court had to misinterpret the statute in order to hold it unconstitutional. See The First Hundred Years at 67-68. See also Mossman $v$ Higginson, 4 US 12 (1800); The First Hundred Years at 29-30; and Hodgson $v$ Bowerbank, 9 US 303 (1809); The First Hundred Years at 89-90 (giving Congress the benefit of the doubt in construing a provision for federal jurisdiction in cases involving aliens not to go beyond the limitations of Article III).

${ }^{506}$ During the bank debate Gerry argued that the rules of interpretation Madison had espoused were "the result of his interpretation, and not his interpretation of the rules." 2 
wholly disinterested interpreters of the Constitution. Each had a political philosophy of his own; each had constituents to represent. ${ }^{507}$ Moreover, in most instances the members were passing on the extent of their own powers. It is because nobody can be trusted to do that impartially that we have given judges power to review the constitutionality of acts of Congress. ${ }^{508}$

Yet legal realism has not prevented us from taking the reasoning of judges seriously or from evaluating it on its own merits. Nor is it true that legislators, any more than judges, always consult only their own preferences or self-interest; there are plenty of examples of public officials who take seriously their oath to support the Constitution. Washington thought a national bank would be good for the country, but he was prepared to veto it until Hamilton persuaded him that it was constitutional. ${ }^{509}$ Aedanus Burke thought lower federal courts would make the people "insecure in their liberties and property" but conceded that he could see no "substitute . . . that was not contrary to the constitution." ${ }^{210}$ Recognition that legislators' arguments are frequently influenced by interested motives does not require that we simply dismiss them as partisan rhetoric-any more than we do the arguments of equally human and often equally interested judges. ${ }^{111}$

In short, not only the debates but also the actions taken or rejected by the First Congress constitute a practical interpretation of the Constitution by able and diligent officers sworn to support it and charged with the responsibility to put it into practice. The legislative interpretation was not binding. It was not

Annals at 1998.

${ }^{507}$ The vote on such questions as slavery, the tax on spirits, and the location of the capital was essentially sectional, while "the attitude of the members of Congress toward the assumption of state debts was [generally] determined by the size of the debt of the state they represented." Miller, The Federalist Era at 46 (cited in note 7). Representatives like Ames, Benson, Boudinot, Laurance, Sedgwick, and Vining tended to favor a strong central government with a strong executive; Giles, Jackson, Livermore, Page, Stone, Tucker, and others tended to take the opposite position. Gerry and Smith opposed presidential removal but supported the bank; Madison's vote was contrary to theirs in both cases. See also George H. Haynes, 2 The Senate of the United States: Its History and Practice 1069 (Houghton Mifflin, 1938) (noting that many Senators often voted "in the closest accordance with their own private and class interests").

${ }^{503}$ See Federalist 78 (Hamilton), in The Federalist Papers at 524 (cited in note 36); Marbury, 5 US at 178.

${ }^{509}$ See text accompanying notes 215-16.

5101 Annals at 844 .

511 "The supposition of universal venality in human nature," wrote Hamilton, "is little less an error in political reasoning than the supposition of universal rectitude." Federalist 76, in The Federalist Papers at 513-14. 
always unanimous. It was not always convincing. It was not always clear that Congress was even aware of the existence of a constitutional problem. Sometimes, like judges, members of Congress must have been advocates for a predetermined position. Even then their arguments were designed to persuade the impartial observer and thus help us to understand the range of interpretations that would have appeared plausible when the Constitution was new.

Moreover, the sophistication and persuasiveness of the arguments in the First Congress was such as to suggest that on the whole the members performed their obligations both capably and conscientiously. Indeed that is putting it mildly. The truth of the matter is that the achievements of the First Congress were on a plane with those of the Convention whose much admired work it was endeavoring to implement.

But the records of the First Congress do more than help to restore one's sometimes shaky faith in the capacity of republican government to act in the public interest. They also afford important evidence of what thoughtful and responsible public servants close to the adoption of the Constitution thought it meant. What they thought is surely of interest not only to historians but also to anyone trying two hundred years later to figure out what the Constitution means. 
- 